\title{
مؤسسات البناء الفكري في ضوء القرآن الكربم
}

\author{
يحيى محمد عامرراشـد \\ جامعة الملك خالد- كلية الشريعة وأصول الدين- قسم القرآن وعلومه- المملكة العربية السعودية \\ yahya19622@gmail.com
}

الملتخص:

اشتمل هذا البحث (مؤسسـات البناء الفكري في ضوء القرآن الكريم)، على مقدمة، وتمهيد، وخمسة مباحث، خاتمة. أما المقدمة، فقد قدمت فهها تصوراً أولياً لطبيعة البحث، وعرضت فيها أسباب اختيار موضهوع البحث، وأهميته، وأهدافه، والمنهج المستخدم في كتابته، ومشكلته، والدراسات السابقة، وخطة البحث.

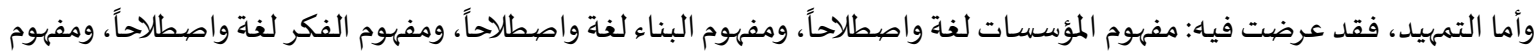
البناء الفكري كمصطلح مركب تركيباً وصفياً.

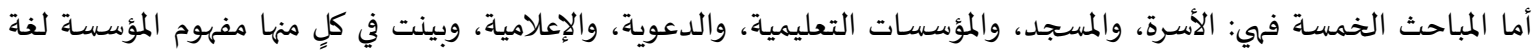
واصطلاحاً، واهتمام القرآن بها وأهميتها في بناء الفكر. وخلصت من هذا كله إلى أن للفكر في الإسلام مؤسسات يجب إنهاء تفعيلها، وأن بناء المسلم بناء فكرياً من أوائل القضاياء-إن لم تكن الأولى التي اهتم بها الإسلام ودعا إليها في أول ما نزل من القرآن على الإطلاق.

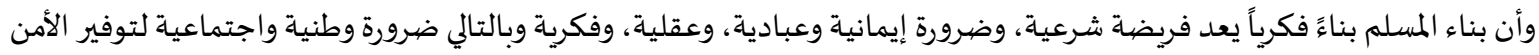

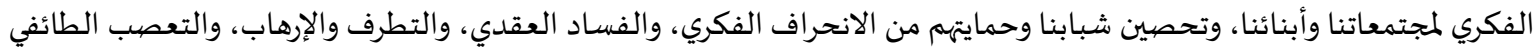

$$
\text { والمناطقي، ومن الغزو الثقافي العارم عموماً. }
$$

الكلمات المفتاحية: مؤسسات البناء الفكري، الحروب الفكرية.

(a) (1)

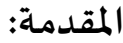

الحمد الله والصلاة والسلام على رسول الله وعلى آله وصحبه ومن والاه... أما بعد فإن الصراع بين الحق والباطل وبين المسلمين وأعدائهم لن يتوقف بل يزداد مع مرور الوقت ضراوةًا ويتسع أفقاً ويتعدد مجالاً ويتنوع

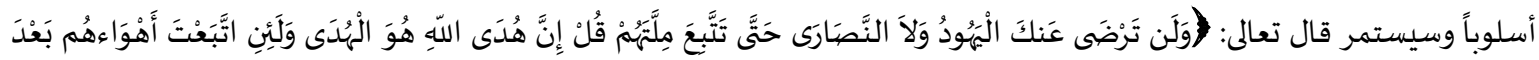

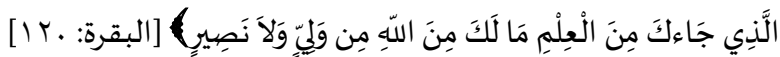

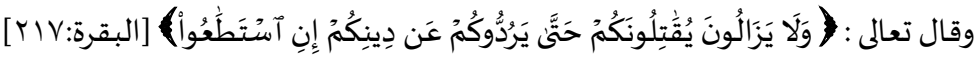

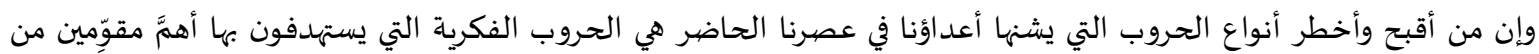
مقومات المجتمعات الإسلامياة:

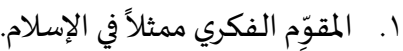

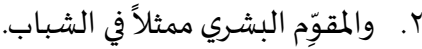

ولهذا أصبح التصدي لهذه الحروب ومواجهتها من أوجب الواجبات ومن أولى الأولويات حفاظاً على الدين من التشويه والتشكيك

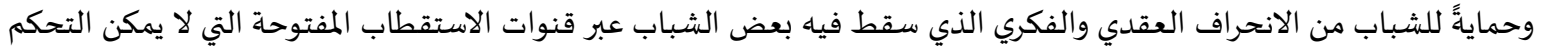
فيها، ومن أخطر مهالك هذا الاستقطاب ومهاوياء: الإلحاد، والرفض، والطائفياة، والتطرف، والإرهاب...

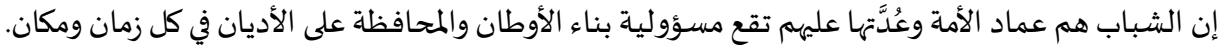

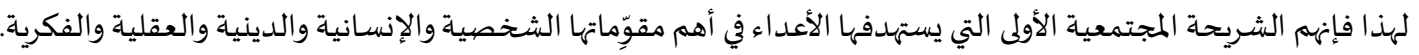


ولهيذا فإن حمايتهم ووقايتهم وتحصينهم من الانحرافات الفكرية والعقدية يجب أن تكون في مقدمة أولوياتنا وعلى رأس اهتماماتنا وفي

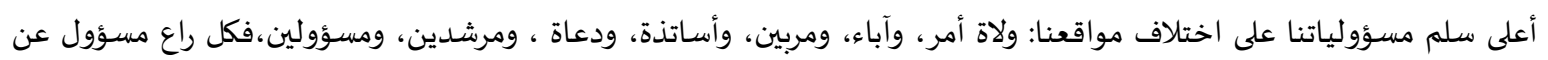

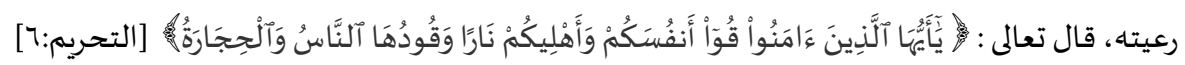

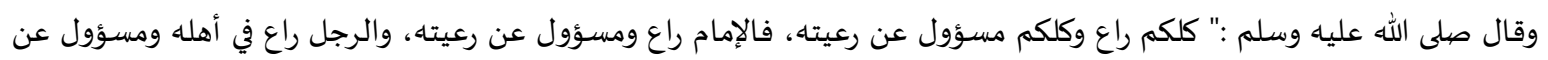

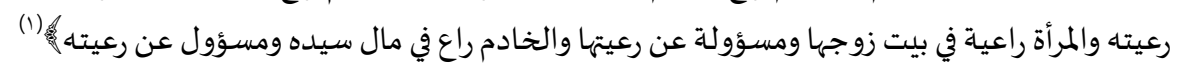

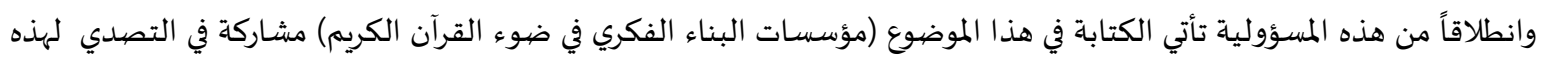

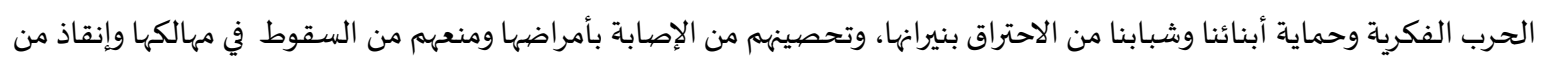

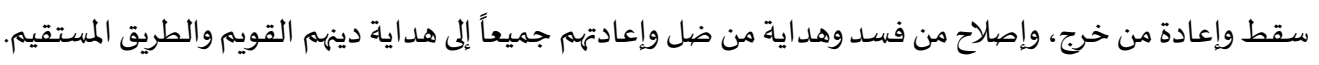

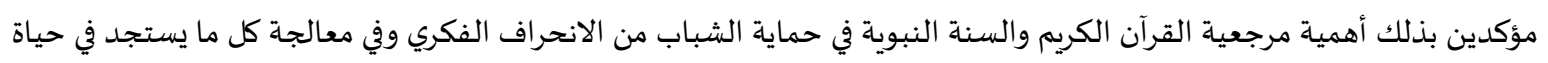

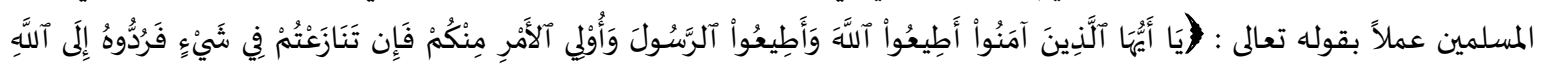

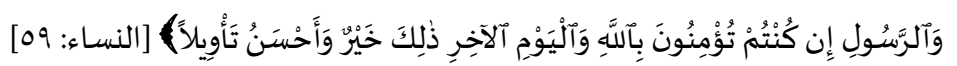

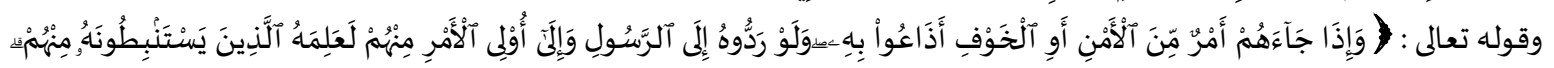

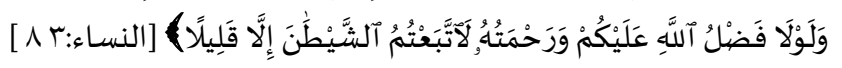

أسباب اختيار موضيوع البحث:

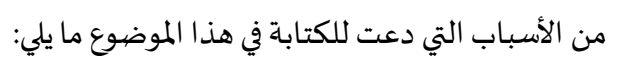

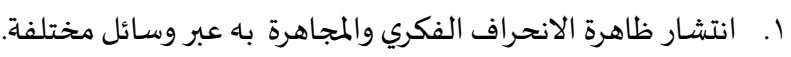

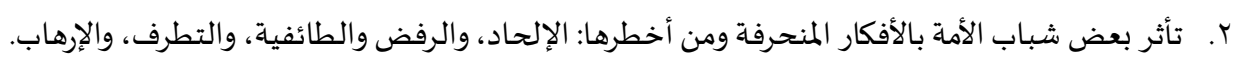

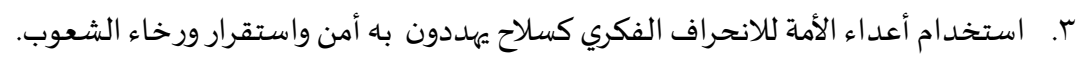
ع. معالجة الجهل وسوء الفهم اللذين أوجدا بيئة قابلة لمثل هذه الأفكار.

\section{أهمية البحث:}

تبرز أهمية البحث في النقاط الآتية:

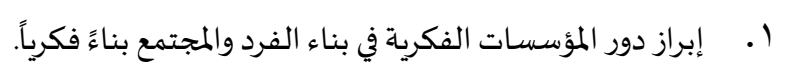
r r . أكيد شمولية القرآن وصلاحيته في كل زمان ومكان.

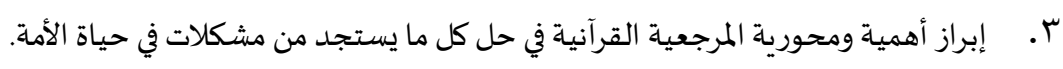
ـ. تقديم بحث علمي يؤصل لمؤسسات البناء الفكري في ضوء القرآن الكريم.

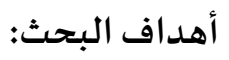

من الأهداف التي يسعى البحث إلى تحقيقها ما يلي:

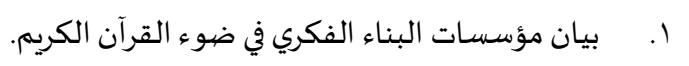

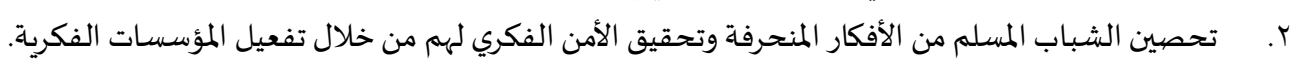

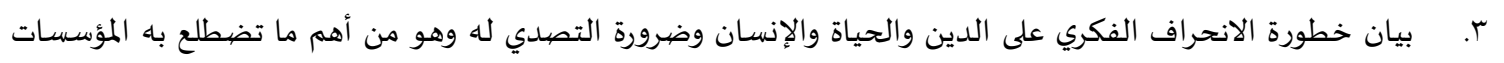
الفكرية. منهج البحث: سوف أستخدم في كتابة هذا البحث المنهج الوصفي التحليلي وذلك من خلال استقراء النصوص القرآنية المتعلقة بمؤسسات البناء الفكري وجمعها جمعاً موضوعياً ثم تحليلها وتوجيهها توجيهاً استدلالياً.

(1) اخرجه البخاري في صحيحه من حديث ابن عمر مرفوعاً ، كتاب الجمعة، باب الحمعة في القرى والمدن، البرقم (بوم) (Y/0) 


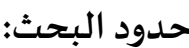

كما هو معلوم من عنوان البحث أن البحث منحصرّ في مؤسسات البناء الفكري في ضوء القرآن الكريم.

مشكلة البحث:

إن بناء الفرد في أي مجتمع من المجتمعات لا يتأتى إلا من خلال مؤسسات تهتم بذلك.

فهل للبناء الفكري في الإسلام مؤسسات ؟

وما هي هذه المؤسسات ؟

وما دورها في تحصين المسلم، وتحقيق الأمن الفكري لله.

هذا ما سيـجيب عليه البحث إن شاء الله تعالى.

الدراسـات السـابقة:

يعد موضوع الفكر من الموضوعات المعاصرة والحديث عناه أصبح حديث الساعة في وسائل الإعلام والتواصل الاجتماعي المختلفة وفي المؤسسات العلمية والبحثية، وقد كتب فيه الكثير من الكتب والأبحاث والمقالات، وعقدات لموضوات له الكثير من الندوات والملتقيات، وكثرت فيه الخطب والمواعظ والإرشادات.

لكنني لم أجد من أفرد هذا الموضوع في بحث مستقل في ضوء المواء القرآن الكريم، وهذه إحدى الصعوبات التي واجهتني في كتابة هذا الموضوع وسوف أحاول أن أفيد مما كتب في الفكر بصورة عامة بما يخدم البحث ويحقق أهد افهـ.

خطة البحث:

يشتمل هذا البحث على مقدمة وتمهيد وخمسة مباحث وخاتمة.

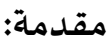

التمهييد: مصطلحات البحث.

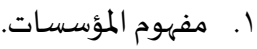

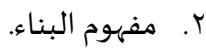

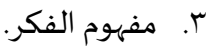

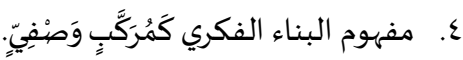

المبحث الأول: الأسرة.

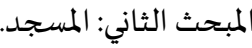

المبحث الثالث: المؤسسـات التعليمية.

المبحث الرابع: المؤسسـات الدعوية.

المبحث الخامس: المؤسسات الإعلامية.

مفهوم المؤسسسات:

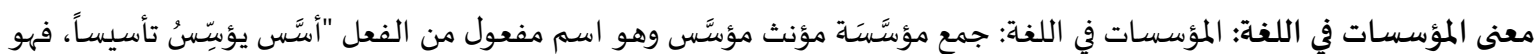

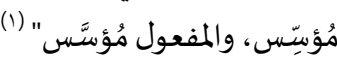

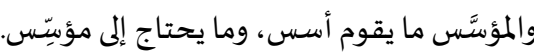

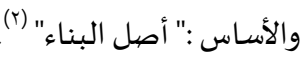

و "الأسـاس: قاعدة البناء التي يقام عليها وأصل كل شيء ومبدؤه" (r).

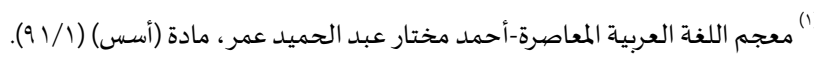

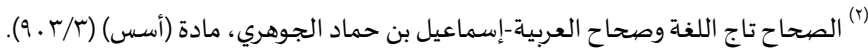

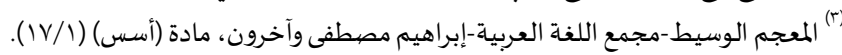

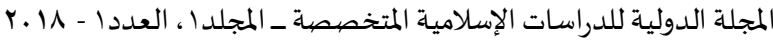


معنى المؤسسـات في الاصطلاح: عرفها جبران مسعود في معجم (الرائد) فقال :"جمعية أو معهد أو شركة أسست لغاية اجتماعية أو

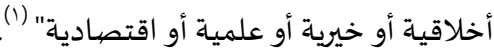

معنى البناء في اللغة: البناء في اللغة: مصددر بنى يبني بناء "ويستعمل مجازاً في معان تدور حول التأسيس والتنمية"|(Y).

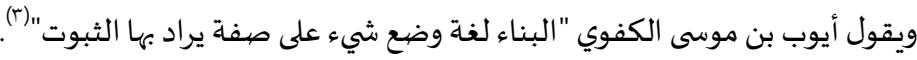

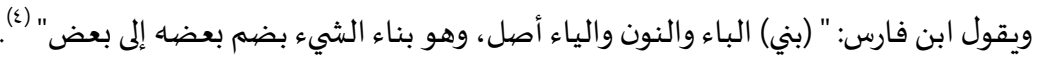

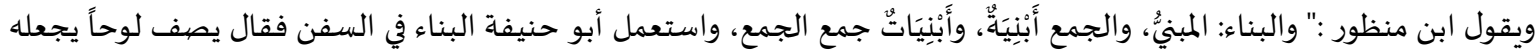

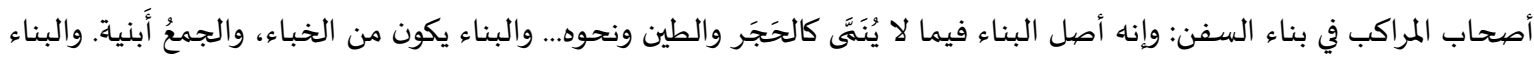

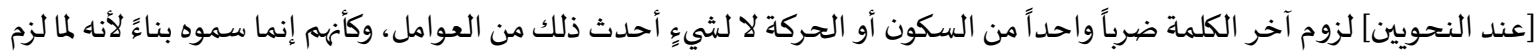

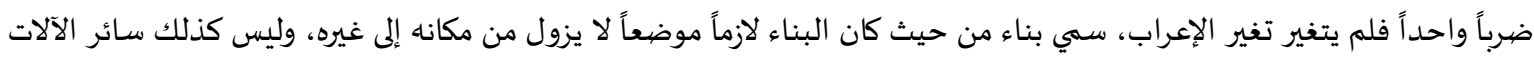

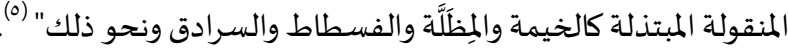
وفي هذا إشـارة إلى معنى الثبات الذي يوحي به لفظذ (البناء).

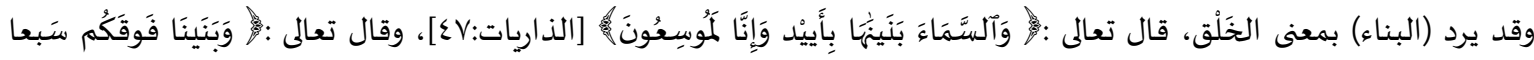

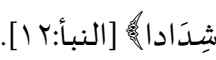
ويقول ابن منظور :"البناء واحد الأبنية، وهي البيوت التي تسكنها الأعراب في الصحراء، فمنها الطِّراف والخباء والبناء والقباُُ والمِضربُ، وفي

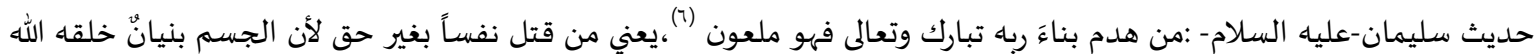
وركَّبَه "(v) معنى البناء في الاصطلاح: البناء في الاصطلاح: عرفه الكفوي_كما سبق_ بأنه "وضع شيء على شيء على صفة يراد بها الثبوت" (^.).

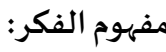

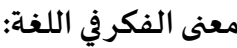

$$
\begin{aligned}
& \text { الفكر في اللغةة: عرف بتعريفات كثيرة منها: }
\end{aligned}
$$

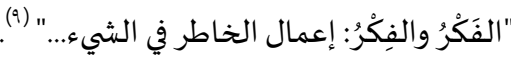

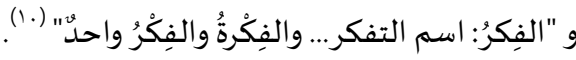

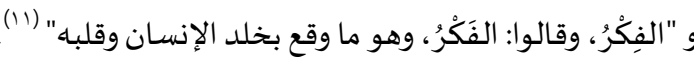

$$
\begin{aligned}
& \text { و الفكر :"تردد القلب في الشيء..." (rال.) }
\end{aligned}
$$

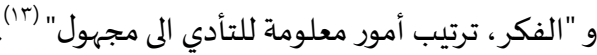

$$
\begin{aligned}
& \text { و "الفكر ، بالكسر وبفتح: إعمال النظر في الشيء..." (1). } \\
& \text { (1) معجم الرائد، حرف (الميم) مادة (أ س س)، (ص 0.0). }
\end{aligned}
$$

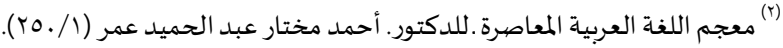

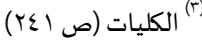

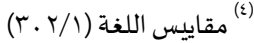

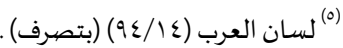

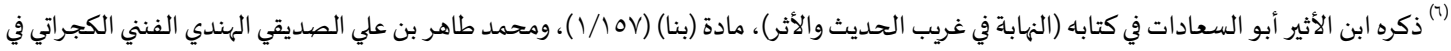

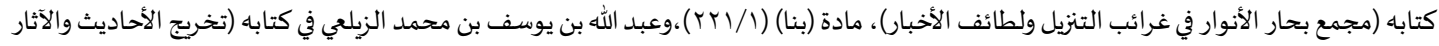

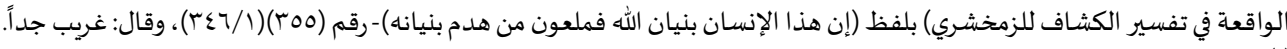

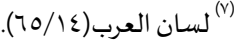

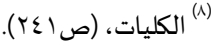

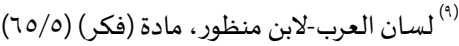

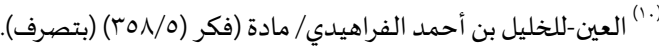

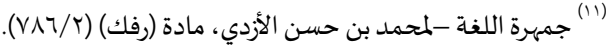

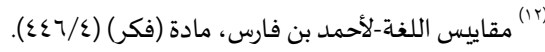

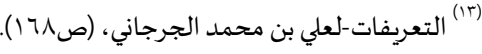




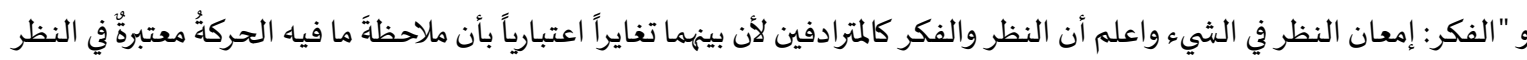

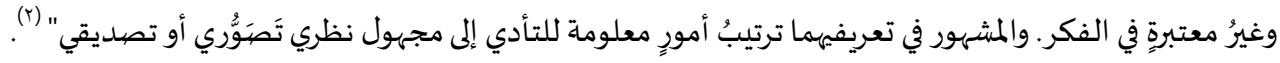

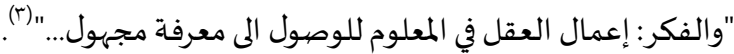

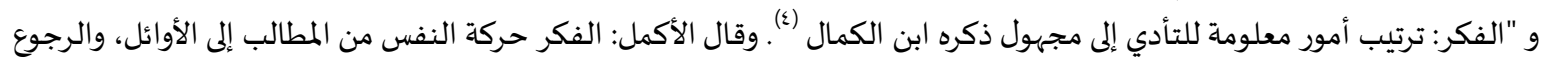

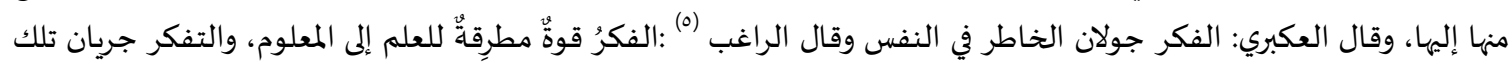

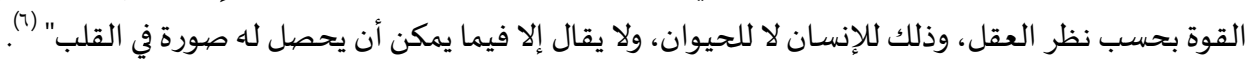

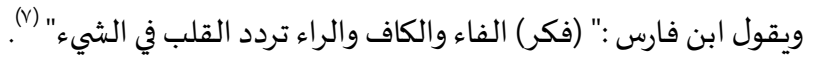

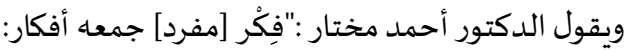

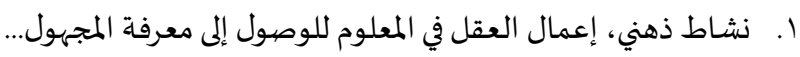

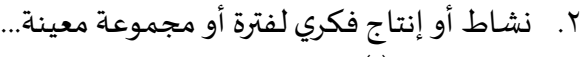

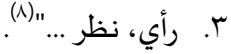

معنى الفكر في الاصطلاح: وكما تعددت مفاهيم (الفكر) وتعريفاته في اللغة تعددت كذلك في الاصطلاح إلا أن كلا المفهومين: اللغوي

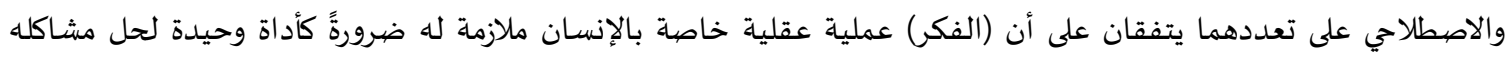

المختلفة.

• فعرفه طه جابر علوان بقوله :"الفكر اسم لعملية تردد القوى العاقلة المفكرة في الإنسان، سواء أكان قلباً أو روحاً أو ذهناً

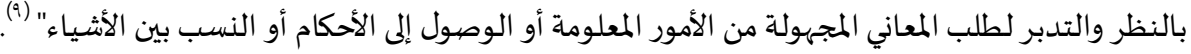

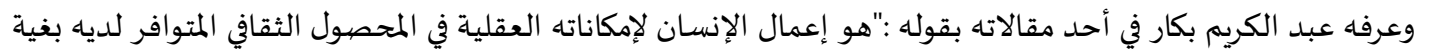

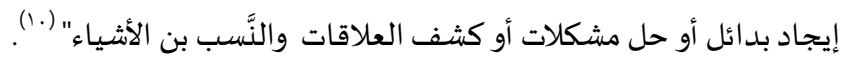

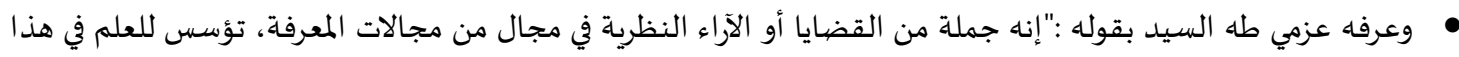

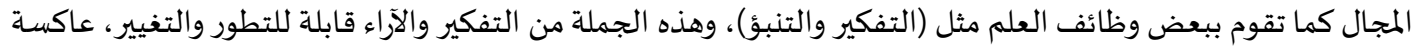

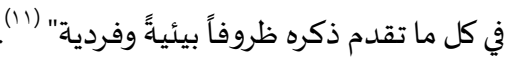

الفروق اللغوية بين المصطلحات المقاربة.

وعند النظر في تعريفات الفكر اللغوية والاصطلاحية يلاحظ أنها قد وردت بصيخ متعددة مثل:

• • • • •

فهل هذه الألفاظ الثلاثة: النظر، و والخاطر ، والعقل، ألفاظ مرادفة للفكر وأنها بمعنى واحد؟ أم أن هناك فرقاً ؟

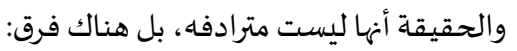

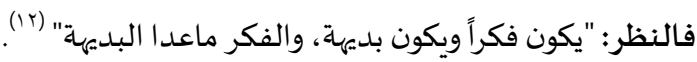

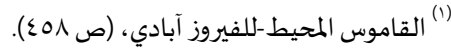

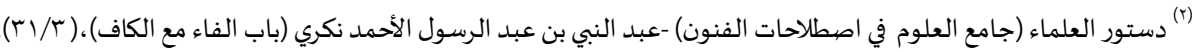

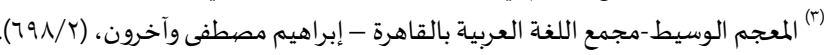

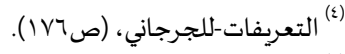

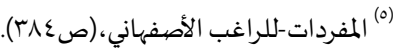

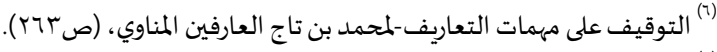

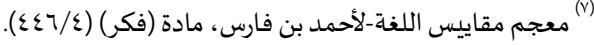

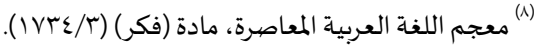

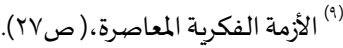

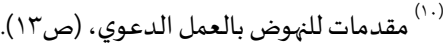

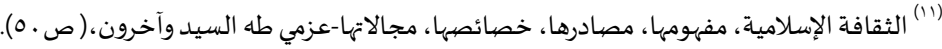

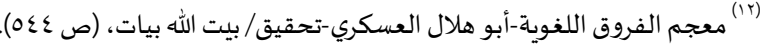




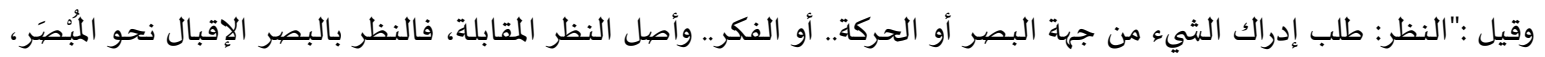

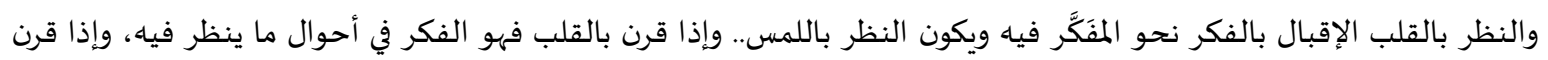

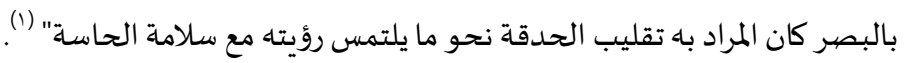

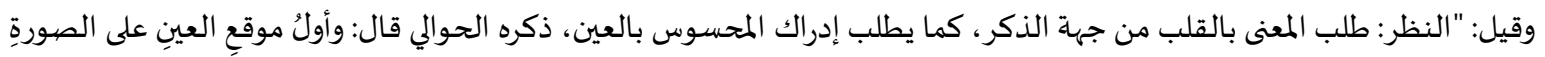

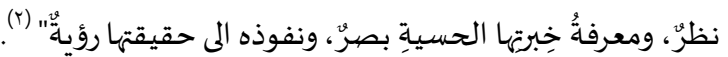

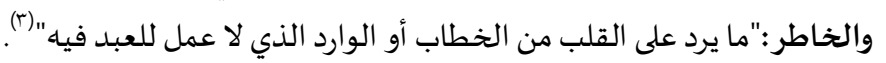

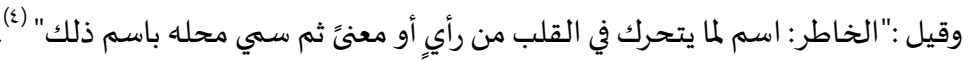

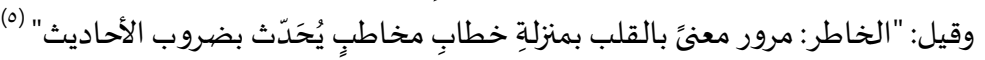
والعقل :"هو العلم الأول الذي يزجر عن القبائح... وقال بعضهم: العقل الحفظ يقال: عقلت دراهمي أي حفظتها... وقيل: العقل يفيد

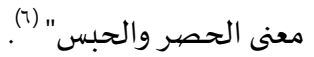
وقيل :"العقل: العلم بصفات الأشياء من حسنها وقبحها وكمالها ونقصانها.

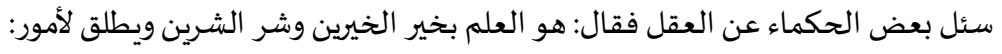

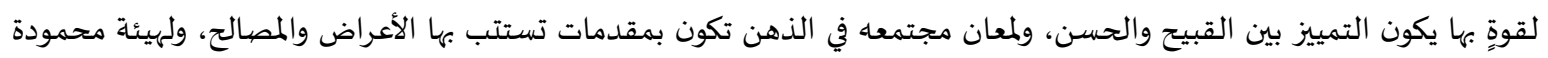
لإلنسان في حركاته وكلامها. والحق أنه نور روحاني به تدرك النفس العلوم الضرورية والنظرية وابتداء وجوده عند اجتنان الولد ثم لا يزال ينمو إلى أن يكمل عند البلوغ. والحق أنه نور في بدن الآدمي يضيء به طريقاً يُبْتَدَاً به من حيث ينتهي إليه درك الحواس، فيبدو به المطلوب للقلب، فيدرك القلب بتوفيق الله وهو كالشمس في الملكوت الظاهرة.

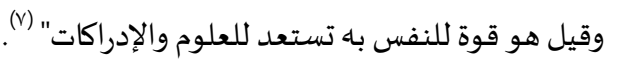

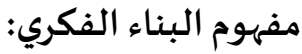

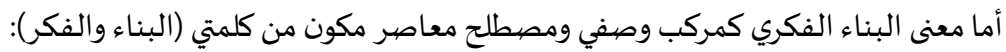

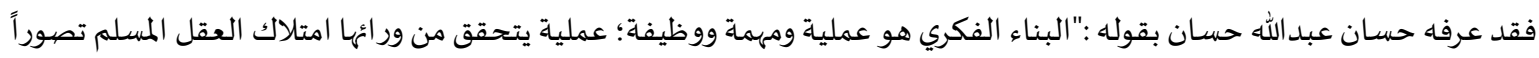

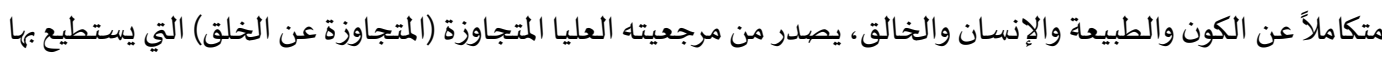

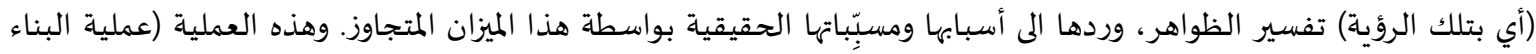

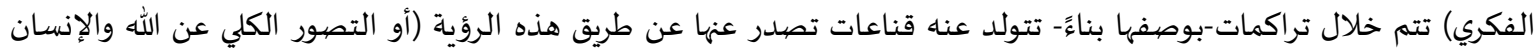

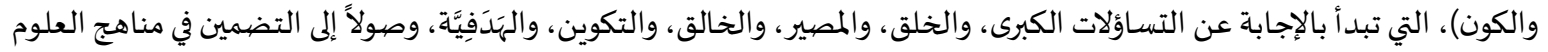

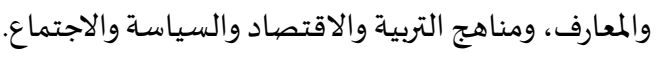

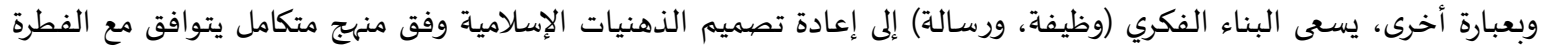

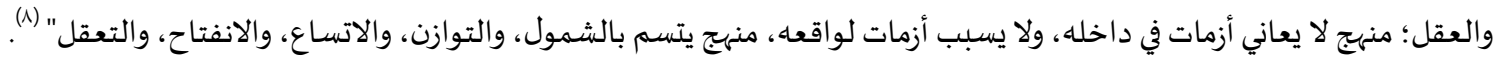

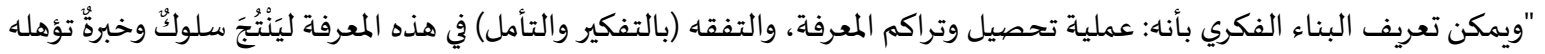

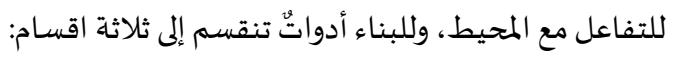
تأسيسية مثل: التربية والعبادة والفطرة.

(1) الفروق اللغوية-أبو هلال العسكري، (ص0V0،V0) (بتصرف).

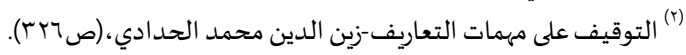

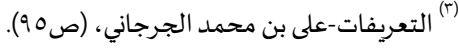

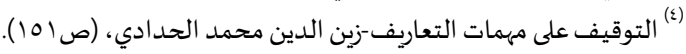

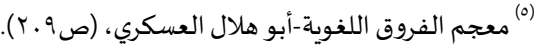

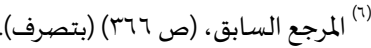

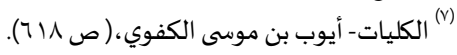

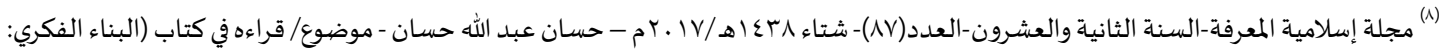

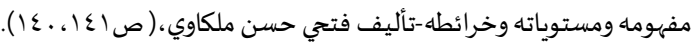

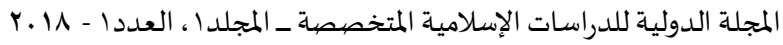


الأدوات المعرفية: كالقراءة والمناقشـة والتجارب والاستماع والمشاهدة.

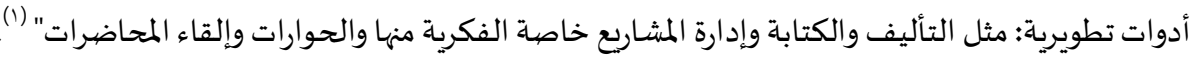

$$
\begin{aligned}
& \text { المبحث الأول: الأسسرة } \\
& \text { ويشتمل على: } \\
& \text { 1. مفهوم الأسرة. } \\
& \text { r. أهتمام القرآن بالأسرة. } \\
& \text { r. أهمية الأسرة في بناء الفكر. }
\end{aligned}
$$

معنى الأسـرة في اللغة: "الأسرة من الرجل: الرهط الأدنون وعشيرته؛ لأنه يتقوى بهم" (؟).

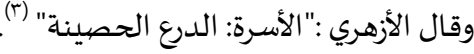

و "الأسرة : الدرع الحصينة وأهل الرجل وعشيرته والجماعة يربطها أمرّ مشترك" (ع).

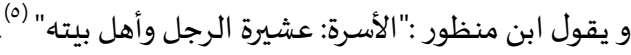
والأسرة في الاصطلاح: عدم ورود مصطلح (الأسرة) في القرآن والسنة جعل من الصعب جداً تحديد معناه في الاصطلاح رغم شيوعـه

اجتماعياً وقد عرفت بأها: "الوحدة الأولى للمجتمع وأولى مؤسسـاته التي تكون العلاقات فهيا في الغالب مباشرة ويتم داخلها تنشئة الطفل اجتماعياً

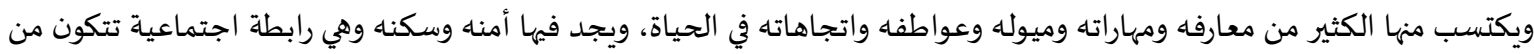

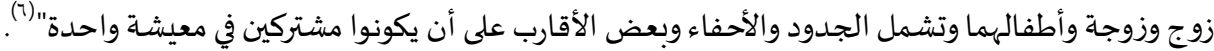

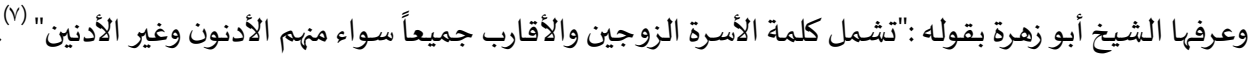

\section{اهتمام القرآن بالأسـرة:}

تعتبر الأسرة أولى المؤسسات وأهمها في بناء الإنسـان بناءً شمولياً: روحياً، وعقلياً، وفكرياً، وأخلاقياً، ونفسياً، وعاطفياً.. منذ ولادته

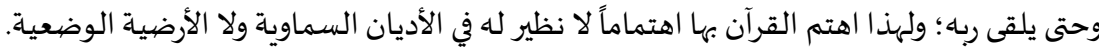

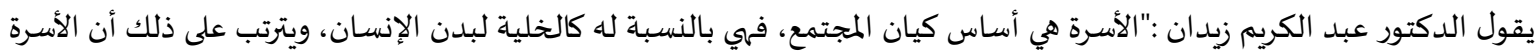
إذا صلحت صلح المجتمع وإذا فسدت فسد المجتمع، ولهذا اعتنى النظام الاجتماعي الإسلامي بالأسرة عناية كبيرة تظهر في الأحكام الكثيرة

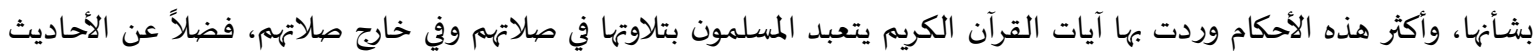

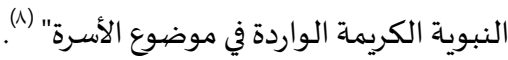
ويقول الدكتور نبيل السمالوطي :"يهتم الإسلام بشكل ملحوظ بلبناء الأسرة-أسلوب تكوينها، والنظم المؤدية إليها، كالخطبة والزواج

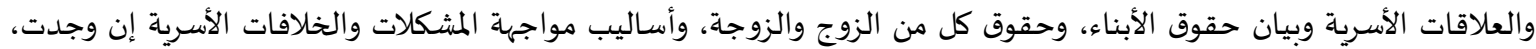

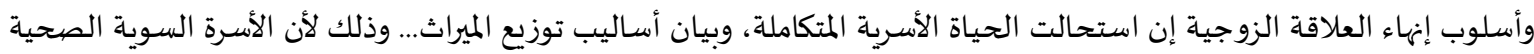
هي أساس الحياة الاجتماعية السوية، وهي أساس المجتمع المتكامل، ولا يخفى أن المجتمع ليس إلا مجموعة من الأسر المتفاعلة فإذاذا

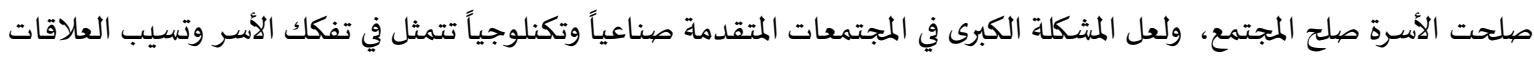

") مجلة المنار الثقافية الدولية الإلكترونية- البناء الفكري وقبول الأفكار - خالد دربندي.

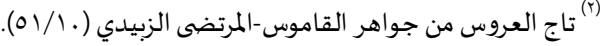

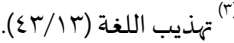

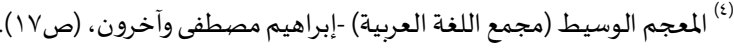

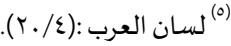

(7) دور الأسرة في إعداد القائد الصغير - د/ هاني السيد العزب، (ص/1) ).

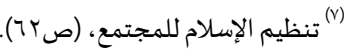

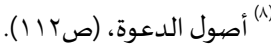

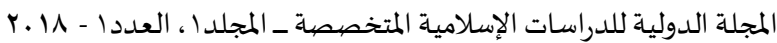


داخلها، وهذا هو ما دعا المصلحين إلى التركيز على ضرورة الحرص على بناء الأسرة على دعائم قوية، وتتضح هذه الدعائم بشكل واضح

ومعجز في التنظيم الإسلامي للأسرة" (1).

\section{مظاهر اهتمام القرآن بالأسرة:}

ويمكن إبراز اهتمام القرآن الكريم بالأسرة في المظاهر الآتية:

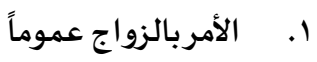

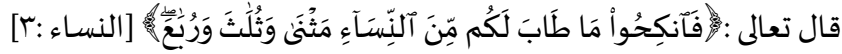

بغض النظر عن دلالة (الأمر) سواء كان للوجوب أو للندب أو للإباحة على خلاف بين العلماء...

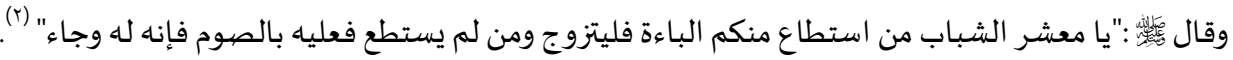

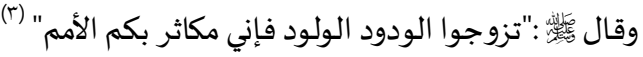

\section{الأمربتزويج الصيالحين وتزوُّج الصيالحات.

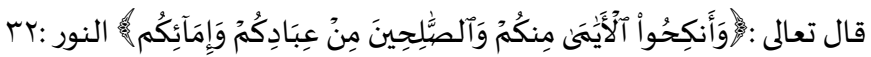

في الآية "يأمر تعالى الأولياء والأسياد بإنكاح من تحت ولايتهم من الأيامى وهم: من لا أزواج لهم من رجال، ونساء، ثِّب وأبكار"

"والصلاح: هو الإيمان. وذكر سبحانه الصلاح في المماليك دون الأحرار لأن الغالب في الأحرار الصلاح بخلاف المماليك" (0).

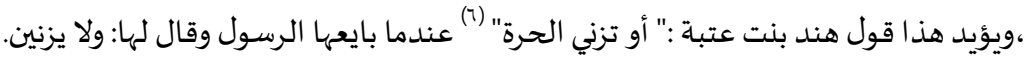

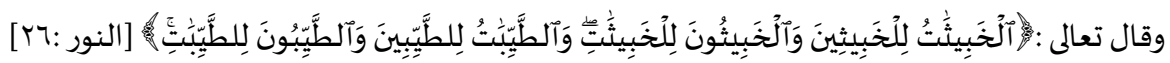

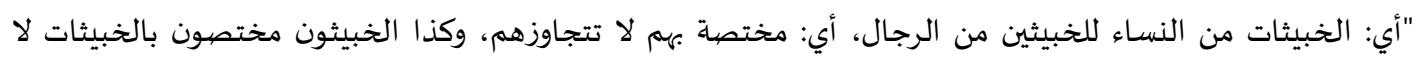

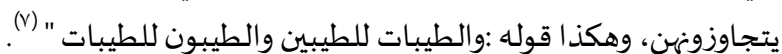

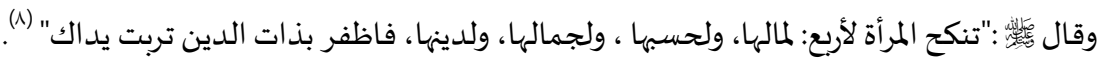

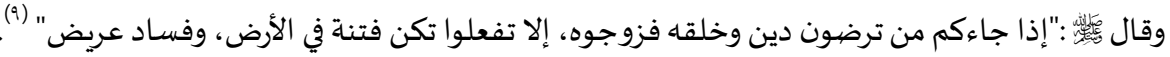

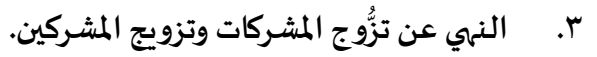

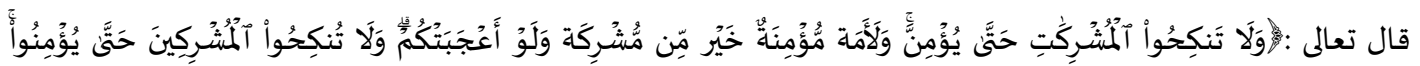

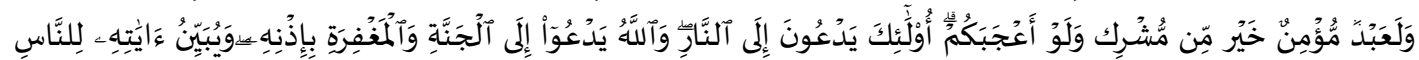

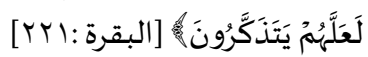



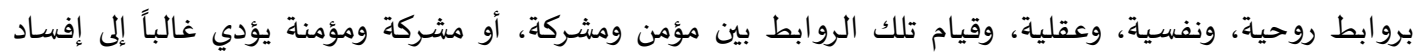

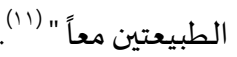

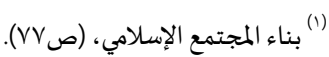

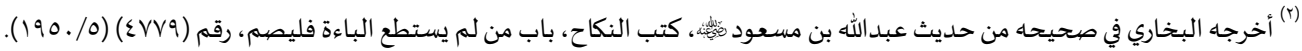

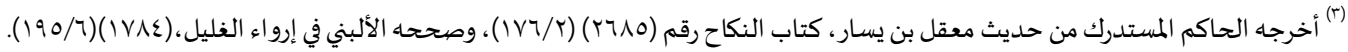

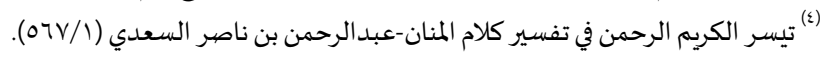

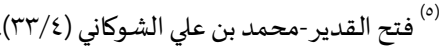

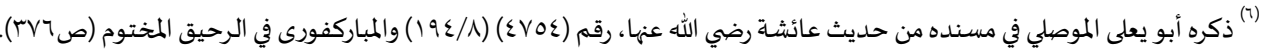

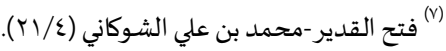

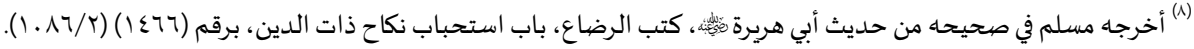

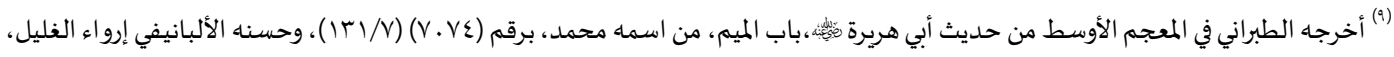

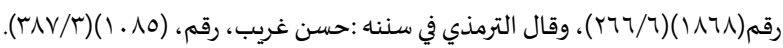

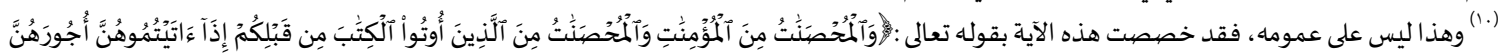

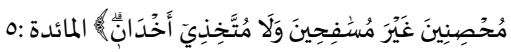

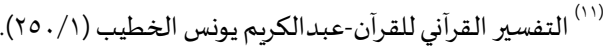

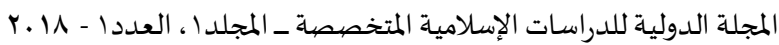


فالأبوان يمثلان "أول لبنة في بناء الأسرة وبناء المجتمع؛ لأها لو لم تكن مؤمنة، فماذا سيحدث؟ إهها ستشرف على الطفل

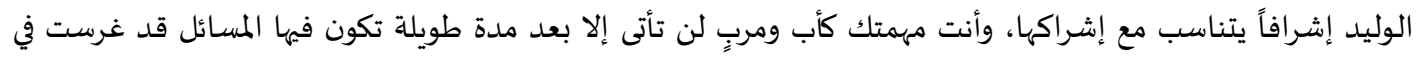

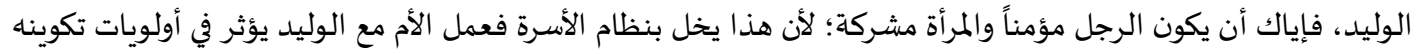

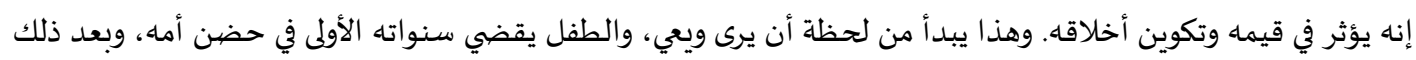

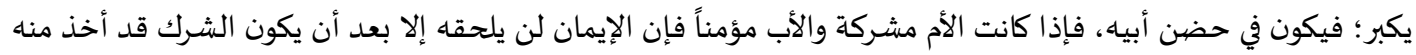

وتمكن وتسلط عليه...

إن الحق سبحانه وتعالى يريد أن يضمن لمن جعله خليفة في الأرض عقيدة واحدة يصدر عنها السلوك الإنساني؛ لأن العقائد

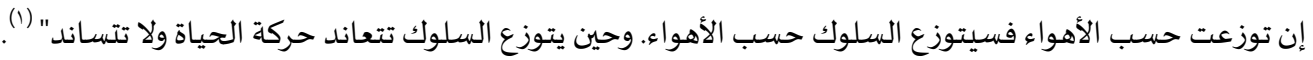

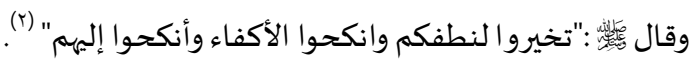

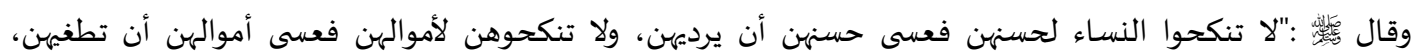

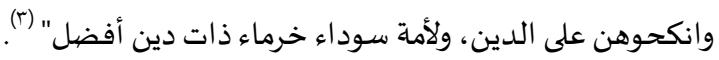
ع. الحث على الإنجاب.

واهتماماً بالأسرة حث الإسلام الزوجين على الإنجاب بعد الزواج، وأن يتضرعا إلى الله بأن يرزقهما الذربة الصالحة.

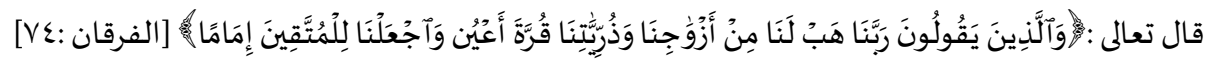

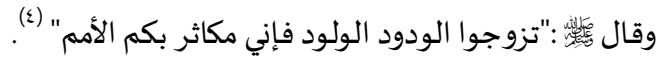

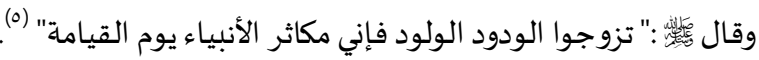

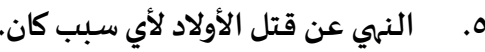

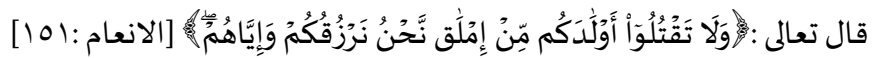

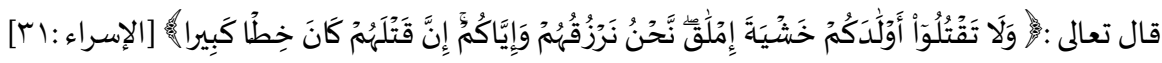

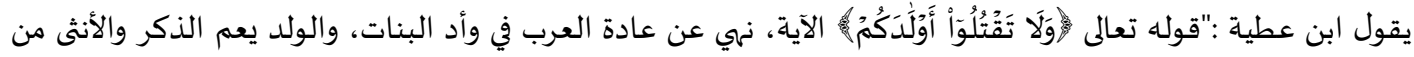
البنين"(7)

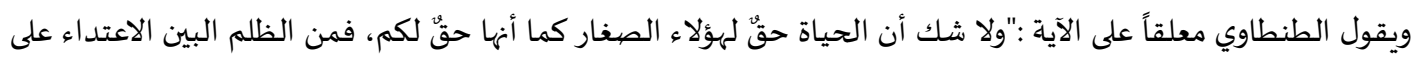

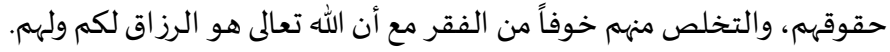
والمجتمع الذي يبيح قتل الأولاد خوفاً من الفقر وخوفاً من العار لا يمكن أن يصلح النح شأنه؛ لأنها مجتمع نفعي تسوده الأثرة والأنانية" (v)

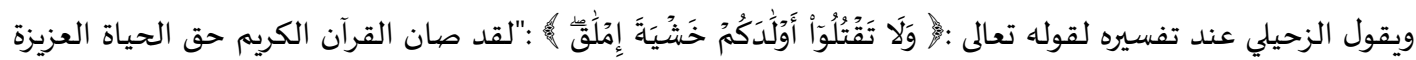

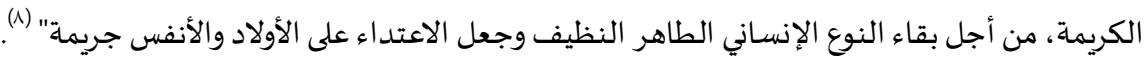

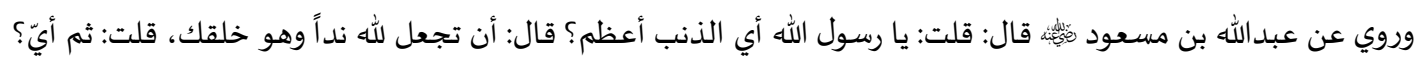

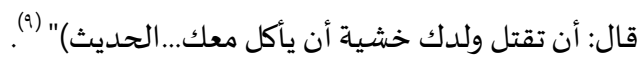

$$
\text { (1) تفسير الشعراوي-محمد متولي الشعراوي (T/T/ (1) (97) (بتصرف). }
$$

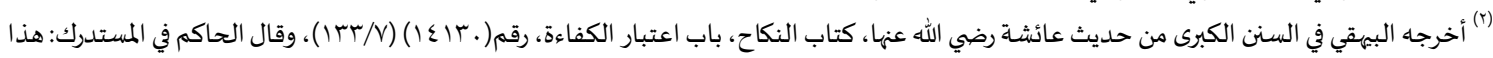

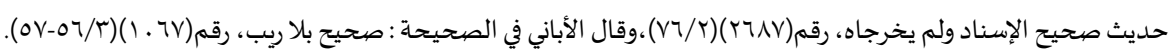

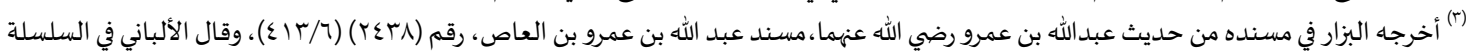

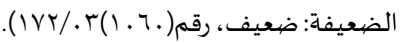

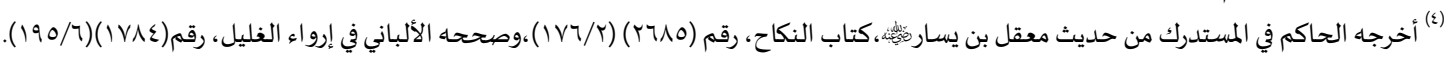

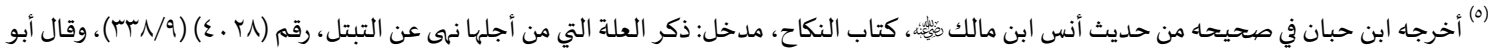

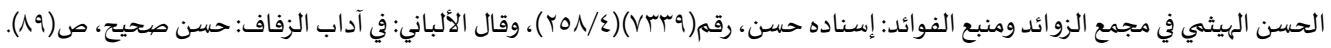

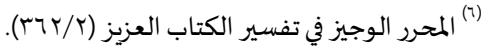

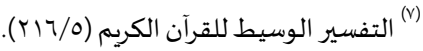

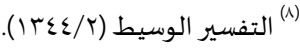

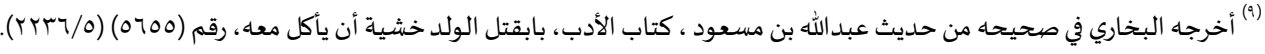


7. الأمر بالنفقة على الأسرة.

فقد وردت آيات كثيرة في وجوب الإنفاق على الأسرة وفي مقدمتها: الزوجاة والأولاد وفي حالات مختلفة، وليس هذا محل عرضها

واستيفائها وسنكتفي بعرضها على سبيل الإجمال، منها:

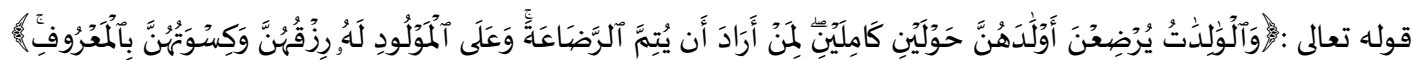

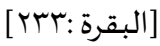

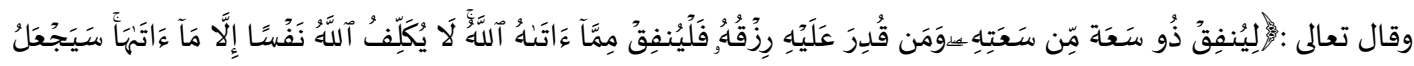

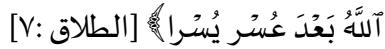
[7قال فهذه الآيات صريحة وواضحة في تكليف الرجل بالنفقة على الأسرة، وهناك الكثير من الأحاديث التي تدل على حق الأسرة في النفقة، وتكليف الرجل بها، منها:

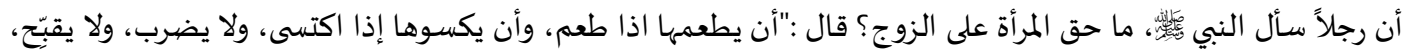

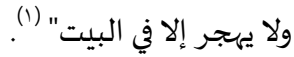

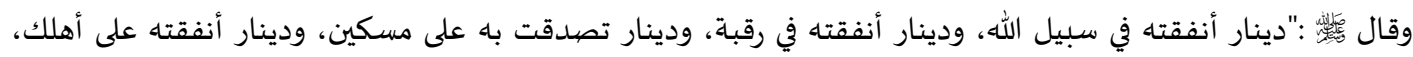
أعظمها أجراً الذي أنفقته على أهلك" (؟).

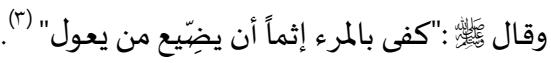

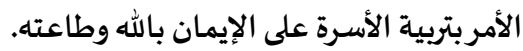

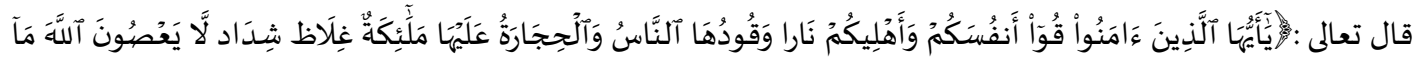

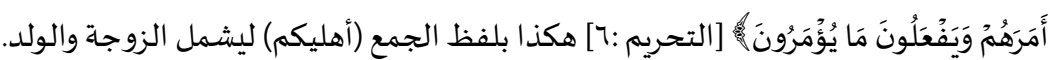

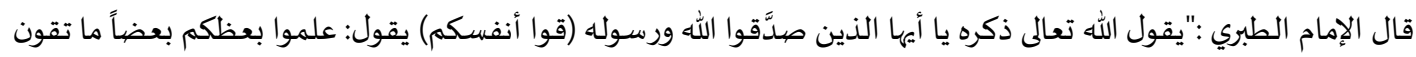

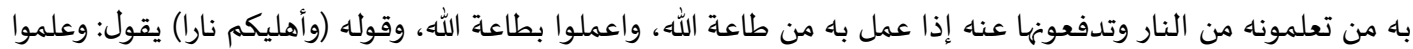

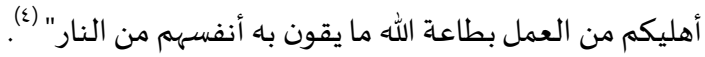

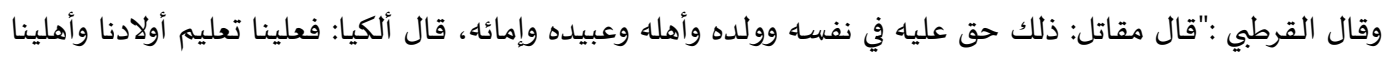

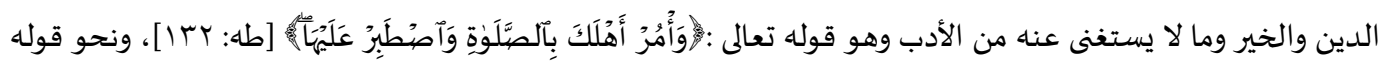

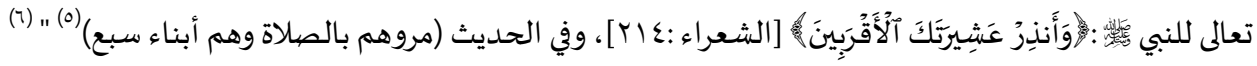
وقال والمرأة في بيت زوجها راعية وهي مسؤولة عن رعيتها، والخادم في مال سيده راع وهو مسؤول عن رعيته" (vواعو . ^. تشريع جملة من الأحكام التفصيلية الخاصة بالأسرة. من شأنها أن تنظم الاسرة وتحافظ عليها حتى تتمكن من أداء دورها في البناء الشمولي للفرد والمجتمع: روحياً، وعقلياً، وفكرياً.

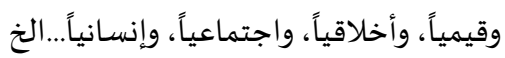

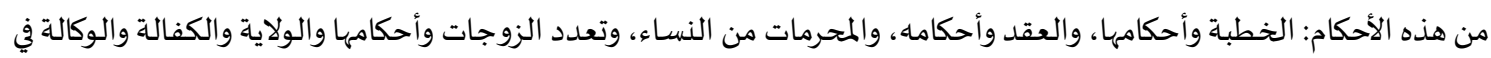

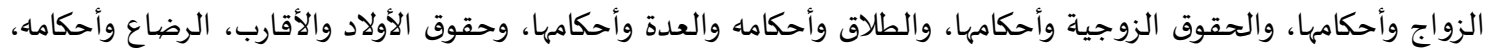

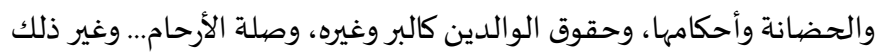

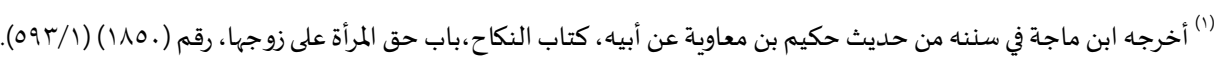

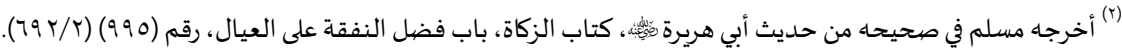

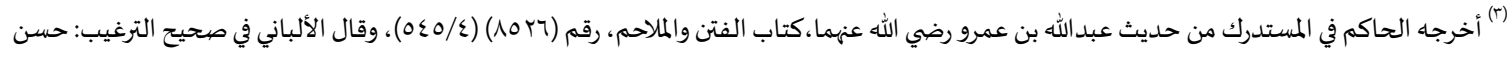

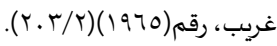

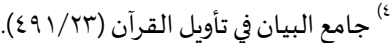

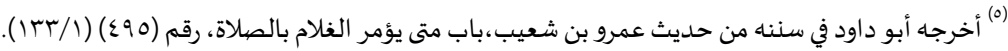

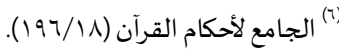

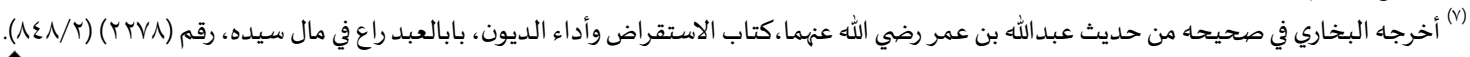


أهمية الأسسرة في بناء الفكر:

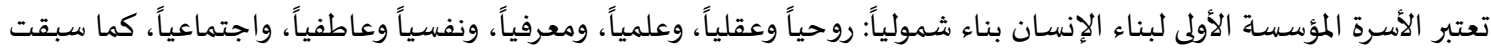

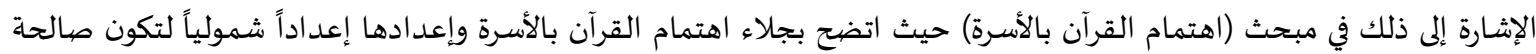

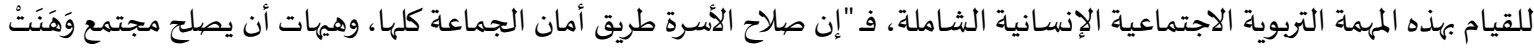

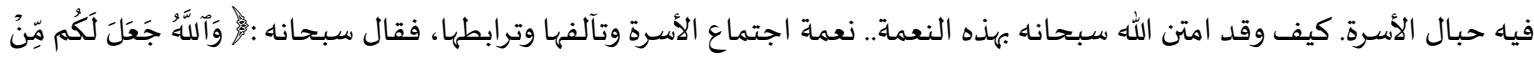

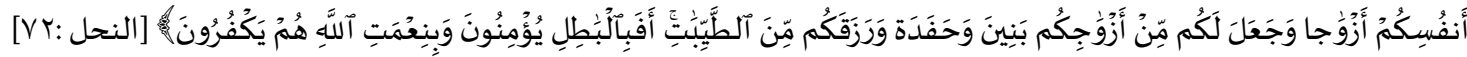

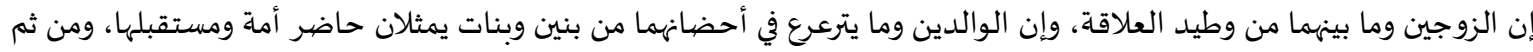

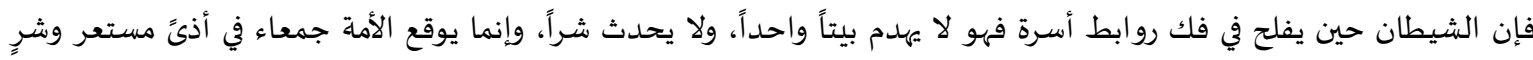

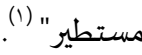
والأسرة "كانت ولا تزال المؤسسة الوحيدة التي تعلم وتهذب الطفل وتنقل إليه عن طريق الأب خبرات الحياة ومهارتها المحدودة، ، ومعارفها

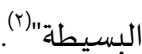

مظاهر أهمية الأسرة في بناء الفكر. ويمكن إبراز أهمية الأسرة في بناء الفكر في المظاهر الآتية:

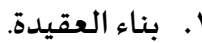

ففي الأسرة يتم بناء الأبناء عقدياً ومنذ اللحظة الأولى لخروجهم إلى الحياة،

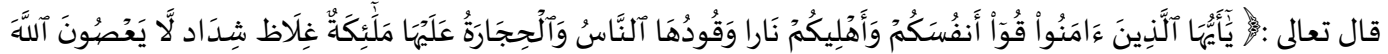

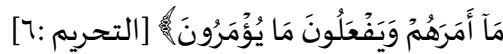

ولا يمكن أن تتحقق هذه الوقاية إلا بعقيدة صحيحة قائمة على توحيد الله في ألوهيته وربوبيتها وأسمائه وصفاتها...

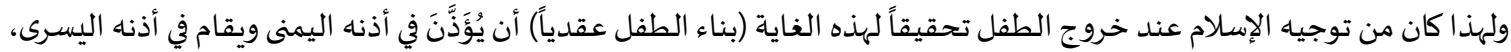

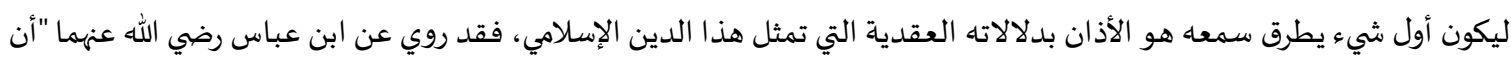

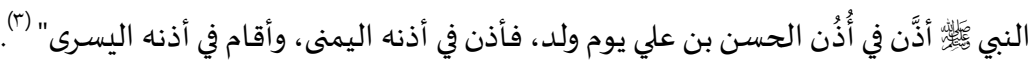

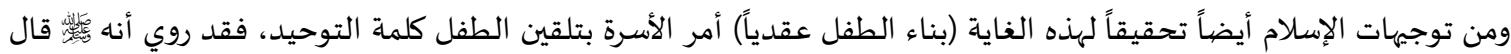

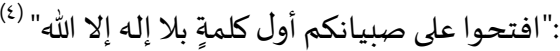

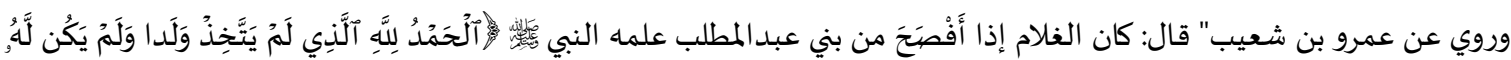

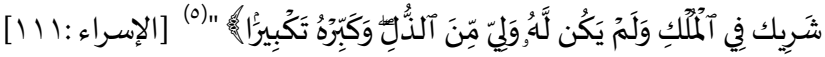
r. المحافظة على الفطرة وحمايتها من الانحراف. فهذه من المهمات الأساسية التي تضطلع بها الأسرة وتقوم بها تجاه أفرادها وهي من المهمات المهات الصعبة التهافي تقع على كاهل الأسرة خاصةً في عصرنا الحاضر.

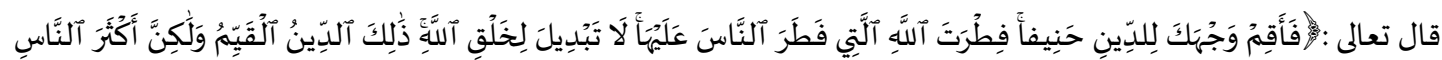

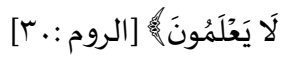

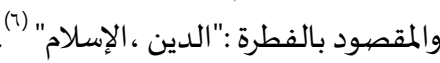

$$
\begin{aligned}
& \text { (1) البيت السعيد وخلاف الزوجين-د/ صالح بن عبدالله بن حميد، (ص } 7 \text { (1) ). }
\end{aligned}
$$

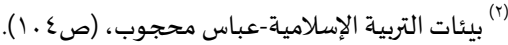

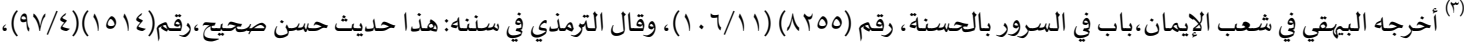

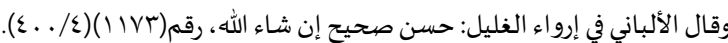

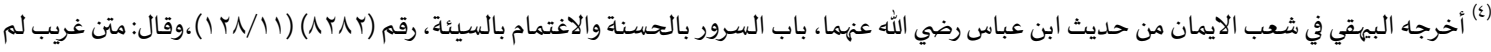
نكتبه إلا بهذا الإسناد.

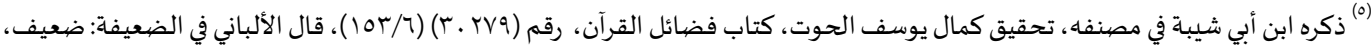

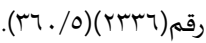
(1) تفسير مجاهد-مجاهد بن جباهبر). 
قال الطبري:"حدثني يونس، قال: أخبرنا ابن وهب، قال: قال ابن زيد في قوله: (فطرة الله التي فطر الناس عليها) قال: الإسلام مذ خلقهم

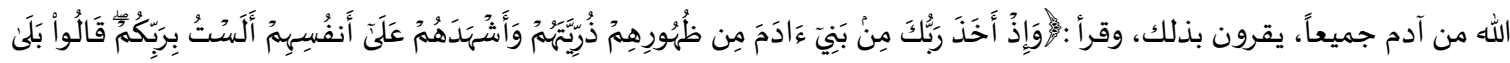

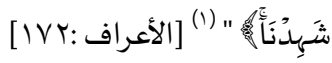
وإن مهمة الأسرة تجاه هذه الفطرة التي فطر الله علهها المواليد مهمة مزدوجة: مهمة محافظةٍٍ. من أي تغيير أو تبديل، أو زيادة أو نقصيان.

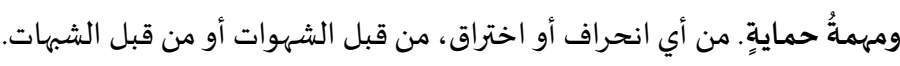

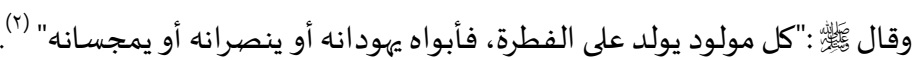

فالحديث ينص على أن هذه الفطرة قد تتعرض للتشويه والانحراف بفعل التوجيه والتربية الخاطئة التي تقوم بها الأسرة وعلى رأسها وفي مقدمتها الأبوان. r. التعبيد والتعويد.

أي التعبيد الله والتعويد على طاعته. وهذه إحدى مهمات وأهمية الأسرة في بناء الفرد بناء شمولياً، وهي تعبيده لله وتعويده على

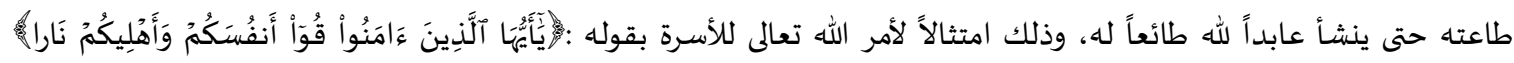

[7: التحريم

وإن هذه الوقاية لا يمكن أن تتحقق إلا بتحقيق العبودية لله بعد توحيده سبحانه وتعالى.

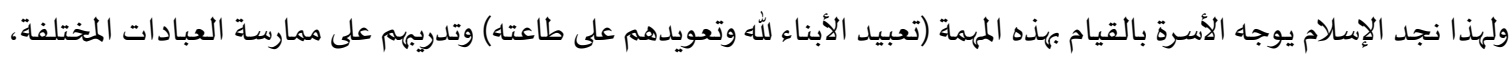

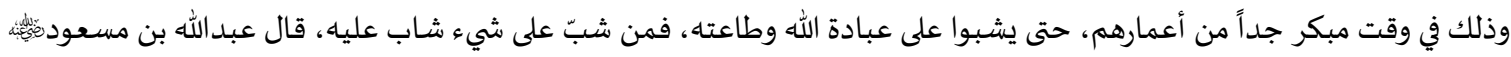

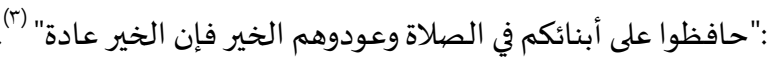
وقال الشاعر (ع) افظواعل

$$
\text { وما وينشأ ناشئ الفتيان منان }
$$

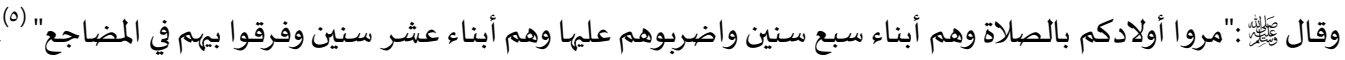

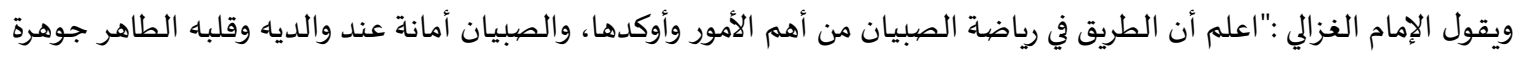

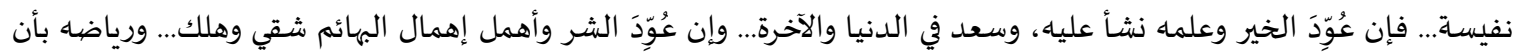

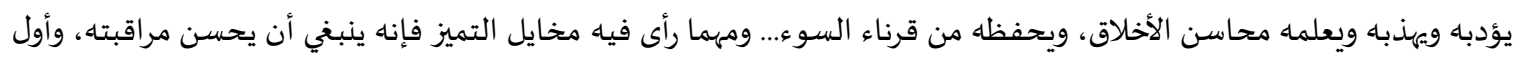

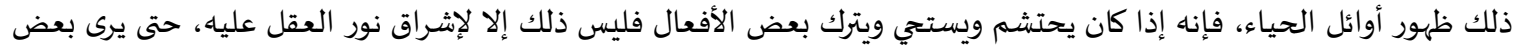

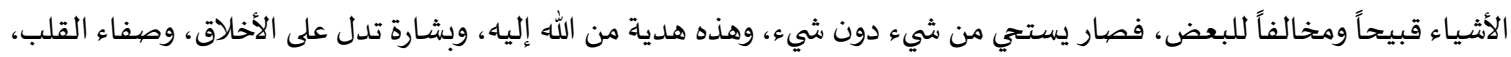

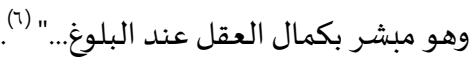
ع. التفقيه والتثقيف.

ومن مهام الأسرة التي تدخل في بناء الفرد فكرياً وبصورة مباشرةً هي التفقيه والتثقيف، وخاصة في فقه العبادة، وثقافة الحلال

$$
\text { والحرام. }
$$

فإن الأسرة هي المدرسة الفقهية، والمؤسسـة الثقافية الأولى التي يتعلم فيها الأبناء كيفية عبادة الله ويتلقون فيها ثقافة الحلال والحرام،

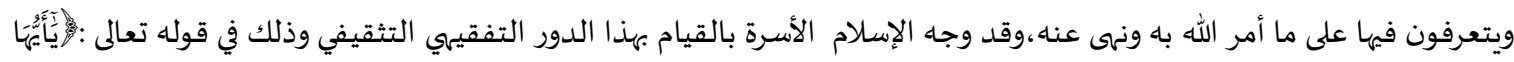

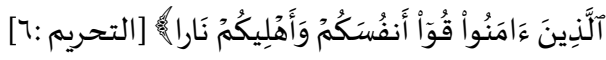

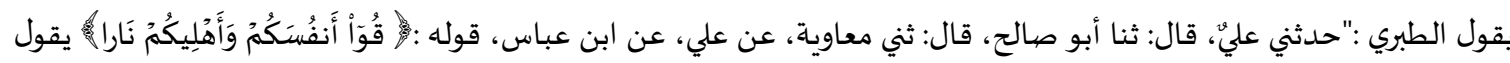

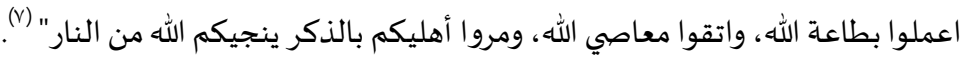

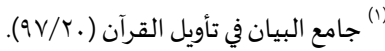

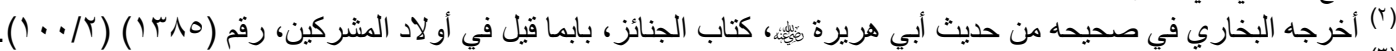

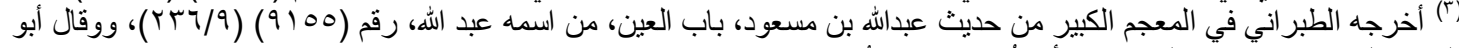

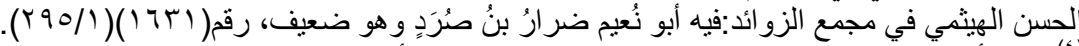

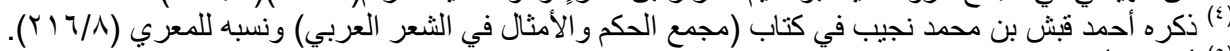

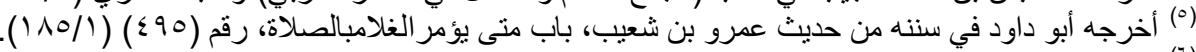

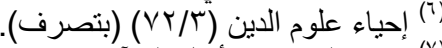

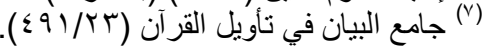


وكذلك التثقيف في أمور الحياة فإن الطفل يتلقاها داخل الأسرة وتنتقل إليه عن طريق التقليد لأبيه وأمه وأفراد أسرته في أعمالهم الهاهم

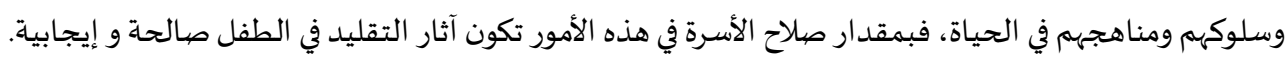

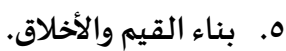

في الأسرة أيضاً يتم بناء القيم وغرس الأخلاق في نفوس الناشئة وتربيتهم على الفضيلة والتفاعل والتكافل الأسري والاجتماعي والإسلامي والإنساني. هذه هي الأسرة في الإسلام وفي القرآن، وهذه هي أهميتها: مصنع الرجال والأبطال، والمؤمنين والصالحين، والقادة والمسؤولين، والعلماء والمفكرين في شتى مجالات الحياة.

$$
\begin{aligned}
& \text { المبحث الثاني: المستجد }
\end{aligned}
$$

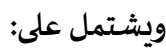

$$
\begin{aligned}
& \text { ا. } \\
& \text { r. آ اهتمام القرآن بالمسجد. } \\
& \text { r. أهمية المسجد في بناء الفكر. }
\end{aligned}
$$

$$
\text { مفهوم المستجد: }
$$

معنى المسجد في اللغة: المسجد في اللغة :"الإرب الذي يسجد عليه مثل الكفين والركبتين والقدمين والجبهة وكل إرب من هذه مسجد.

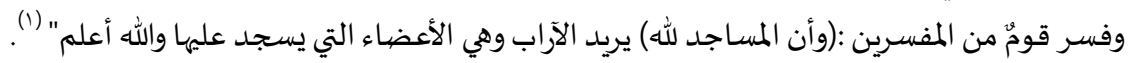

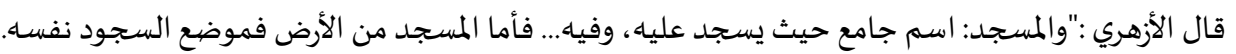

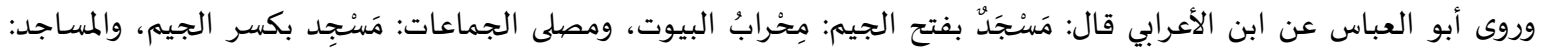

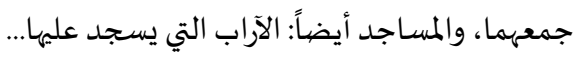

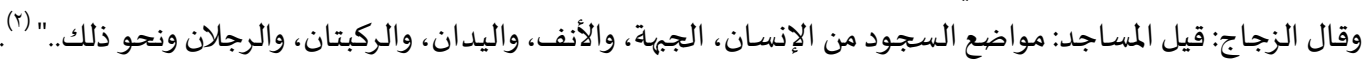

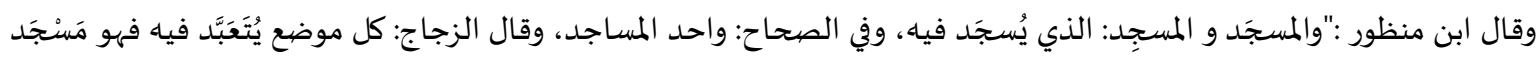

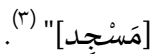

معنى المسجد في الاصطلاح: المسجد في الاصطلاح الشرعي :"موضع السجود، وهو أخفض محطِّ القائِم" (s).

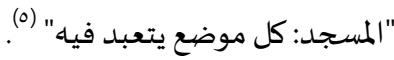

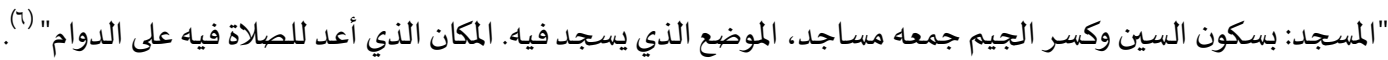

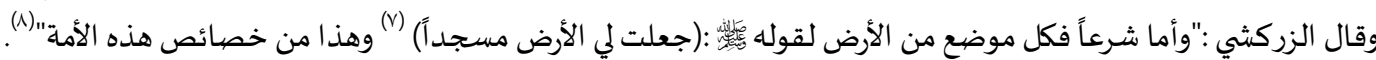

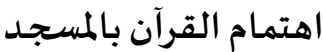

لقد اهتم القرآن بالمسجد اهتماماً عكس أهميته في الإسلام وفي حياة المسلمين، وأبان مكانته، وأوضح وظيفتها.

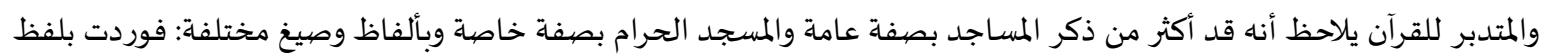

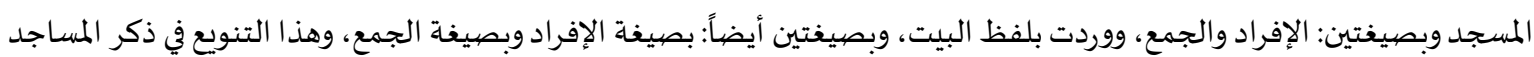
لفظاً وصيغة يعكس اهتمام القرآن بالمسجد وأهميته في حياة المسلمين.

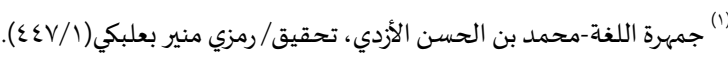

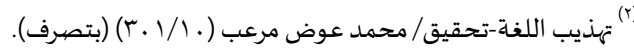

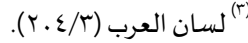

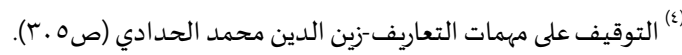

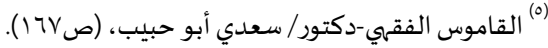

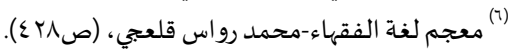

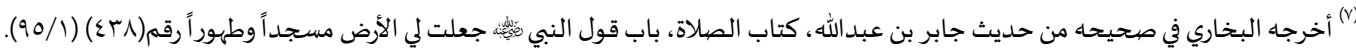

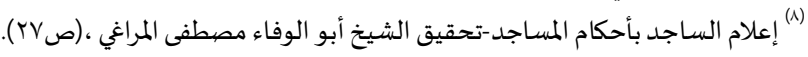


مظاهر اهتمام القرآن بالمستجد:

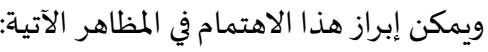

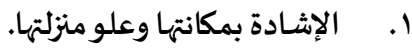

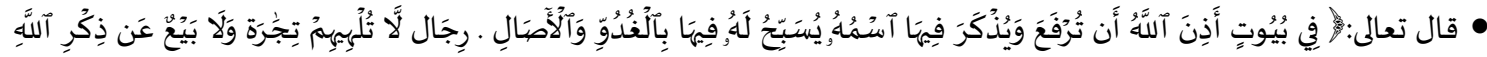

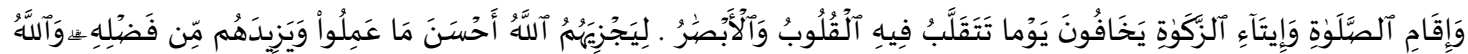

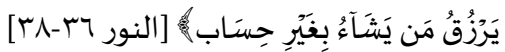

قال السعدي :"أي :يتعبد الله (في بيوت) عظيمة فاضلة، هي أحب البقاع إليه، وهي المساجد. (أذن الله) أي: أمر ووصى (أن ترفع ويذكر

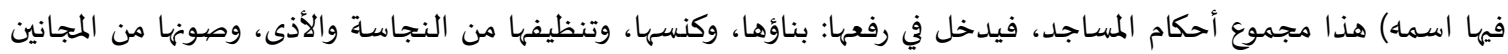

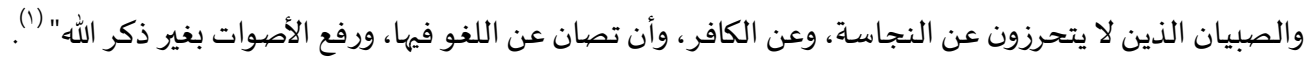

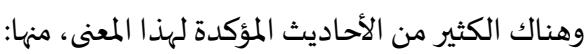

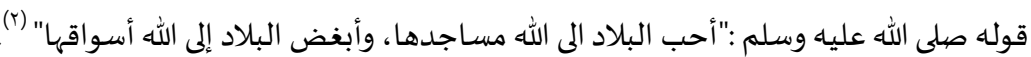

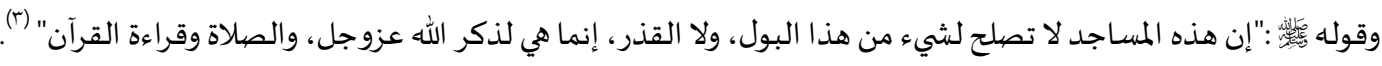
r. تشريف المساجد بإضيافتها إلى الله.

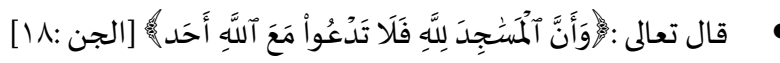

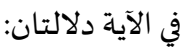

الأولى: تشريف الله للمساجد بنسبتها وإضافها إليه.

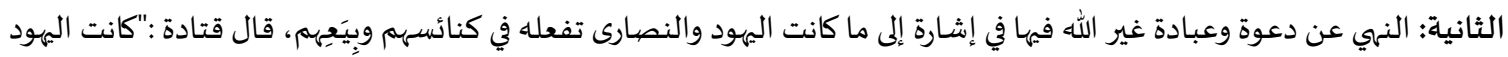

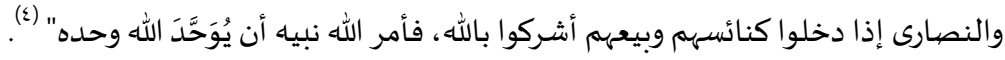

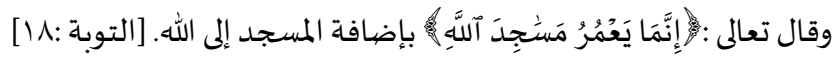

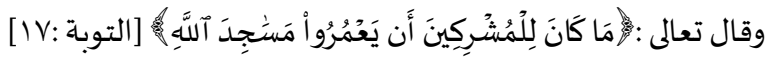

وقد وردت أحاديث كثيرة تؤكد هذا المعنى، منها:

قوله

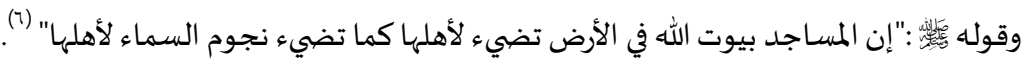

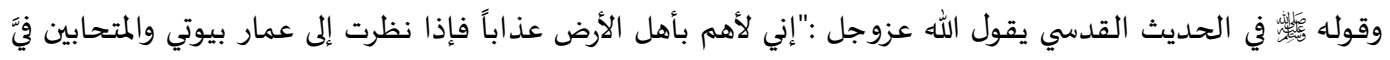

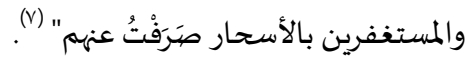

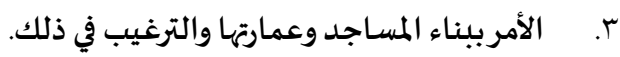

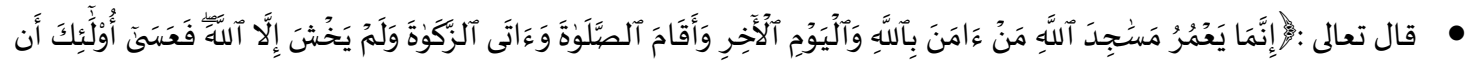

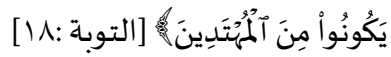

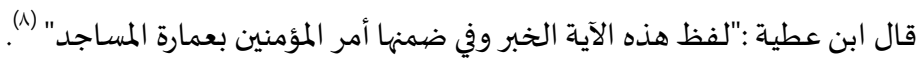

ويؤكد هذا المعنى الكثير من الأحاديث النبوية منها:

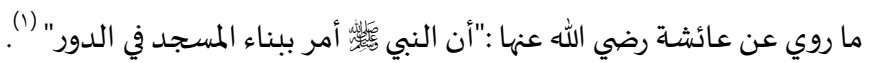

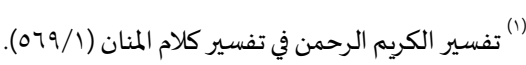

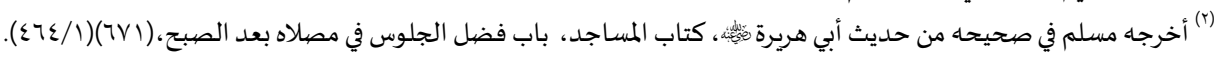

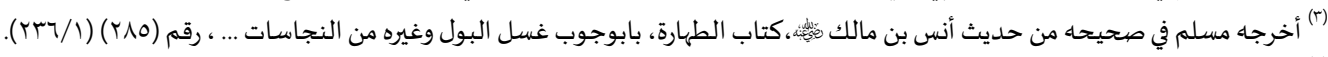

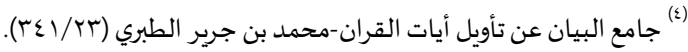

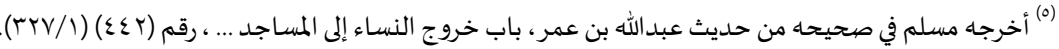

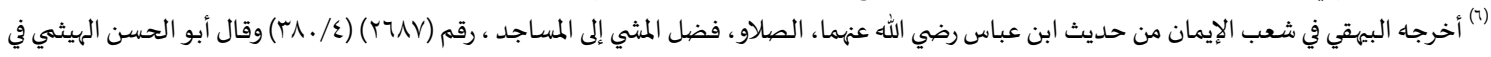

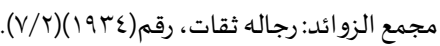

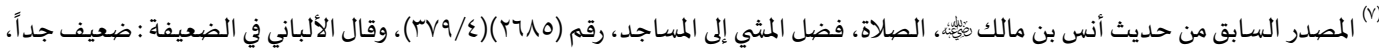

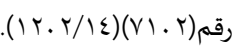

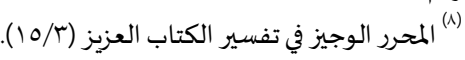

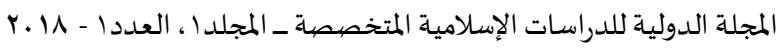




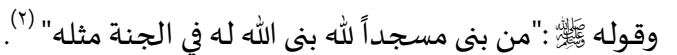

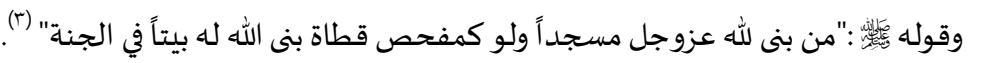

$$
\begin{aligned}
& \text { ع. تعظيم حرمة المساجد وتغليظ عقوبة المعتدين عليها. }
\end{aligned}
$$

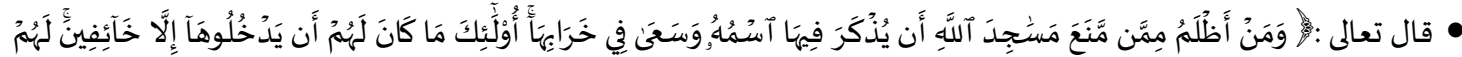

[الِي

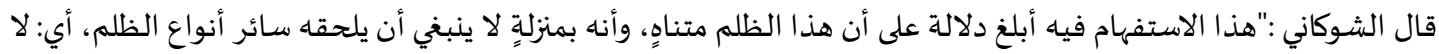

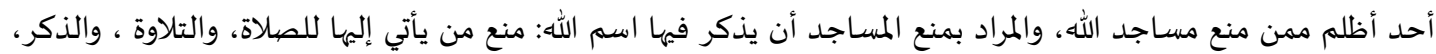

$$
\text { وتعليمها. }
$$

والمراد بالسعي في خرابها: هو السعي في هدهها، ورفع بنياها، ويجوز أن يراد بالخراب: تعطيلها عن الطاعات التي وضعت لها، فيكون

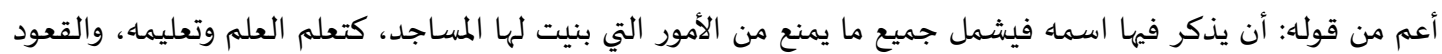
للاعتكاف، وانتظار الصلاة...

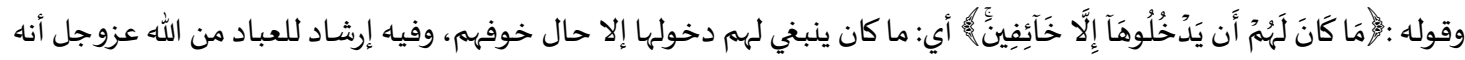

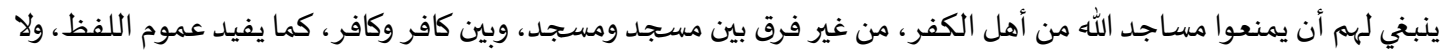

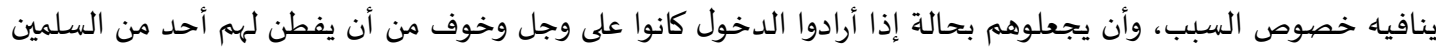

$$
\text { هذا فيُنلون بهم ما يوجب الإهانة والإذلال"(ع). }
$$

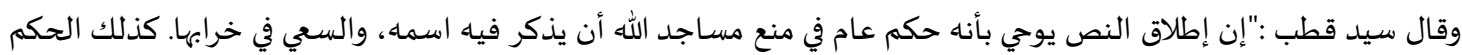

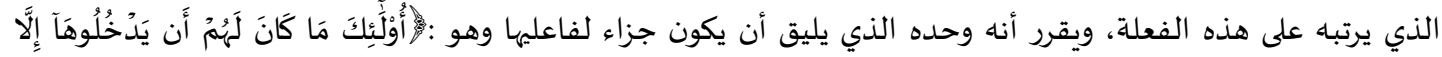

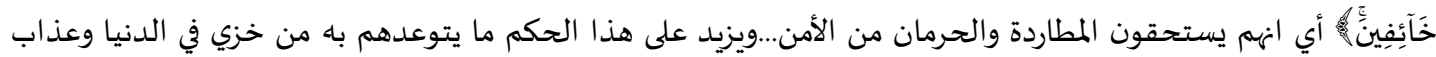
عظيم في الأخرة" (o). أي أن الله عاقب المعتدين على المساجد بثانلاث عقوبات:

الأولى: زراعة الخوف في قلوبهم عند دخولها. الثانية: الخزي والإذلال في الدنيا. الثالثة: العذاب العظيم في الآخرة.

وفي هذا إشـارة إلى عظمة حرمة المساجد، و فظاعـة الاعتداء عليها؛ فإنها بيوت الله، ودور عبادته، ومقصهد عُبَّاده.

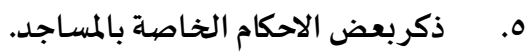

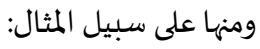

جعْل قبلة المساجد إلى الكعبة.

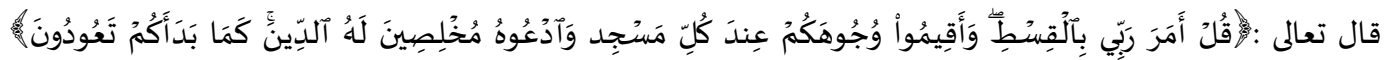

$$
\text { [rq: الأعراف] }
$$

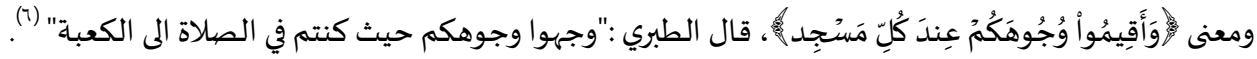

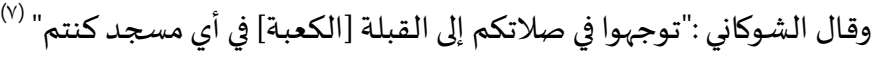

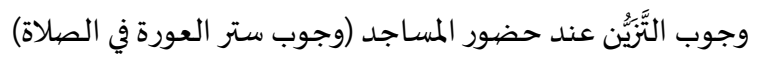

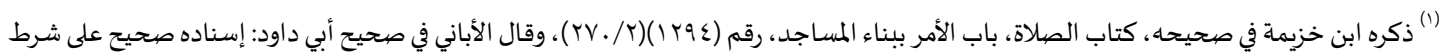

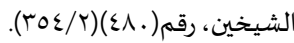

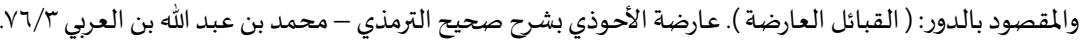

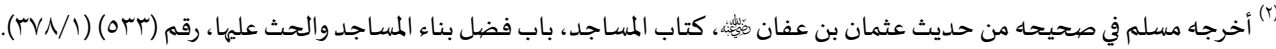

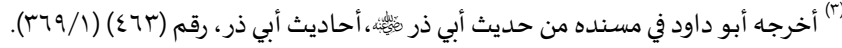

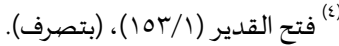

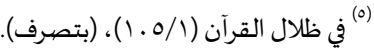

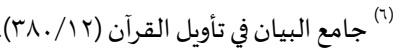

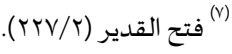




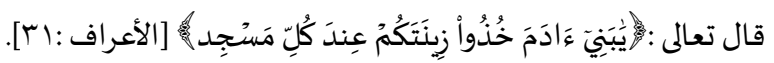

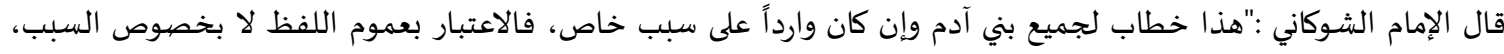

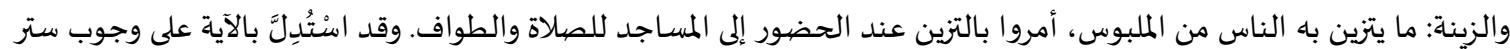

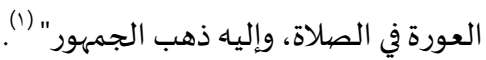

• • • الاعتكاف في المساجد، والنهي عن مباشرة النساء في حالة الاعتكاف فيها.

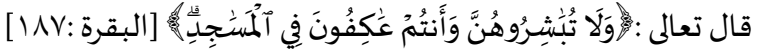

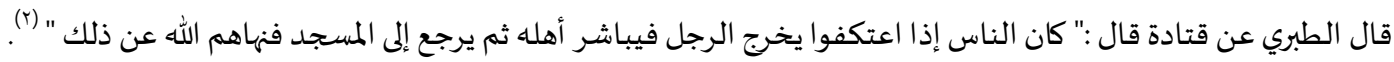

أهمية المسجد في بناء الفكر:

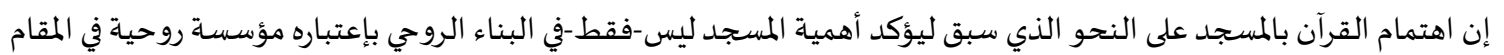

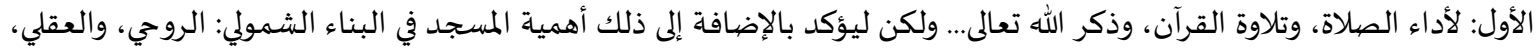

$$
\text { والعلمي، والفكري...الخ الخ الخهاء وتلاوة }
$$

فهذه هي في الحقيقة وظيفة المسجد، وهذا هو الدور الذي يقوم باه في حياة المسلمين على مستوى الفرد والجماعة لهذا؛

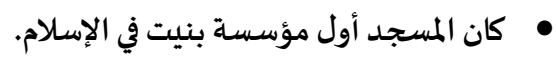

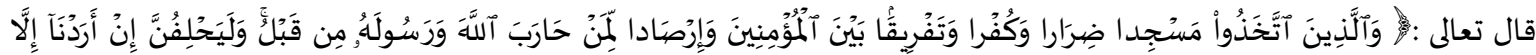

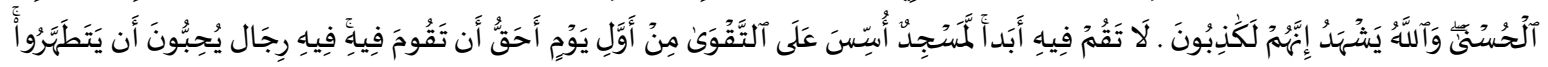

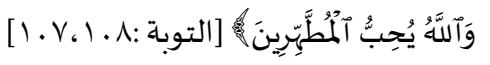

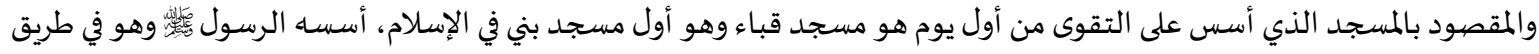

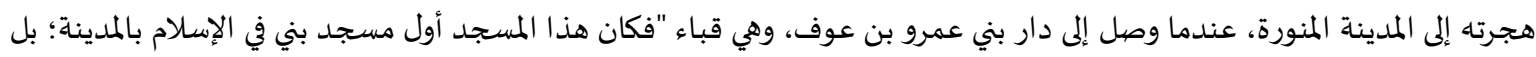

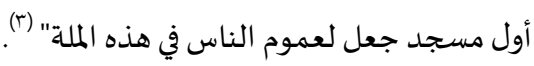

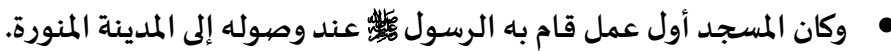

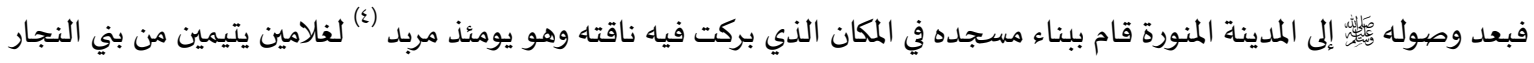

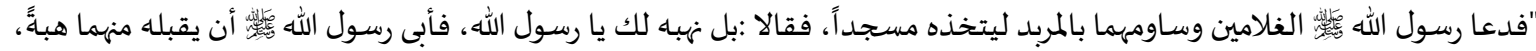

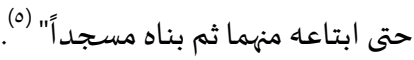

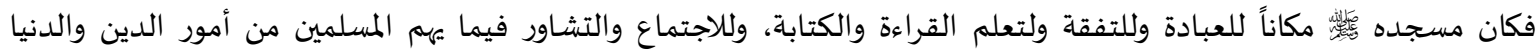

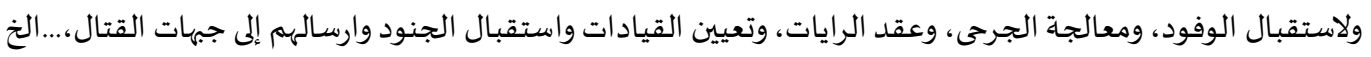

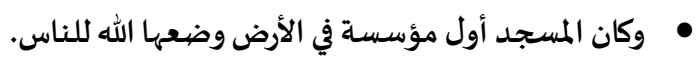

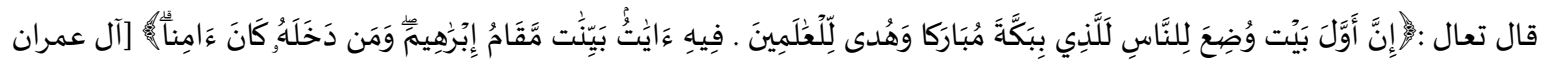

$[9 \vee .97:$

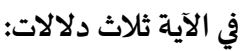

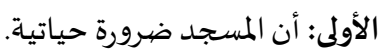

الثانية: أن المسجد حاجة إنسانية.

الثالثة: أن هاتين الدلالتين: دلالة الضرورة، ودلالة الحاجية الثانية تدلان على أهمية المساجد في حياة الناس.

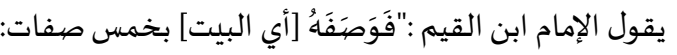

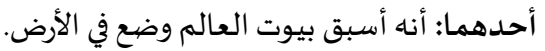

الثاني: أنه مبارك، والبركة كثرة الخير وداومه، وليس في في بيوت الرضان العالم أبرك منه ولا أكثر خيراً ولا أدوم ولا أنفع للخلائق.

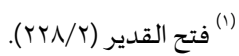

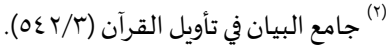

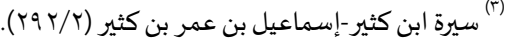

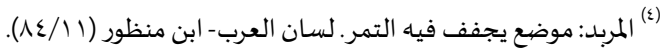

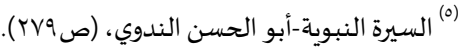

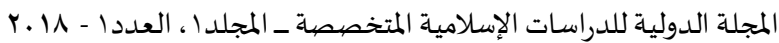


الثالث: أنها هدى، وصيفه بالمصصدر نفسـه مبالغةًة حتى كأنه هو نفس الهدى. الرابع: ما تضمناه من الآيات التي تزيد على أربعين آية. الخامس: الأمن لداخله" (1) الخعنه من الايات

مظاهر أهمية المستجد في بناء الفكر:

ويمكن إبراز أهمية المسجد في بناء الفكر من خلال المظاهر الآتية:

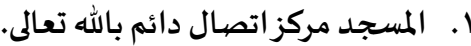

ففي المسجد يتصل المسلم بربه عبر قنوات متعددة منها:

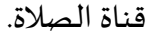

وهي من أهم قنوات الاتصال بالله، من أجلها بنيت المساجد، وعن طريقها يتصل العبد بربه خمس مرات في اليوم والليلة على سبيل

الوجوب، وإلا فالصلاة قناة مفتوحة للاتصال بالله على مدى أربع وعشرين ساعة تقريباً (r).

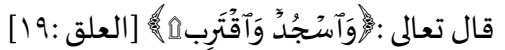

قال ابن القيم :"إن الساجد أذل ما يكون لربها وأخضع له، وذلك أشرف حالات العبد، فلهذا كان أقرب ما يكون من ربه في هذه الحالة،

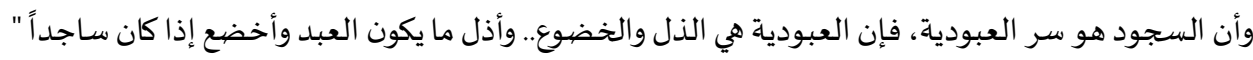

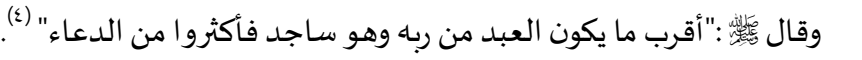

$$
\begin{aligned}
& \text { قناة تلاوة القرآن. }
\end{aligned}
$$

وهي قناة مباشرة مفتوحة على مدار الساعة للاتصال بالله عزوجل.

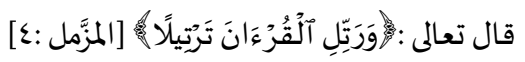

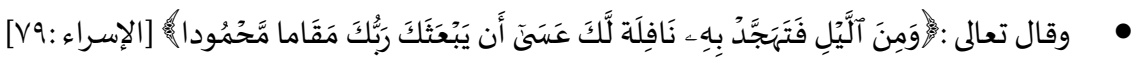

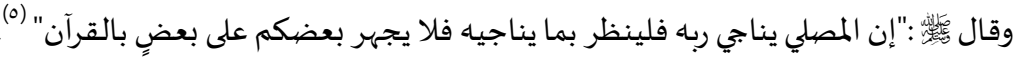

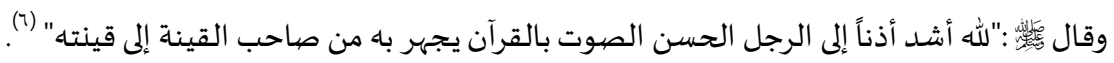

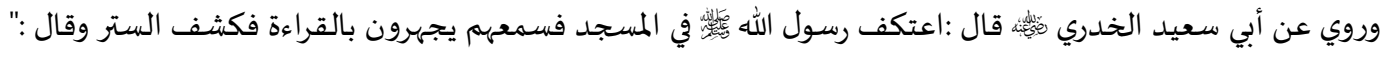

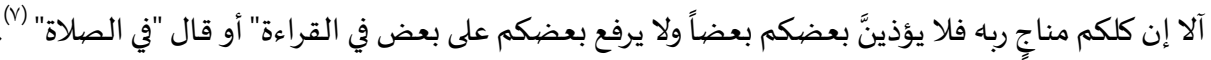

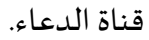

وهو من القنوات المباشرة المفتوحة للاتصال بالله تعالى في أي ساعة من ليل أو نهار. وأفضلها في الثلث الأخير من الليل.

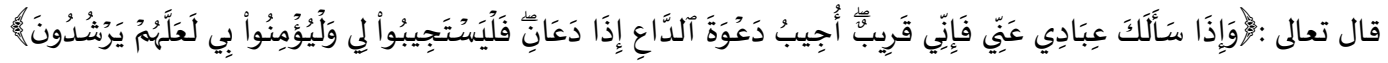

[البقرة:

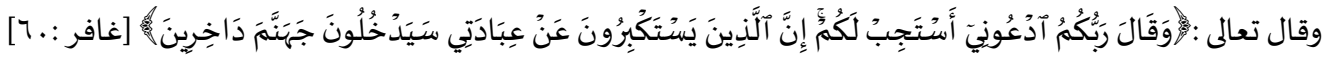

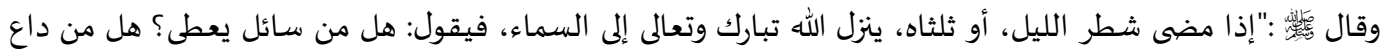

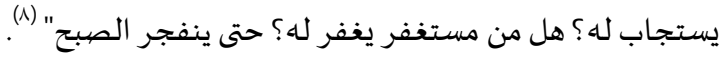
وهذا يعني أن المسجد بناء للروح وغذاء لله.

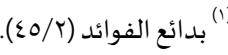

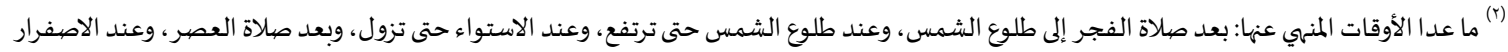

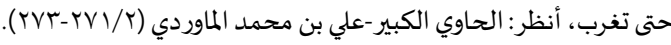

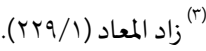

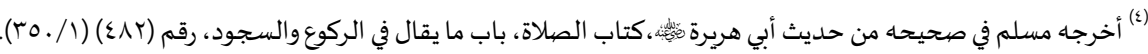

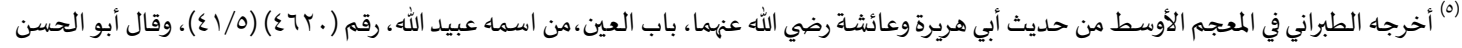

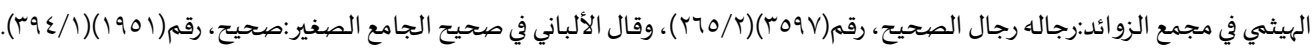

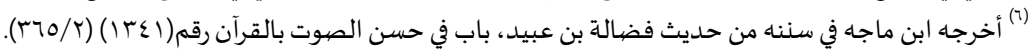

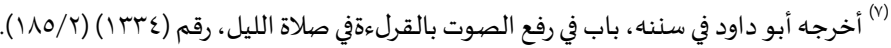

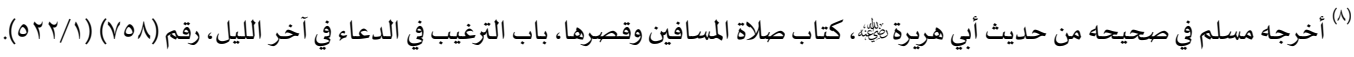


r. المسجد مركزللتفقيه والتعليم والتثقيف.

ففي المسجد يسمع الناس :"الخطب والدروس العلمية فيبدعون بوعي العقيدة الإسلامية، وفهم هدفههم من الحياة، وما أعده الله لهم في الدنيا والآخرة.

وفيه يتعلمون القرآن ويرتلونه، فيجمعون بين النمو الفكري والحضاري بتعلم القراءة، ودستور المجتمع، والنمو الروحي والارتباط بخالقهم. وفياء يتعلمون الحديث والفقه وكل ما يحتاجون من نظم الحياة الاجتماعية كما أراد الله ان ينظمها للإنسـان، ومن هداية الله وسنة رسوله" (1) فالمسجد "كان جامعة يتلقى فيها المسلمون تعاليم الإسلام وتوجيهاته... وتخرج منه كبار الصحابة وأئمة الهدى.

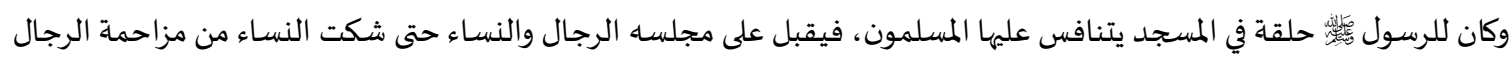

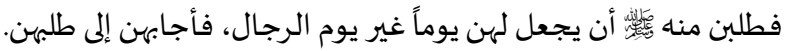

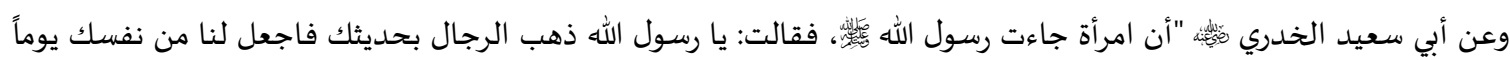

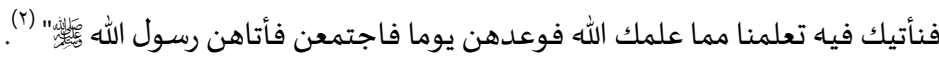

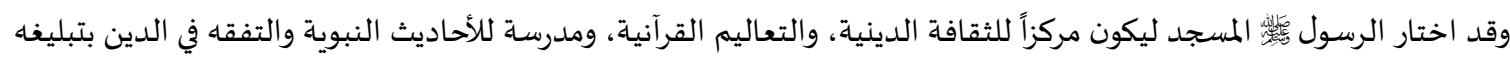
الوحي و توضيحه في خطب الجمعة ومجالس العلم، فكان المسجد بمثابة دار تعليم لذكر الله وتذكير الناس باه، والدعوة لاتباع دينه

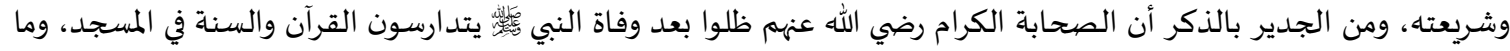

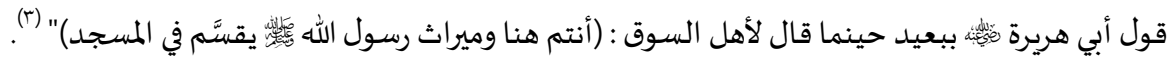
وهذا يعني أن المسجد بناء للعقل والفكر. r. المستجد وقاية من التطرف وحماية من الانحراف.

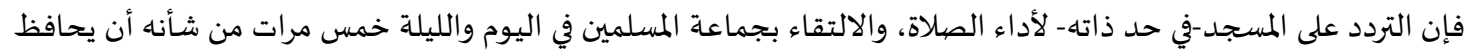

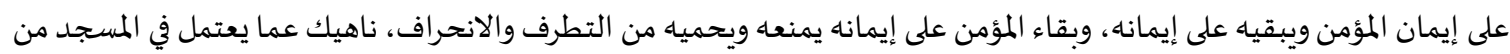

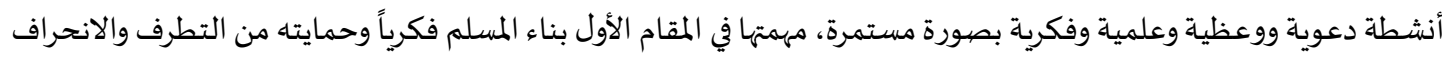

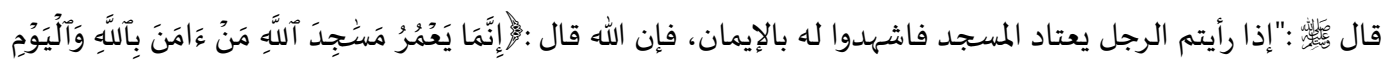

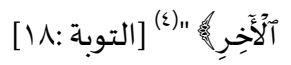

والإيمان من شأنه أن يمنع صاحباء من فعل ما يتعارض معاه عموماً ومن التطرف والانحراف الفكري خصيوصياً.

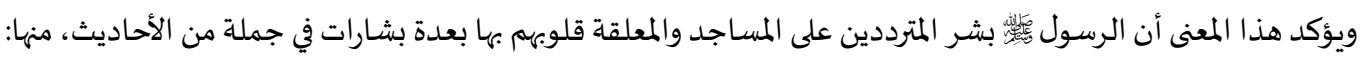

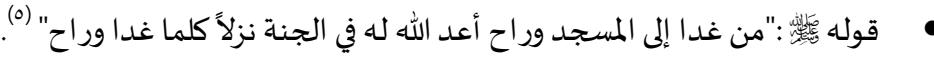

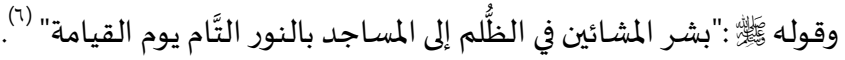

وقوله

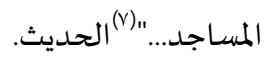

\section{ع. المسجد مركز لتصحيح المفاهيم ومواجهة الانحرافات.}

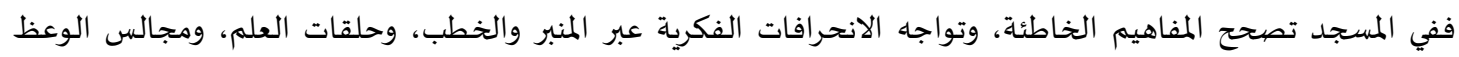

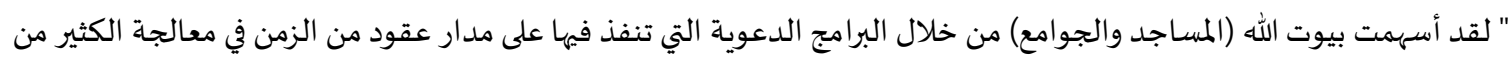
القضايا الدينية والاجتماعية سواء من خلال المحاضرات والكلمات الوعظية التي تعقب فروض الصلوات الخمس، أو من خلال منبر

(1) أصول التربية الإسلامية وأساليهها في البيت والمدرسة والمجتمع-عبد الرحمن النحلاوي، (ص ـ (1).

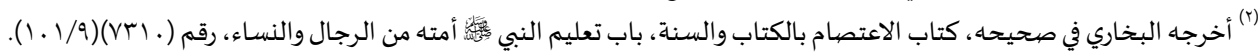

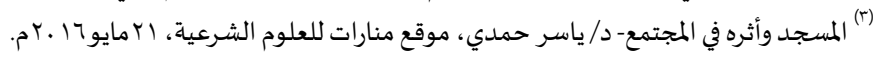

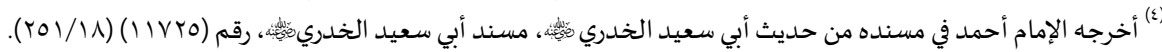

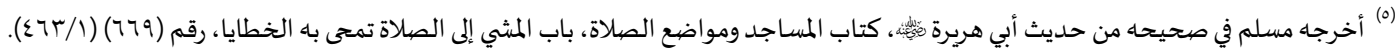

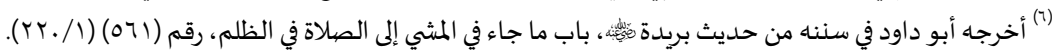

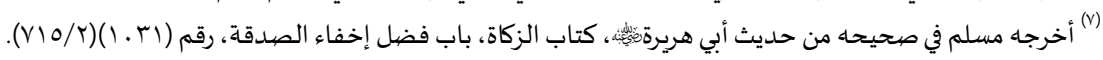


الجمعة الذي يلتقي فيه المسلمون للاستماع لخطبة الجمعة وأداء الصلاة.. ولقد كان لهذه البرامج دورٌ مهمّ في تسليط الضوء على كألى كثير

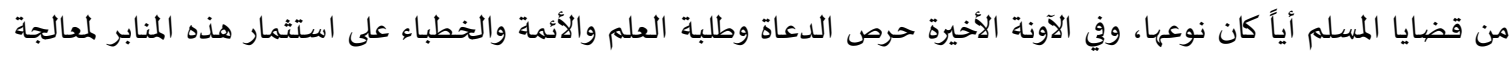
قضايا الانحراف الفكري والعقدي الذي بدا يظهر نتيجة أسباب كثيرة لعل من أبرزها: عدم الفهم الصحيح لتعاليم الإسلام وأحكامه.

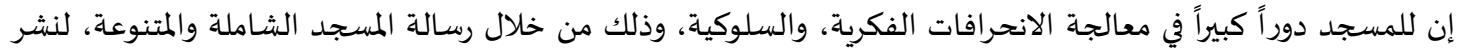

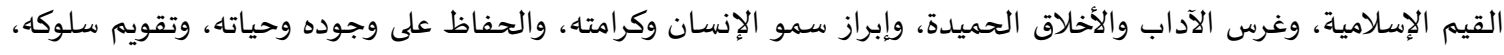

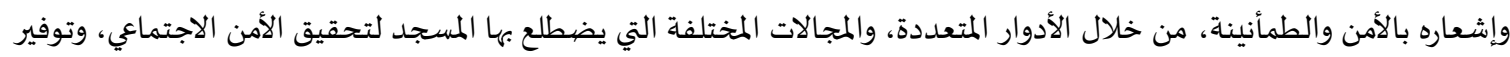

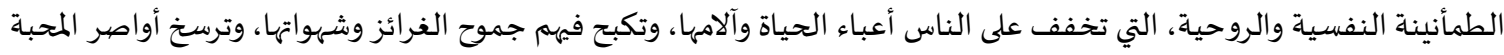

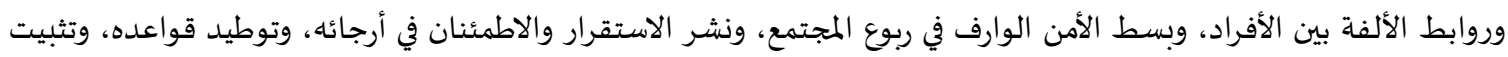
دعائماه.

والمسجد هو المكان المهيأ والقادر على [تصحيح]المفاهيم ومعالجة الانحراف الفكري؛ بنشر العقيدة ودفع الشبهات ومحاربة

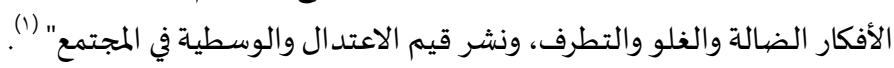

المبحث الثالث: المؤسسات التعليمية

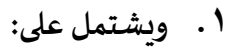

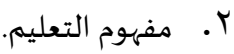

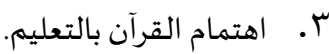

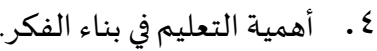

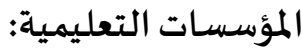

مفهوم المؤسسات: سبق الحديث عنه في اللغة والاصطلاح في مبحث (مصطلحات البحثث) عند الحديث عن مصطلح (المؤسسات) بما يغني عن إعادته هنا.

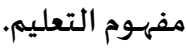

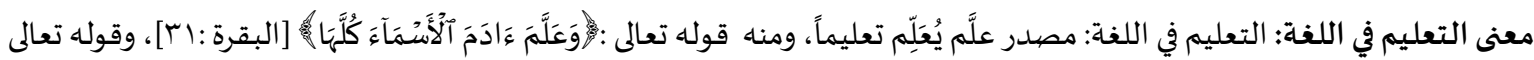

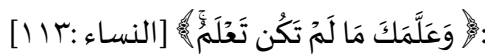

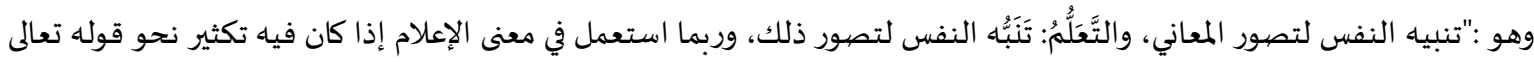

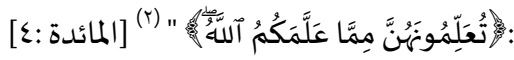

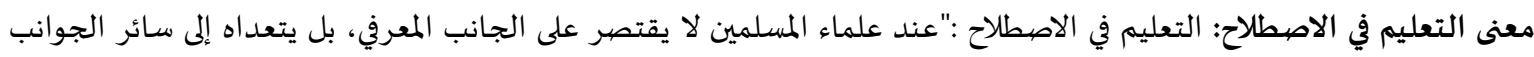

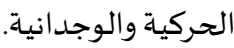
ويعرف: بأنه العملية المنظمة التي يمارسها المعلم بهدف نقل ما في ذهنه من معلومات ومعارف إلى المتعلمين الذين هم بحاجة إلى تلك

وفي التعليم تجد أن المعلم يرى أن في ذهنه مجموعاة من المعارف والمعلومات ويرغب في إيصالها للمتعلمين لأنها يرى أنهم بحاجة إلهيها

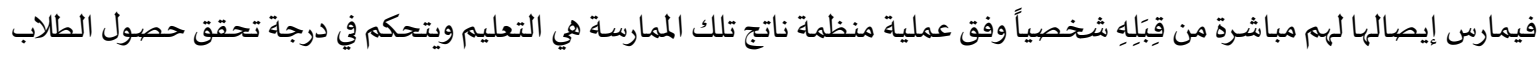

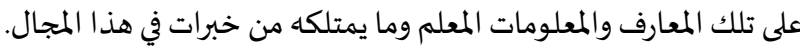

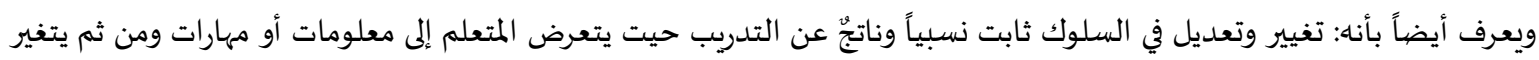
سلوكها أو يتعدل بتأثير ما تعرض لهانه

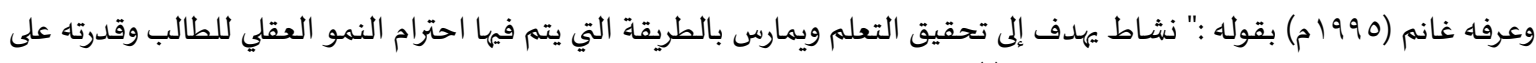

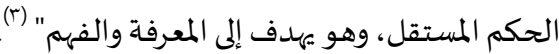

$$
\begin{aligned}
& \text { (1) ورقة عمل (دور المسجدد في الوقاية من التطرف)-جمعان بن حمود العصيمي، (ص)م). }
\end{aligned}
$$

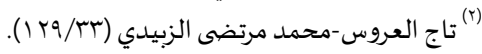

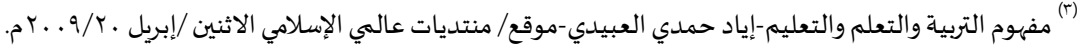


مفهوم مصطلح المؤسسة التعليمية كمركب وصفي.

المؤسساة التعليمية كمركب وصفي هي:"عبارة عن مكان أو موقع يتم فياه التقاء فئات مجتمعية مختلفة الأعمار ، ويتم فيها تعليمههم وتزويدهم بالكثير من المعلومات المختلفة حسب نوع هذه المؤسسة التعليمياة، وتتكون هذه المؤسسة التعليمية من أعضياء الهيئة

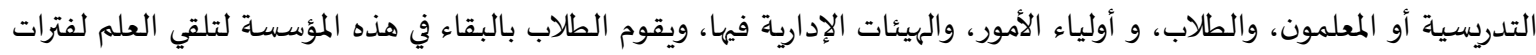

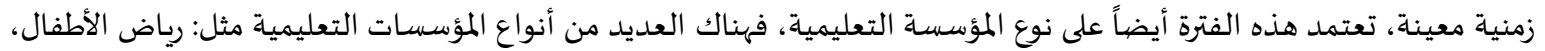

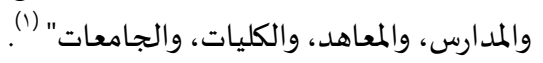

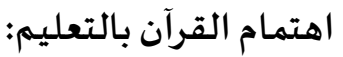

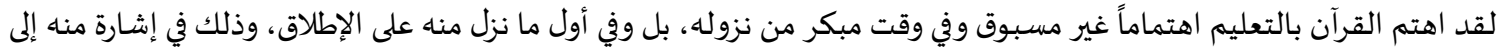

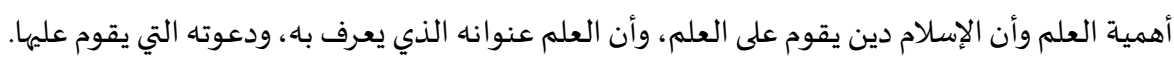

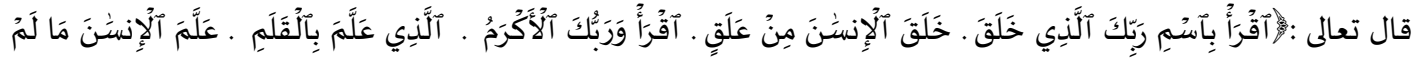

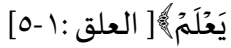

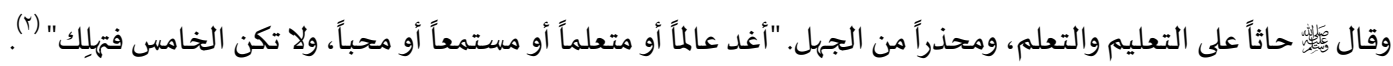

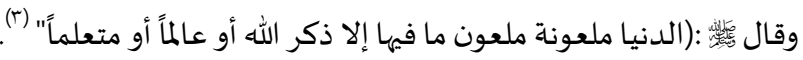

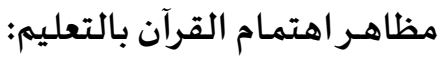

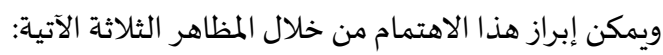

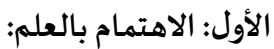

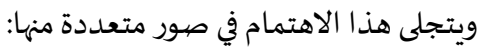

1. الأمر بالقراءة.

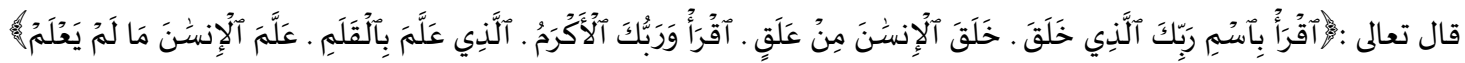

[0-1:العلق :

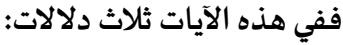

الأولى: الدلالة على أهمية القراءة في تحصيل العلم واكتساب المعرفة.

الثانية: الدلالة على أهمية العلم في بناء العقل والفكر وتحصينهما.

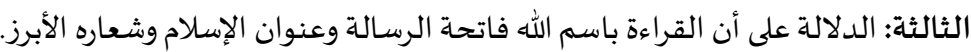

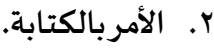

فإنها من أهم الوسائل لتوثيق الفكر الصحيح ونشره، والتصدي للفكر الفاسد ودحره، فهي وسيلة مزدوجة لنشر الفكر

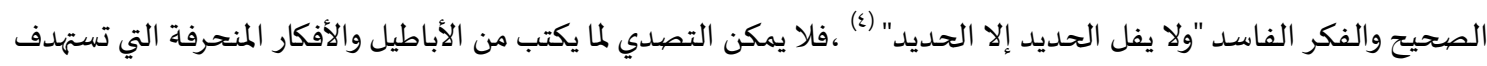

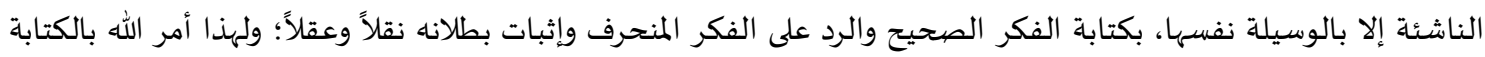

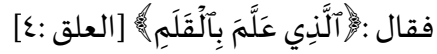

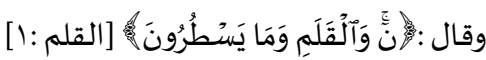

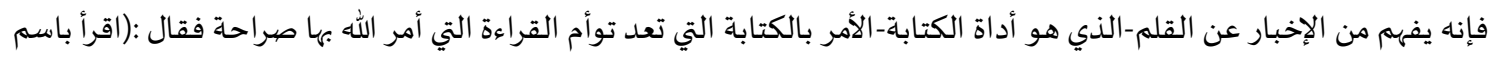

ربك الذي خلق)، والأمر بالقراءة أمر بالكتابة.

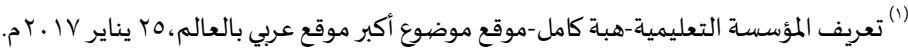

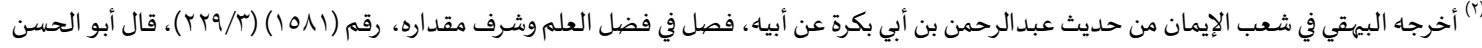

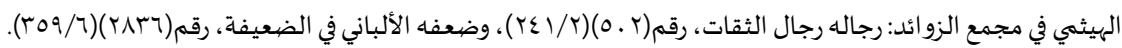

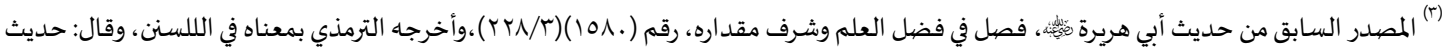

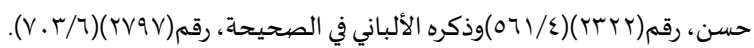

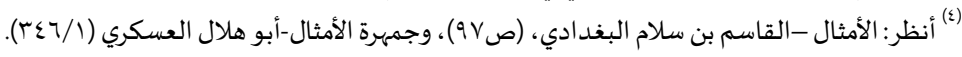

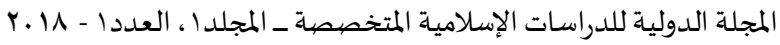


وهذا ما فهمه الرسول

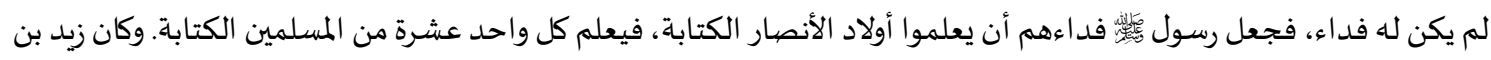

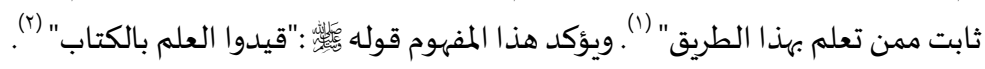

فهناك الكثير من الآيات القرآنية التي تتضمن الأمر بالعلم مقرونا بموضوعات تجب على الناس معرفتها يعلمهم الله إياها ويطالههم

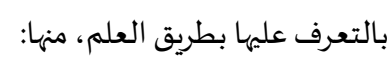

قوله

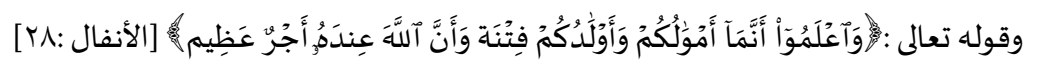

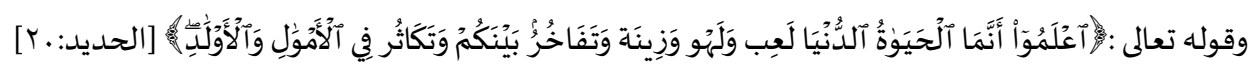

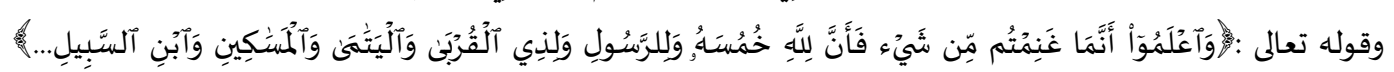

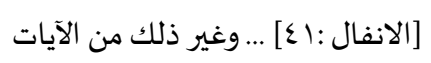

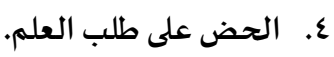

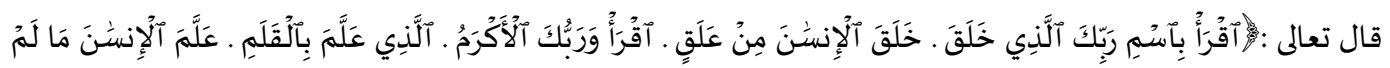

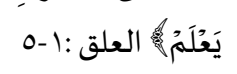

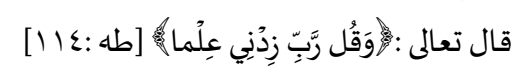

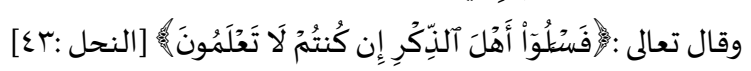

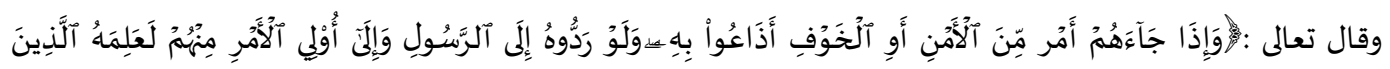

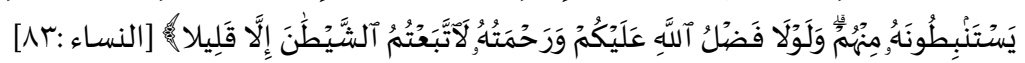

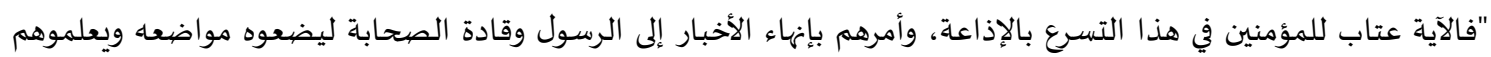

محامله" (r) مالاية

ه. الإشادة بالعلم والعلماء وطلاب العلم.

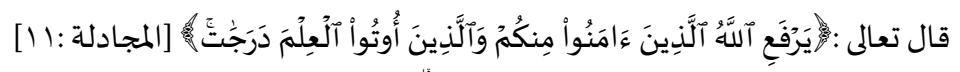

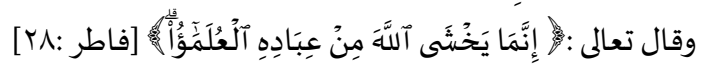

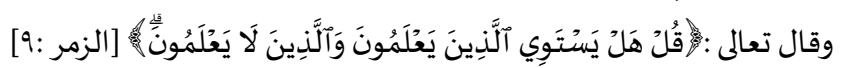

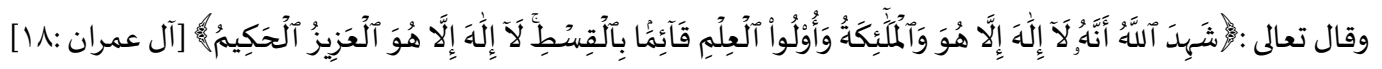

T. النهي عن القول بغيرعلم.

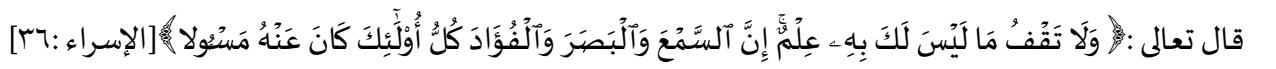

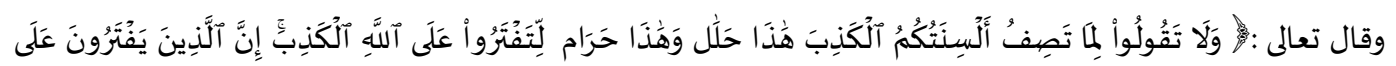

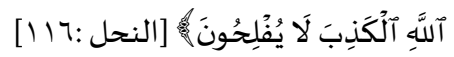

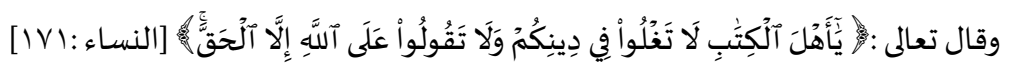

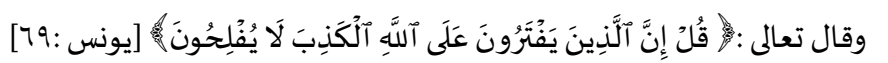

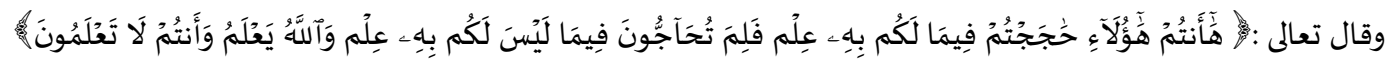

[77: [آل عمران ]

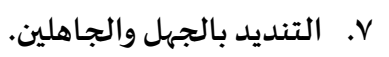

قال تالِ

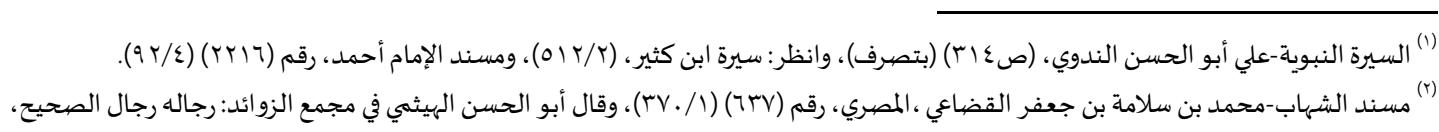

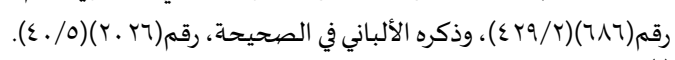

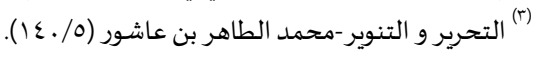




\section{[قال}

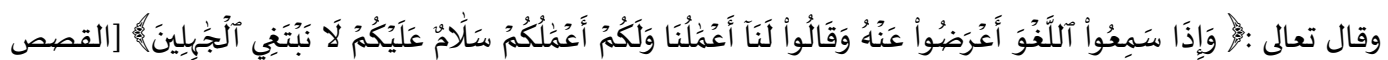



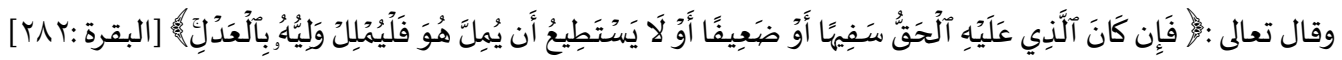

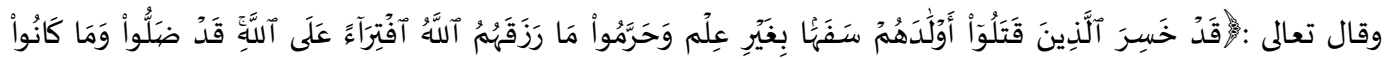

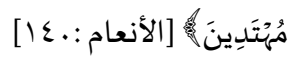

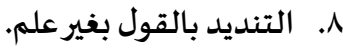

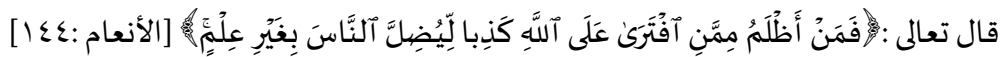

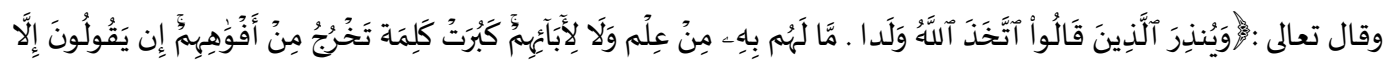

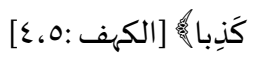

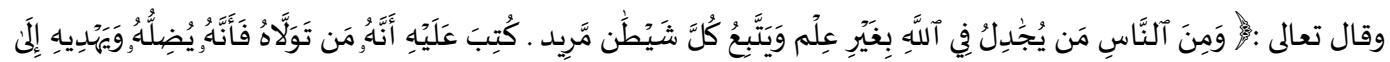

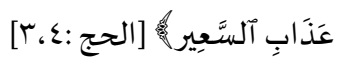

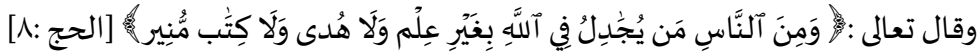

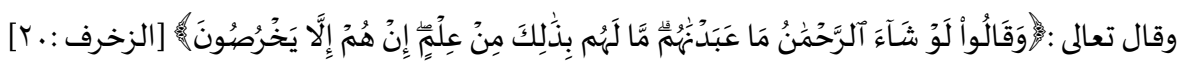

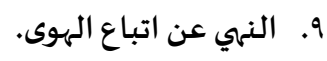

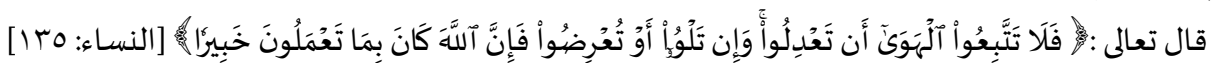

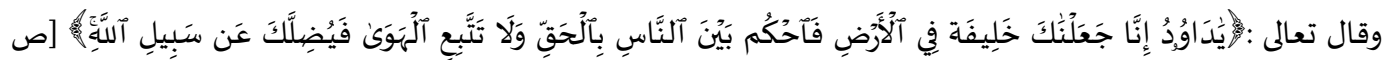

[r]:

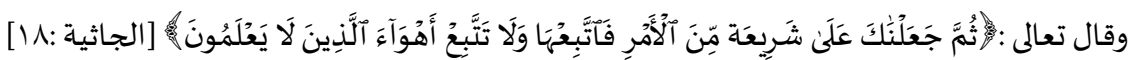

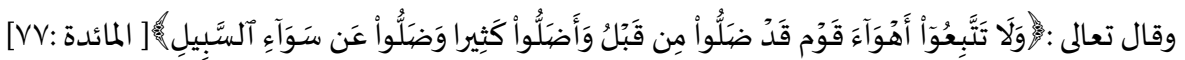

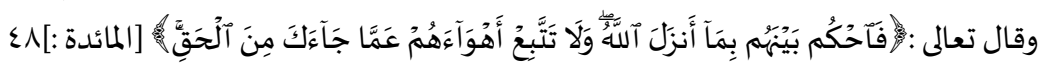

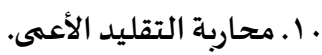
وهو من أخطر الآفات والملوثات العقلية والأمراض والفيروسات الفكرية التي جاء الإسلام لمحاربتها وإنقاذ الناس من شرها، وتحريرهم من عبوديتها ووقايتهم من أمراضها. والتقليد الأعهى :أن تغمض عينك وتتبع غيرك، وأن تلغي عقلك وتغلّبِ جهلك وهذا ما أشار إليهاه القرآن الكريم في كثير من آياته منها:

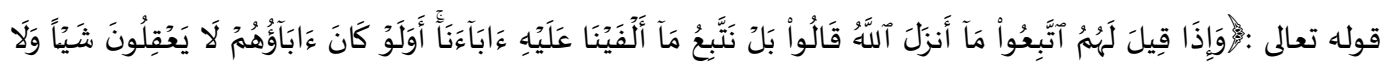

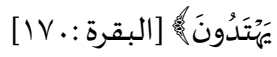

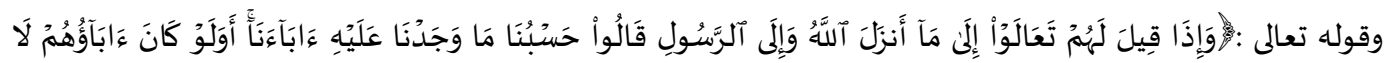

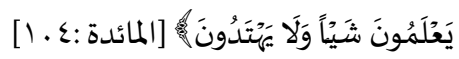

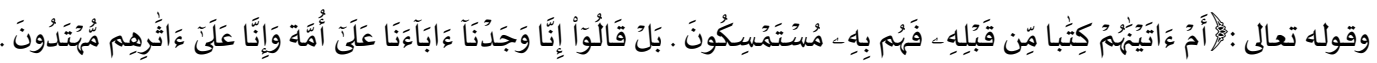

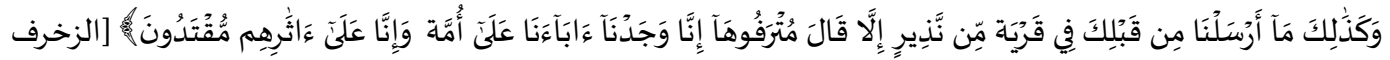

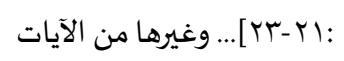

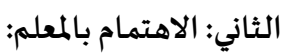

$$
\begin{aligned}
& \text { وكما اهتم القرآن بالعلم اهتم بالمعلم وذلك على النحو الآتي: } \\
& \text { • • عليم الله له وفتحاه عليه. }
\end{aligned}
$$

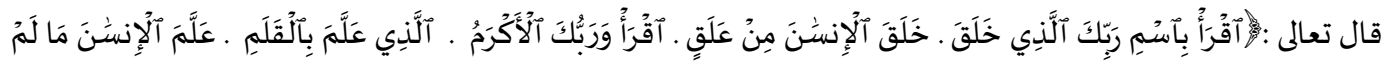

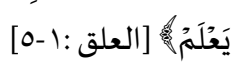

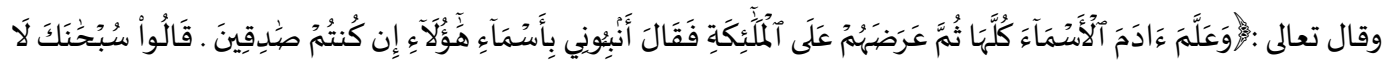

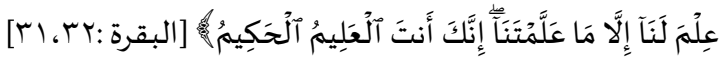




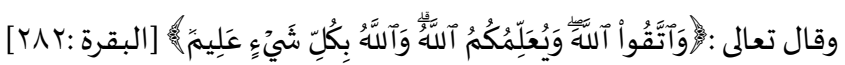

$$
\text { رفع درجتاه وقدره على من سواه. }
$$

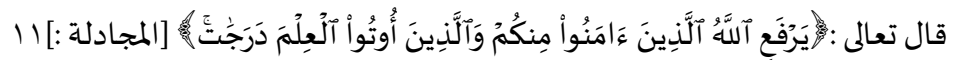

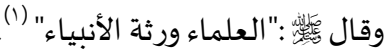

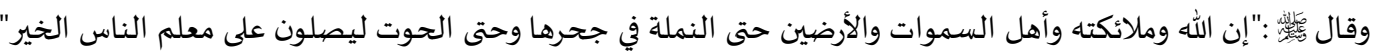

الثالث: الاهتمام بطرق وأساليب التعليم.

فقد اشـار القرآن الكريم إلى كثير من الطرق التعليمية المتعددة والمتنوعة منها:

$$
\text { التعليم بالتجربية. }
$$

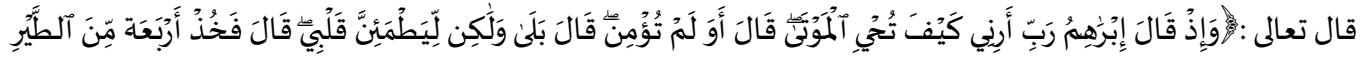

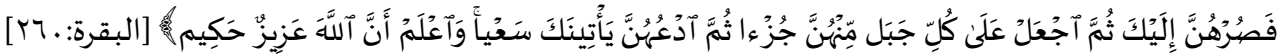

$$
\text { التعلم بالتقليد. }
$$

مثل تقليد قابيل الغراب في مواراة جثة أخياء هابيل بعد قتلها.

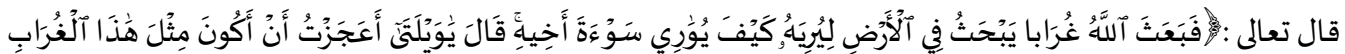

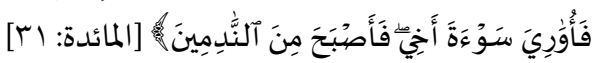

$$
\text { وهي كثيرة جداً منها: التعليم بضرب الأمثال. }
$$

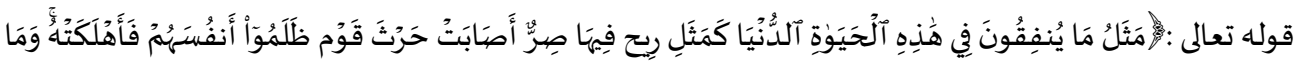

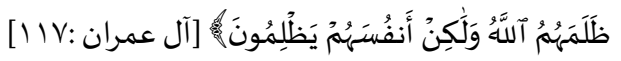

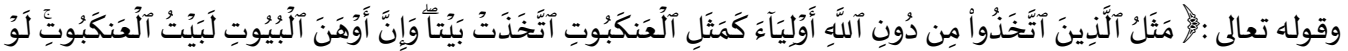

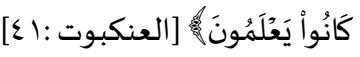

$$
\begin{aligned}
& \text { التعليم بالقصة. }
\end{aligned}
$$

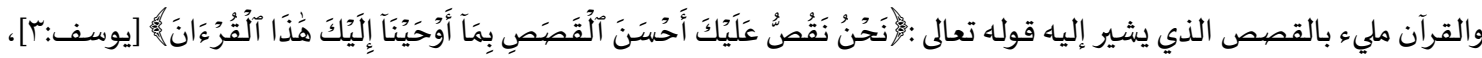

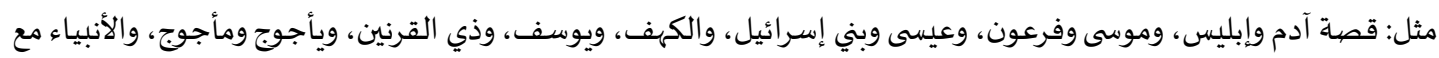

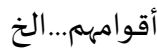

$$
\text { التعليم بالقدوة الحسنة. }
$$

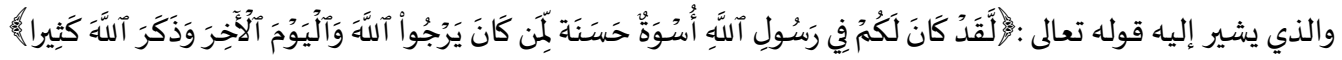

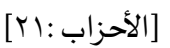

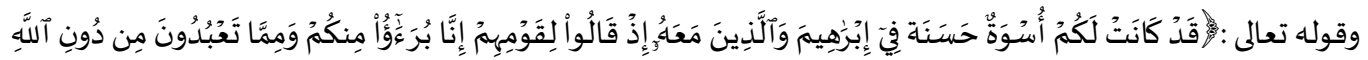

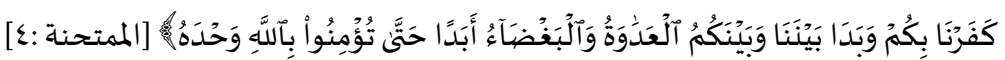

$$
\text { • التعليم بالحوار والمناقشـة. }
$$

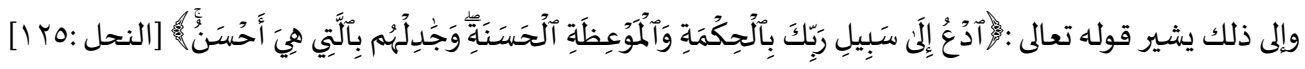

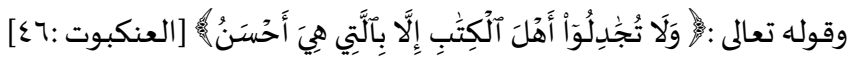

$$
\begin{aligned}
& \text { والقرآن مليء بالحوارات ومن أبرزها: حوار الأنبياء مع أقوامهم وما أكثرها. }
\end{aligned}
$$

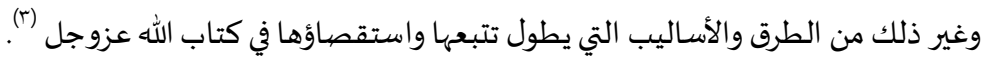

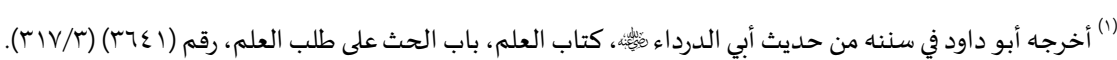

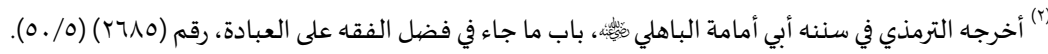

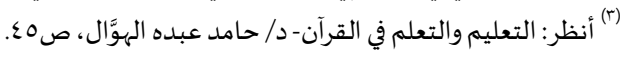




\section{أهمية التعليم ومؤسساته في بناء الفكر:}

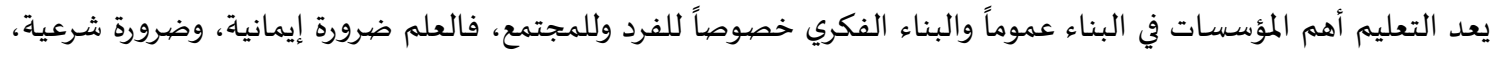

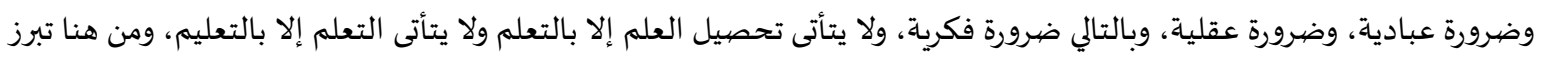

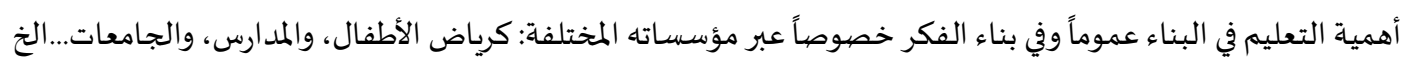

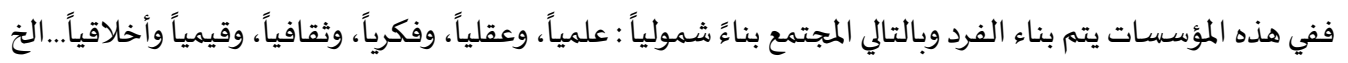

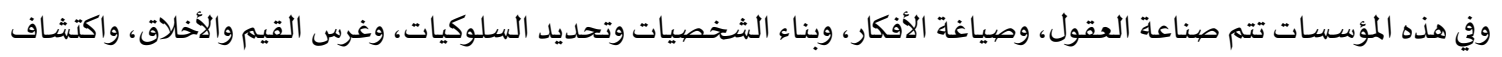

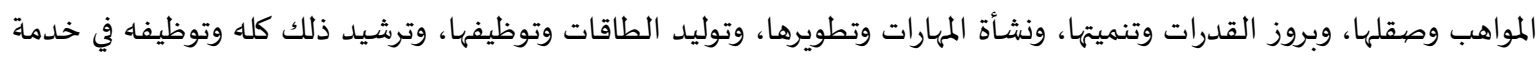
الإسلام والمسلمين وأبناء الإنسانية أجمعين.

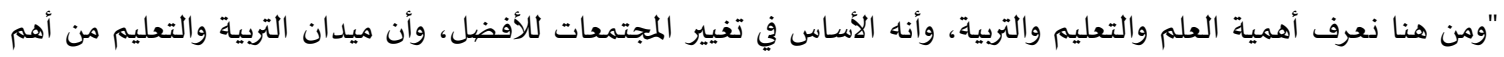

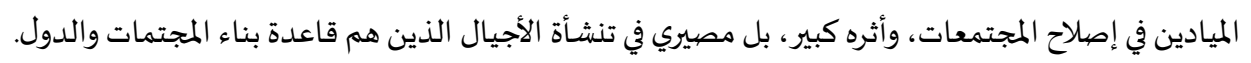

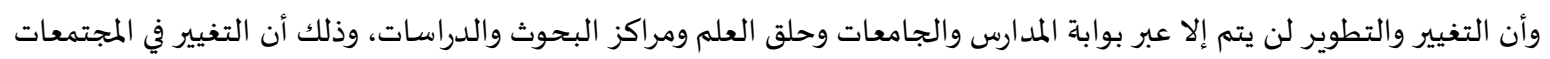

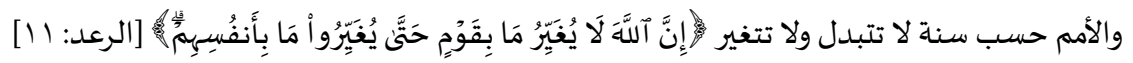

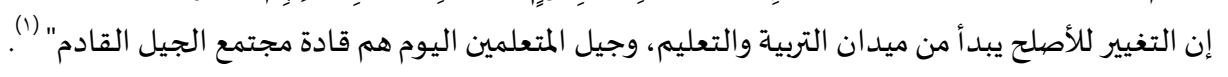

$$
\begin{aligned}
& \text { المطلب الرابع:المؤسسـات الدعوية }
\end{aligned}
$$

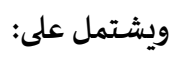

$$
\begin{aligned}
& \text { 1. مفهوم الدعوة. }
\end{aligned}
$$

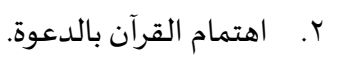

$$
\begin{aligned}
& \text { r. r. أهمية الدعوة في بناء الفكر. }
\end{aligned}
$$

المؤسسات الدعوية:

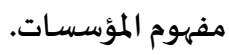

سبق الحديث عنه لغةًً واصطلاحاً في مبحث (مصطلحات البحث) عند الحديث عن مصطلح (المؤسسات) بما يغني عن إعادته هنا. مفهوم الدعوة: معنى الدعوة في اللغة: الدعوة في اللغة: مصددر: دعا يدعو دعوة.

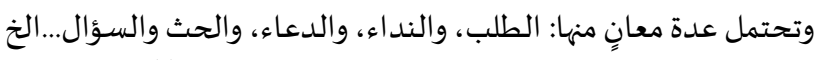

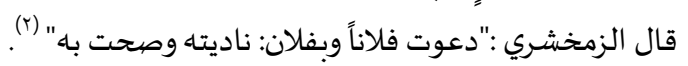

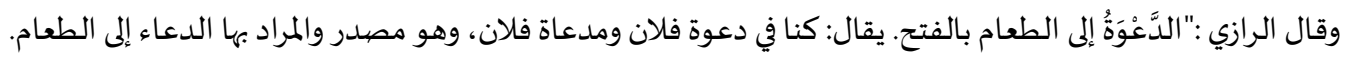

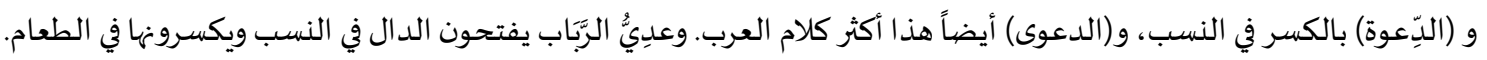

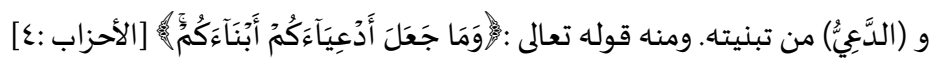

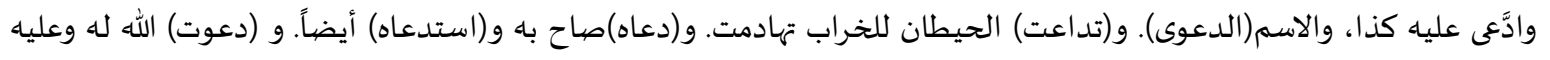

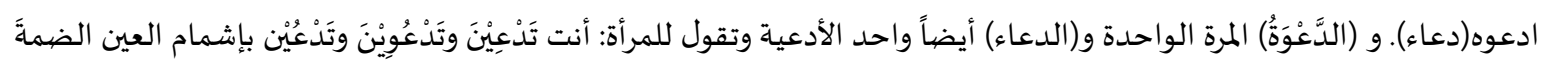

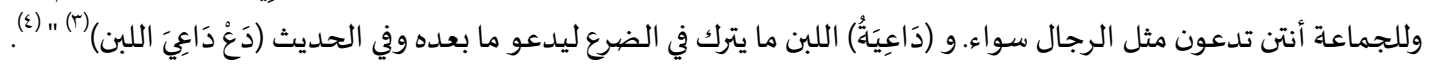

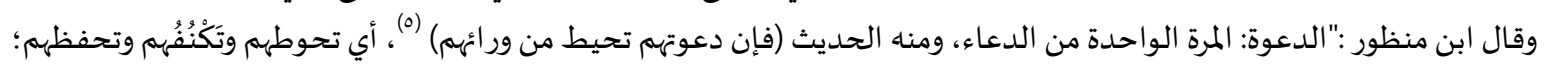

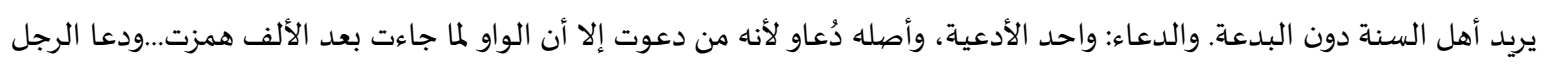

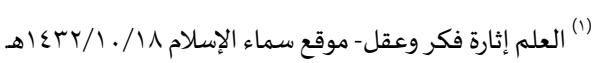

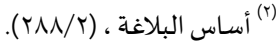

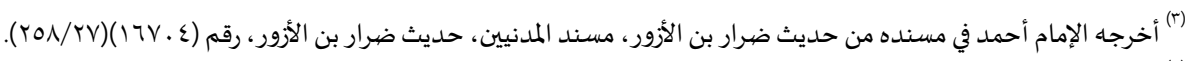

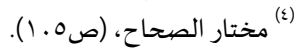

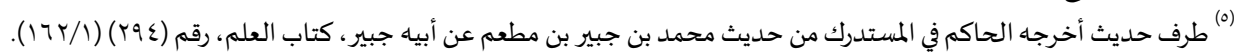


دعواً ودعاءً: ناد اه، والاسم الدعوة، ودعوت فلاناً أي صحت به واستدعيته...والدعاة: قوم يدعون إلى بيعة هديً أو ضلالة، واحدهم داع.

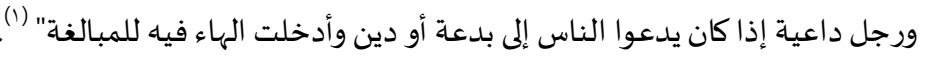

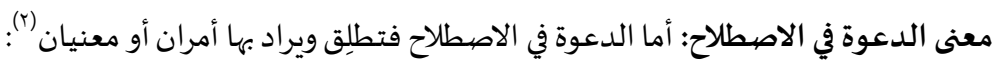

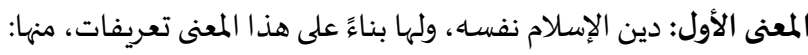

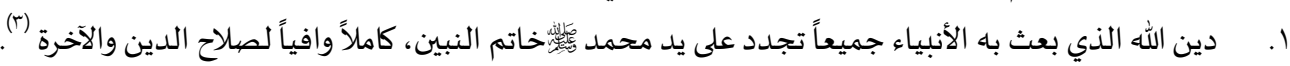

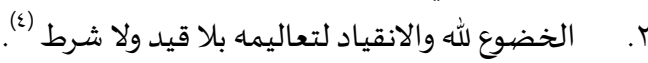
والمعنى الثاني: عملية نشر الإسلام وتبليغه وهذا المعنى هو المقصود هنا (o) ولها بناءً على هذا المعنى تعريفات التهات كثيرة، منها:

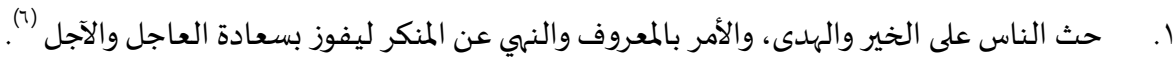

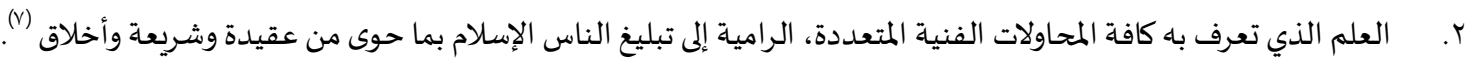

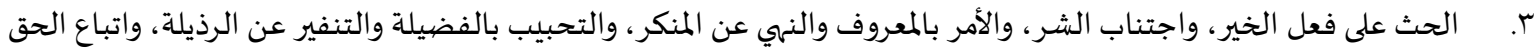
ونبذ الباطل)

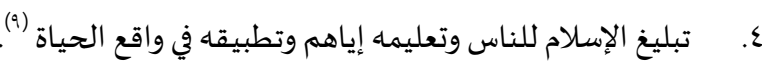

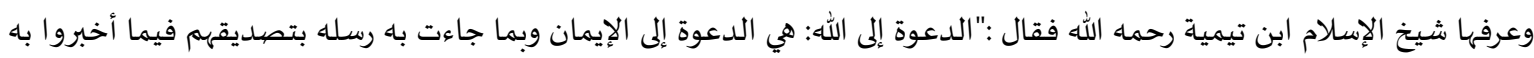

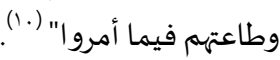

\section{اهتمـام القرآن بالدعوة:}

إن الدعوة إلى الله: نشر للإسلام، وتعريف باه وتجديد لله، وتفقيه في الدين، وتثقيف للمسلمين وتصحيح للعقائد، وترسيخ للإيمان، ونشر للعلم، وقضاء على الجهل، ونشر للهداياة، وإنقاذ من الغواياة، ومحاربة للبدع والضالالات، وتفنيد للشبهات، وتقييد للشهوات، وتصدٍٍ للانحرافات والخرافات، وإصلاح للمجتمعات، ووقاية للشباب من التطرف والإرهاب، والانحراف الفكري والعقدي، ولتهري، وحماية للدين من التغيير والتبديل...الخ وتهرئ

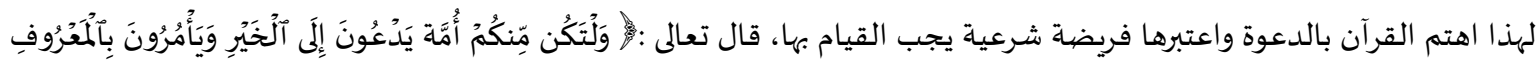

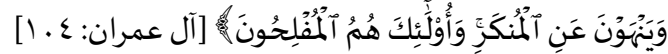

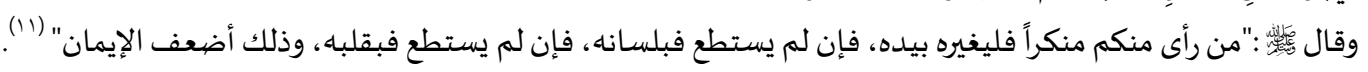
مظاهر اهتمام القرآن بالدعوة. ويمكن إبراز هذا الاهتمام في المظاهر الآتية:

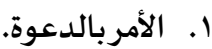
وذلك في كثير من الآيات القرآنية والأحاديث النبوية التي تدل على أن الدعوة فريضة شرعية على سبيل الكفاية يجب أن يكون في الأمة

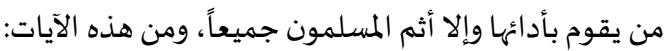

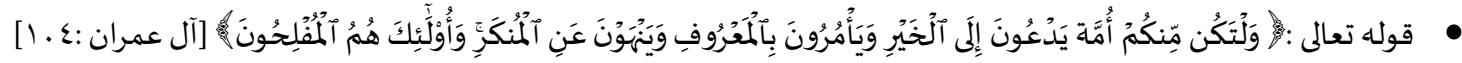

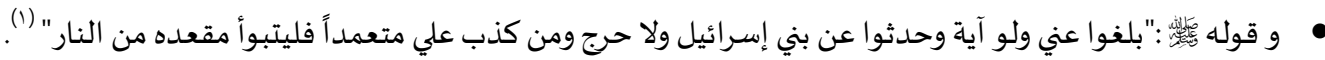

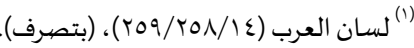

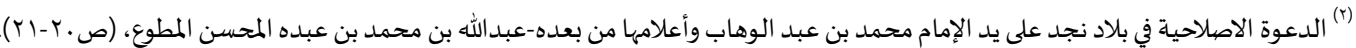

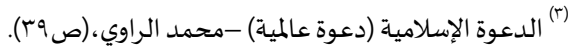

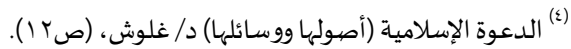

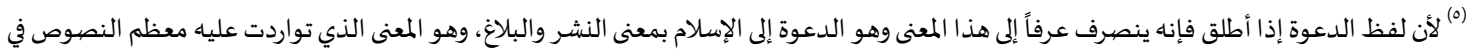

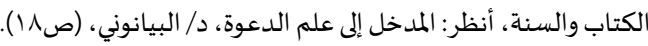

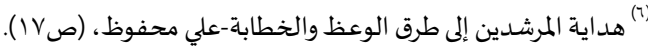

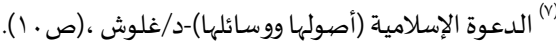

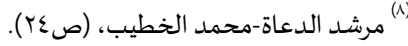

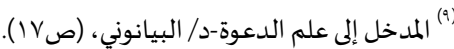

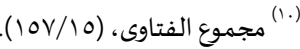

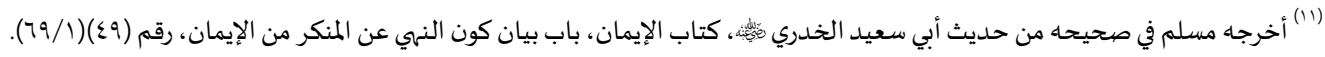




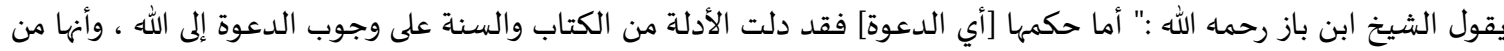

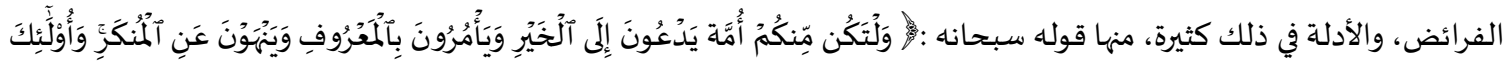

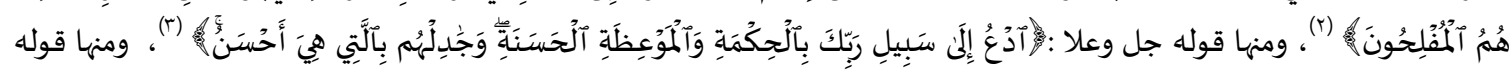

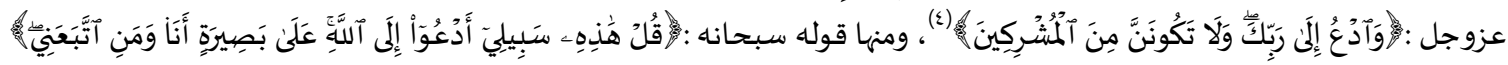

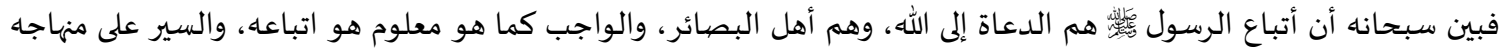

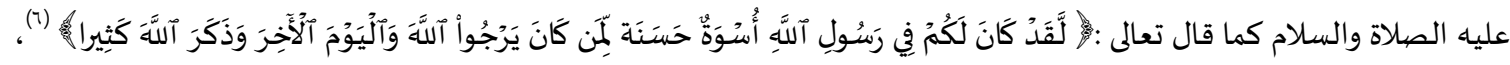

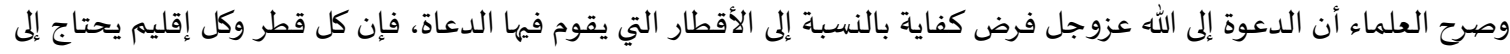

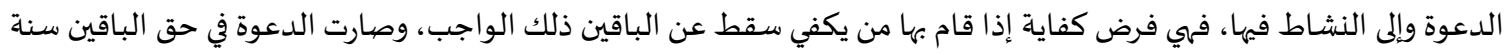
مؤكدة، وعملاً صالحاً جليلاً.

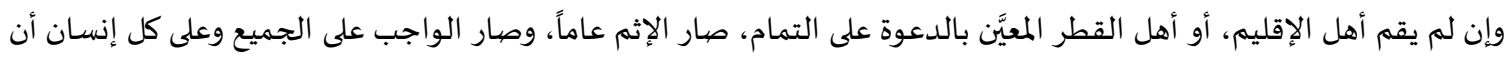

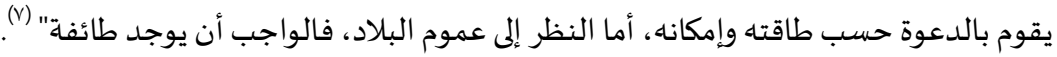

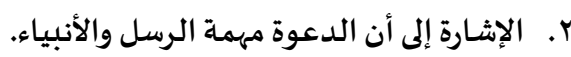

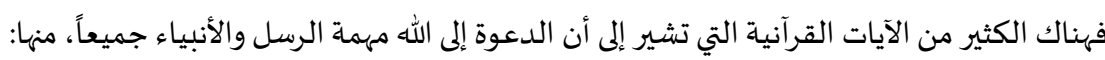

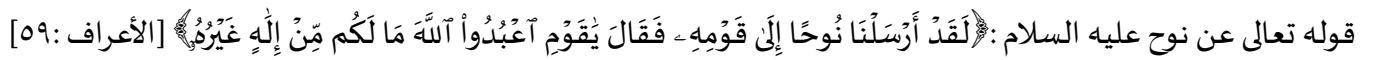

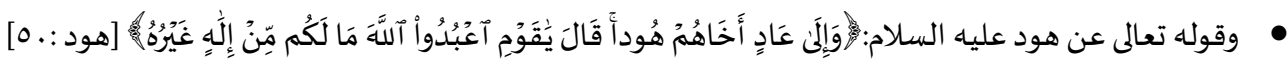

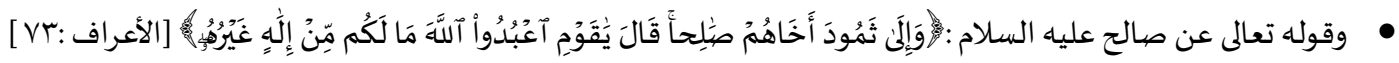

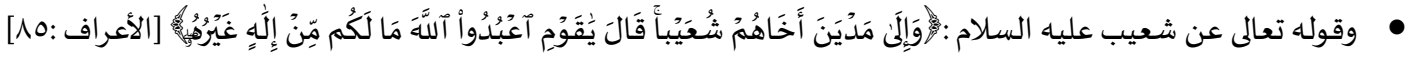

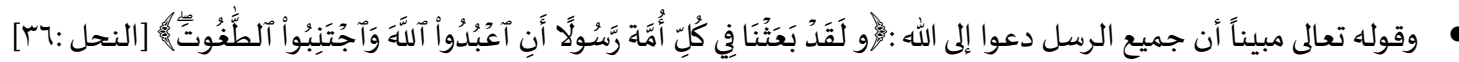

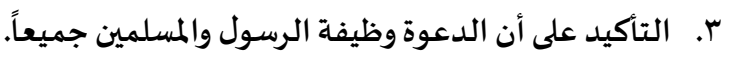

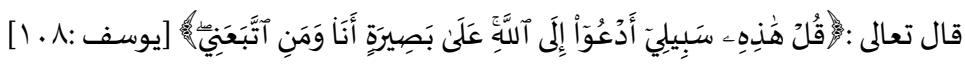

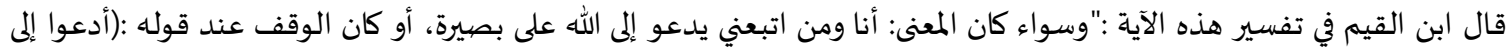

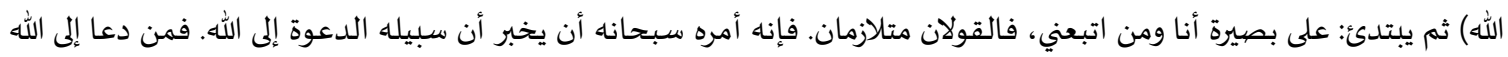

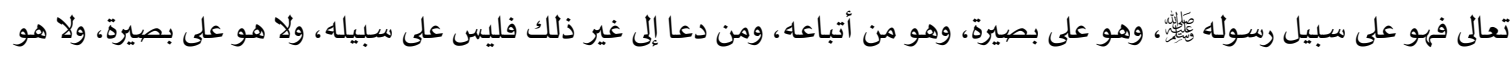

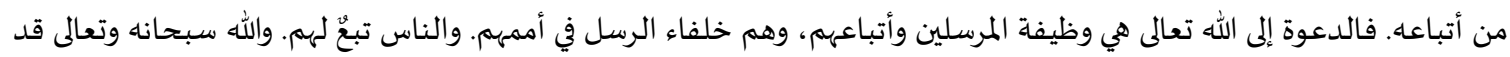

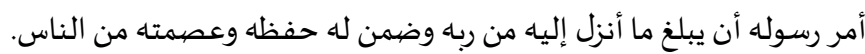

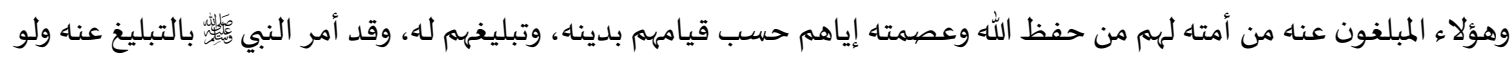

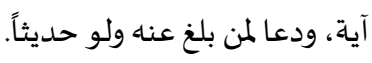

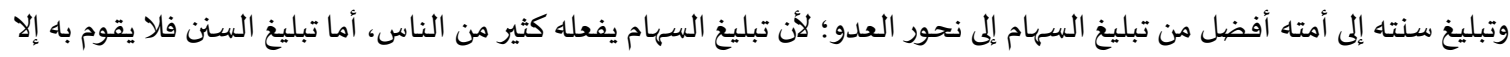

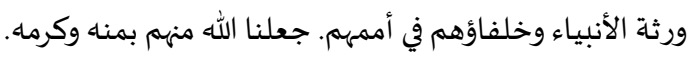

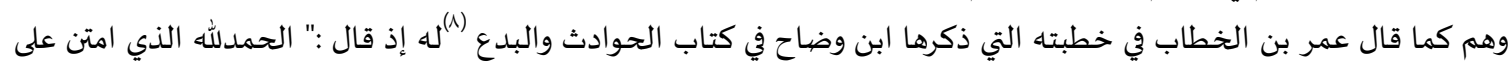

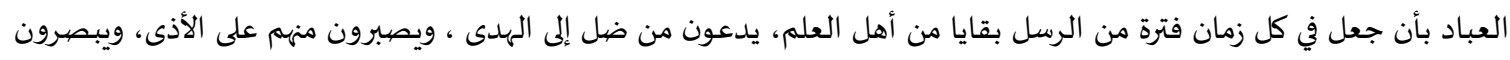

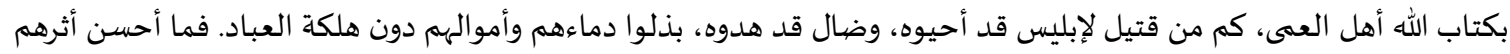

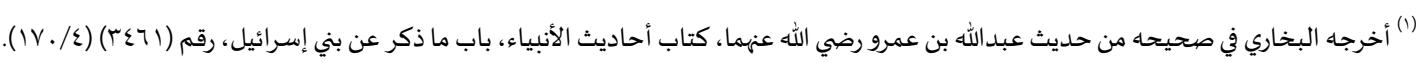

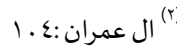
|ro: النحران:(r) NV:

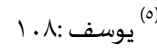
Yl: (1) الأحزاب (1)

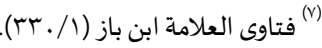

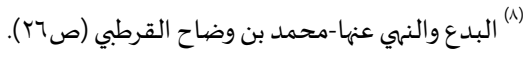




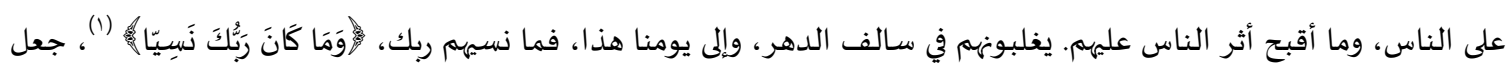

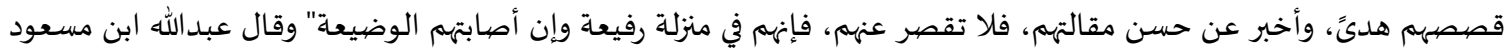

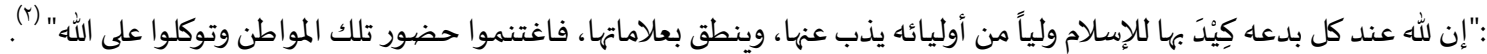

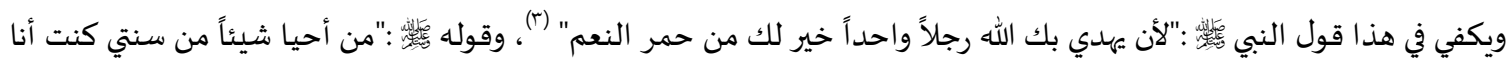

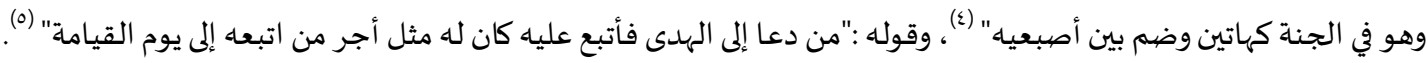

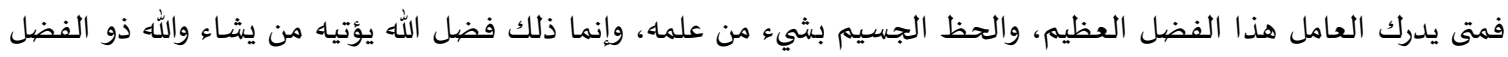

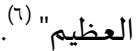

ع. الإشادة بالعمل الدعوي والثناء على الدعاة.

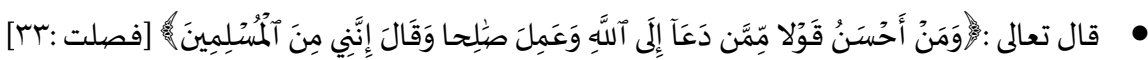

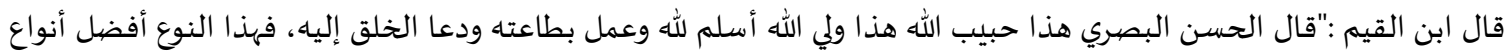

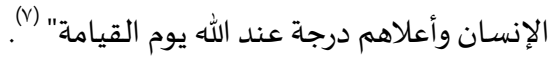
وقال السعدي :"هذا استفهام بمعنى النفي المتقرر أي: لا أحد أحسن قولاًا . أي: كلاماً وطريقةً، وحالةً (ممن دعا إلى اللهاه بتعليم

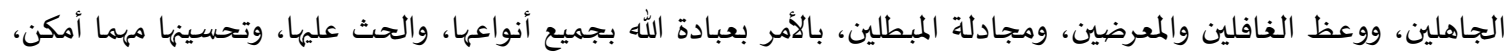

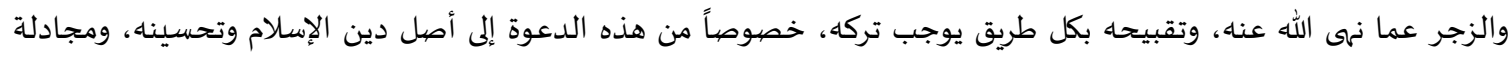

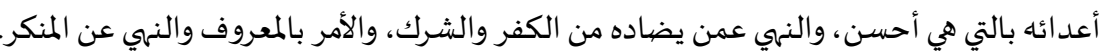

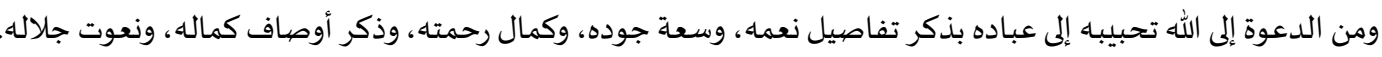

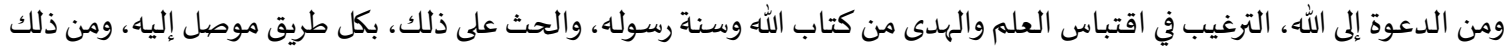

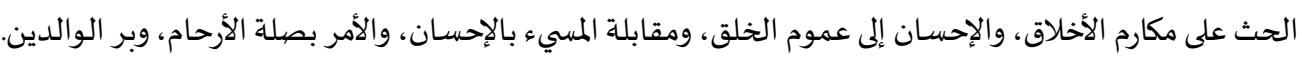

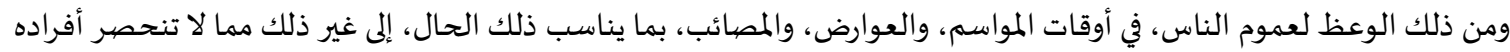

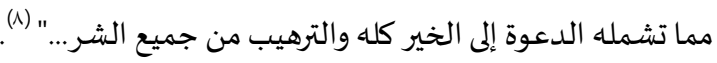

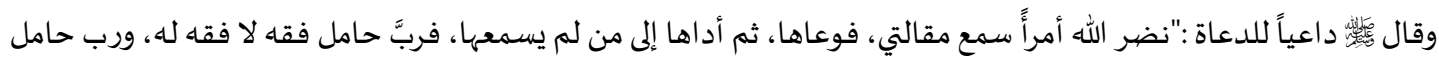

$$
\begin{aligned}
& \text { فقدٍ إلى من هو أفقه منه" (9). } \\
& \text { 0. تحديد طرق وأساليب الدعوة. }
\end{aligned}
$$

وهذا من أهم وأبرز المظاهر التي تؤكد اهتمام القرآن بالدعوة إلى الله تعالى.

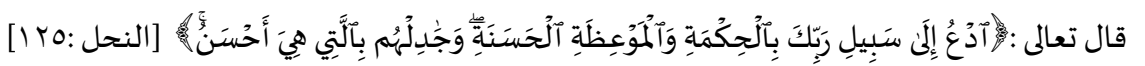

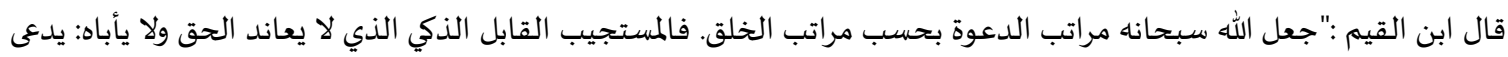
بطريق الحكمة.

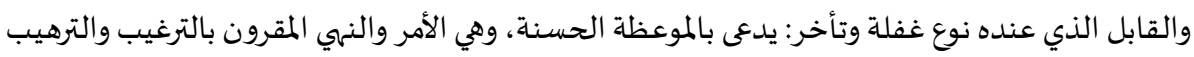
والمعاند الجاحد: يجادل بالتي هي أحسن" (. ").

(1)

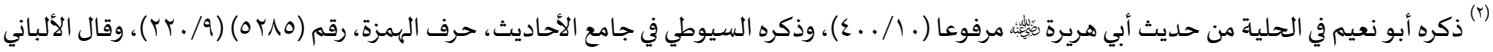

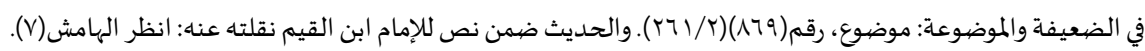

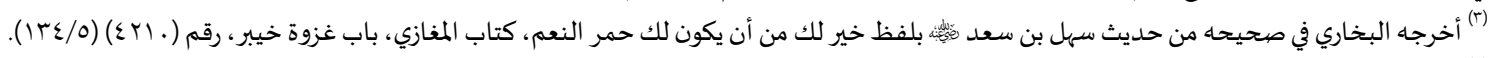

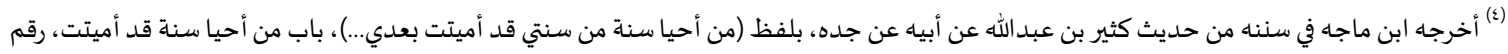

(VT/M) (YI.)

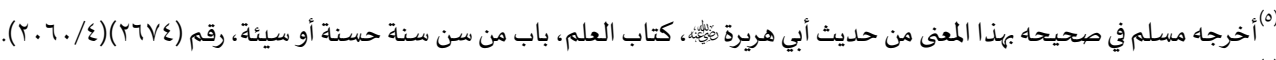

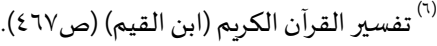

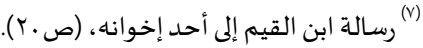

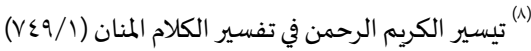

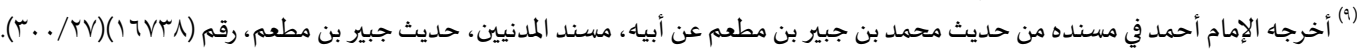

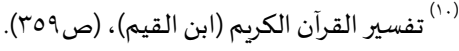


وقال أيضاً :"فذكر سبحانه مراتب الدعوة وجعلها ثلاثة أقسام بحسب حال المدعو، فإنه إما أن يكون طالباً للحق راغباً فيه محباً له

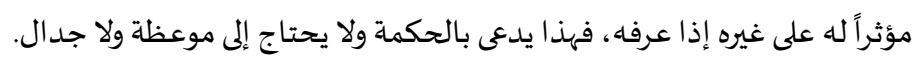

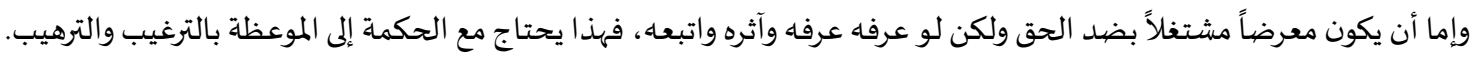

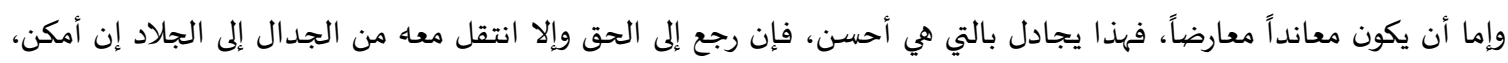

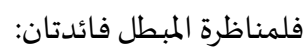

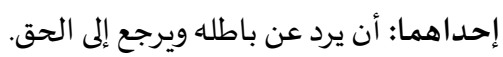

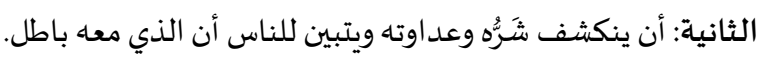

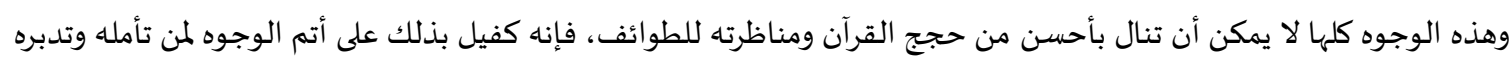

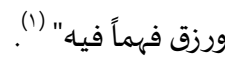

أهمية الدعوة في بناء الفكر:

فقد تبين من خلال الحديث السابق عن اهتمام القرآن بالدعوة أن وظيفة الدعوة وهدفها الأول هو بناء المسلم بناء فكرياً شمولياً،

$$
\begin{aligned}
& \text { وتحصينه من الانحراف وحمايته من الاضطراب. } \\
& \text { فإن الدعوة كما سبق الحديث عنها: } \\
& \text { نشرُ للإسلام، وتعريف بهاه، وتجديدّ له. } \\
& \text { تفقيه في الدين، وتثقيف للمسلمين. } \\
& \text { • • •صحيح للعقائد، وتوضيح للشرائع، وبيان للشعائر. } \\
& \text { نشر للعلم، وقضاء على الجهل. } \\
& \text { ن نشر للهداية، وإنقاذ من الغواية. } \\
& \text { • • محاربة للبدع والضلالات. } \\
& \text { • ت تفنيد للشبهات. } \\
& \text { • تقييد للشهوات. } \\
& \text { تصديد للانحرافات والخرافات. } \\
& \text { • • إصلاح للمجتمعات، وتغيير للمنكرات. } \\
& \text { • • وقاية للشباب من التطرف والإرهاب، والانحراف الفكري والعقدي. }
\end{aligned}
$$

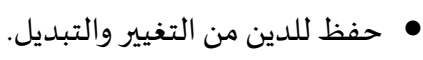

$$
\begin{aligned}
& \text { وغير ذلك... مما لا يقع تحت حصر. }
\end{aligned}
$$

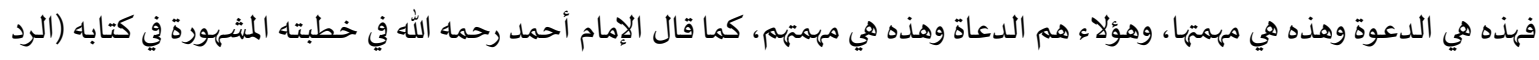

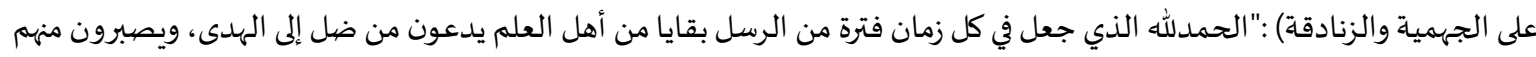

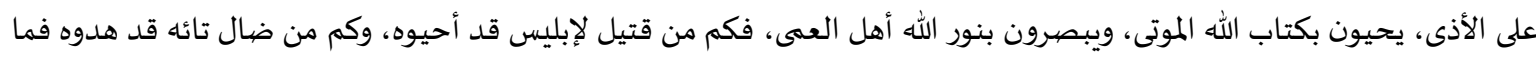

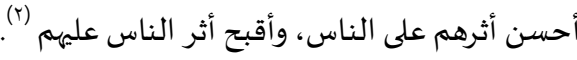

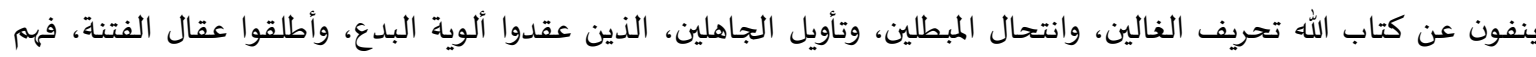

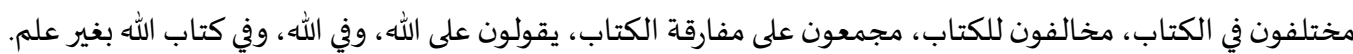

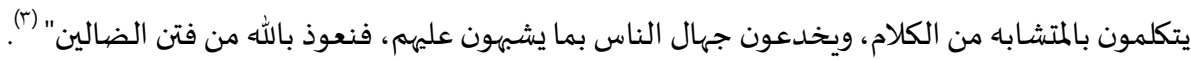

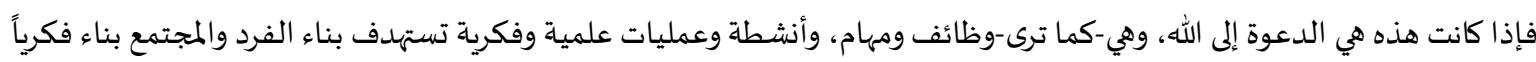

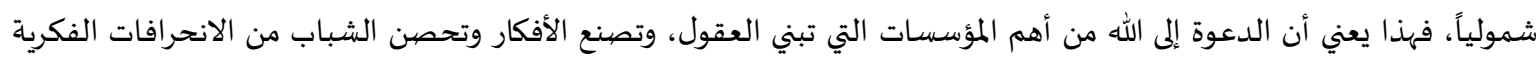

(1) الصهواعق المرسلة في الرد على الجهمية والمعطلة (ع/ع ا IVT).

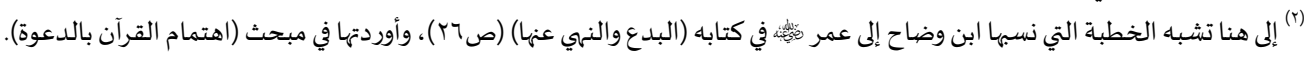

. (ص) (r) 
مظاهر أهمية الدعوة في بناء الفكر:

وبالإضافة إلى ذلك يمكن إبراز أهمية الدعوة في بناء الفكر من خلاءل المظاهر الآتية:

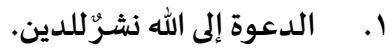

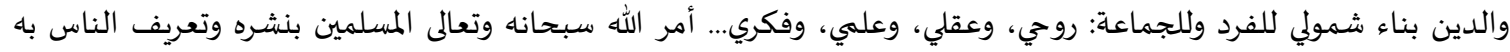

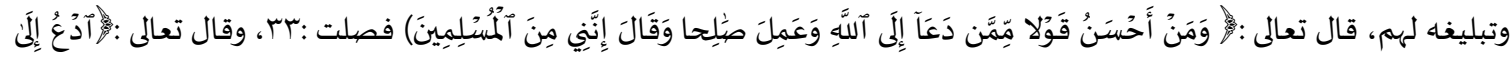

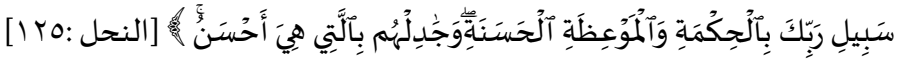

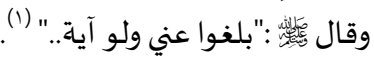
r. الدعوة إلى الله، تعليم وتفقيه وتثقيف.

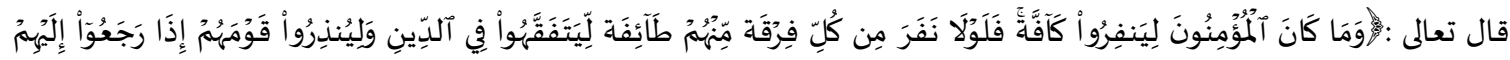

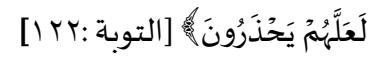

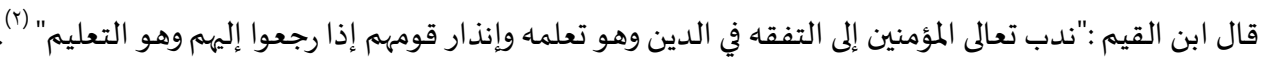

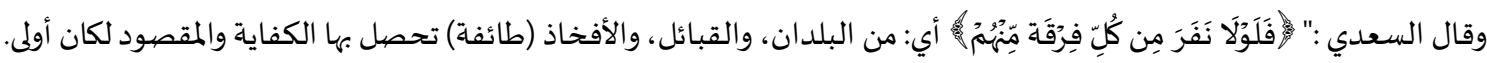
ثم نبه على أن في إقامة المقيمين منهم وعدم خروجهم مصالج لو خرجوا لفاتههم، فقال: (ليتفقهوا) أي: القاعدون (في الدين ولينذروا

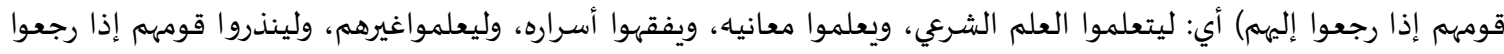

إليهم. ففي هذا فضيلة العلم، وخصوصاً الفقه في الدين، وأنه أهم الأمور، وأن من تعلم علماً فعليه نشره وبثه في العباد، ونصيحتهم فيه، فإن انتشار العلم عن العالم، من بركته وأجره الذي ينهى إليه" (").

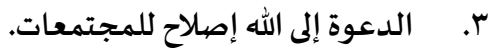

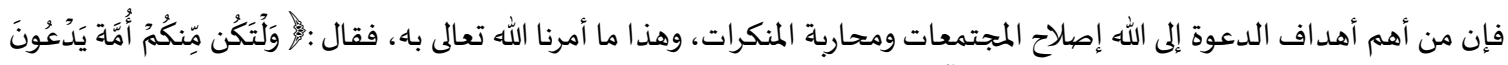

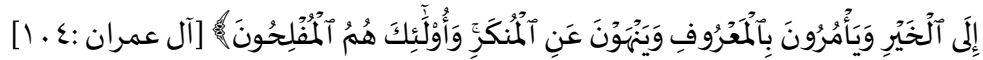

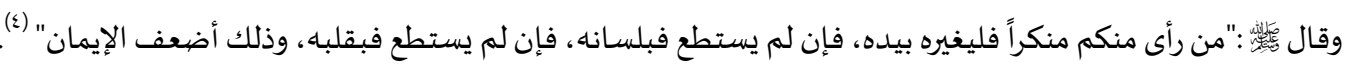
ع. الدعوة إلى الله هداية للناس.

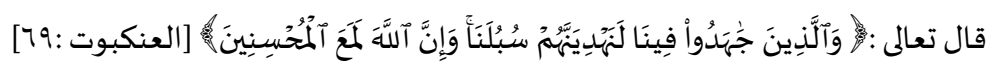

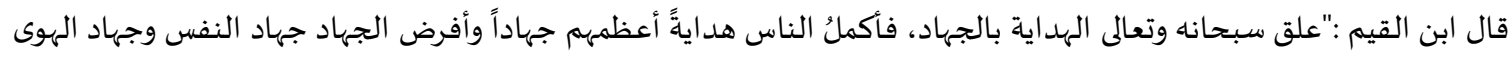

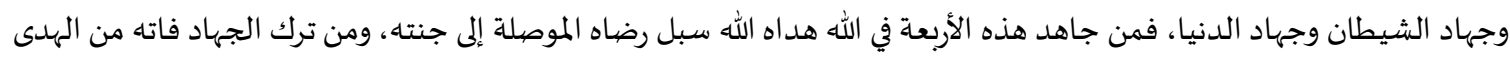
بحسب ما عطل من الجهاد" (0)

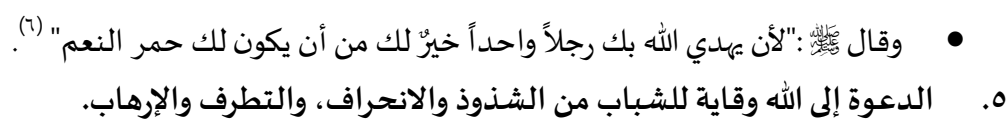

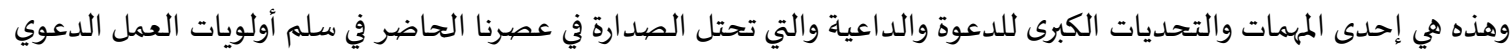

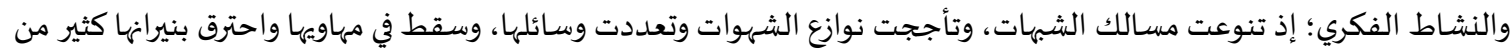

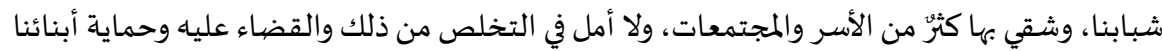

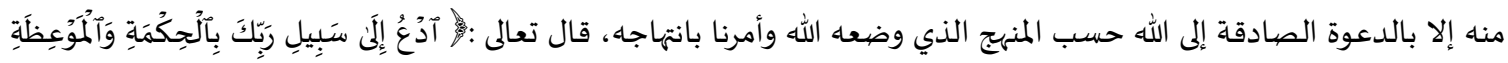

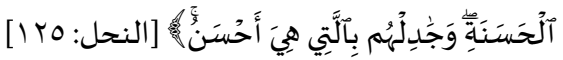

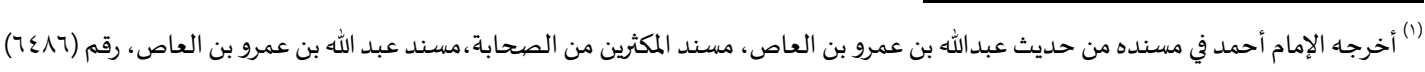

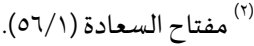

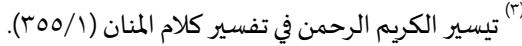

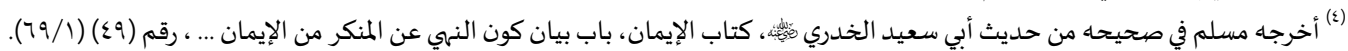

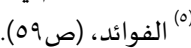

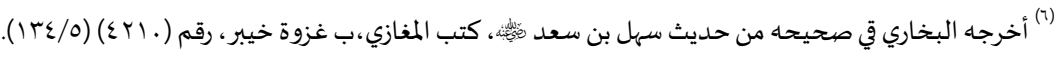



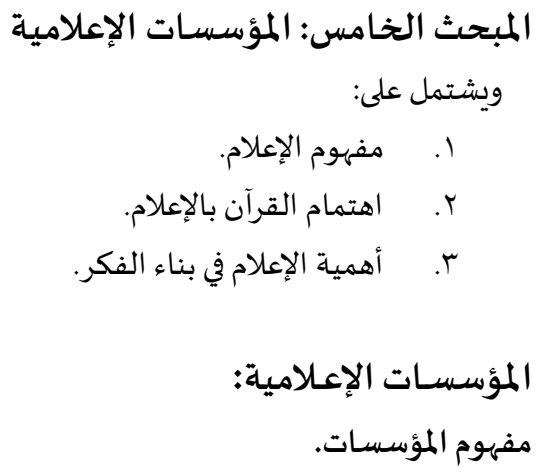

سبق الحديث عنه في اللغة والاصطلاح في مبحث (مصطلحات البحث) عند الحديث عن مصطلح (المؤسسات) بما يغني عن إعادته هنا. مفهوم الإعلام.

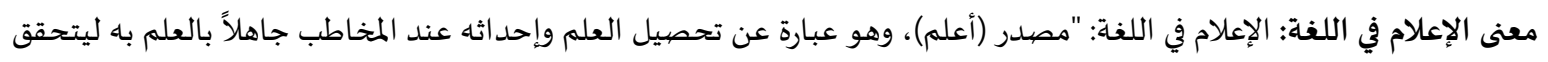

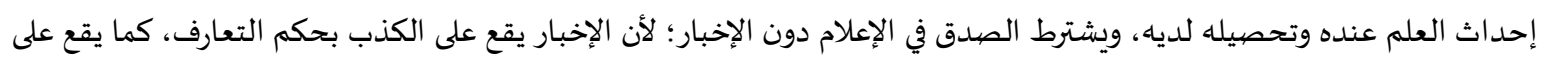

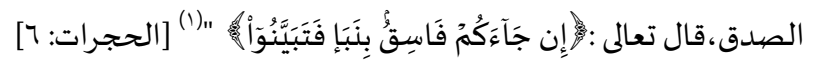
وقال أبو هلال العسكري :"الإعلام: التعريض لِأَنْ يَعْلَمَ الشيََ وقد يكون ذلك بوضيع العلم في القلب؛ لأن الله قد علمنا ما اضطررنا إليه..."

معنى الإعلام في الاصطلاح: الإعلام في الاصطلاح، تتعدد تعريفاته وتختلف من باحث لآخر نظراً لأن (الإعلام) مصطلح جديد لم يتبلور مفهوماه حتى يتمكن الباحثون والمتخصصيون من تعريفه تعريفاً جامعاً مانعاً. ا.فعرفه الدكتور إبراهيم إمام بقوله :"تزويد الناس بالأخبار الصحيحة، والمعلومات السليمة، والحقائق الثابتة التي تساعدهم على تكوين رأي صائب في واقعة من الوقائع أو مشكلة من المشكلات، بحيث يعبر هذا الرأي تعبيراً موضوعياً عن عقلية الجماهير

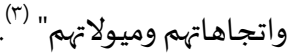
r.وعرفه العالم الألماني (أوتوجورت) بقوله :"الإعلام هو التعبير الموضوعي لعقلية الجماهير ولروحها وميولها واتجاهاتها في نفس الوقت"

"r.وعرفه الدكتور محمود سفر بقوله :"نشر الحقائق والمعلومات الدقيقة الصادقة بهدف التقرير والإقناع" (0). ع.أما الإعلام الإسلامي فقد عرفه الدكتور محتيي الدين عبد الحليم بقوله :"تزويد الجماهير بصففة عامة بحقائق الدين الإسلامي المستمدة من كتاب الله وسنة رسوله، بصورة مباشرة أو غير مباشرة، من خلال وسيلة إعلامية دينية متخصصية أو عامة، بواسطة

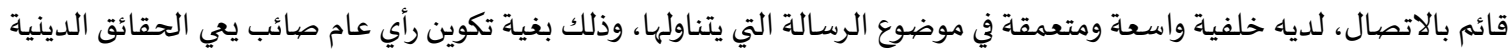

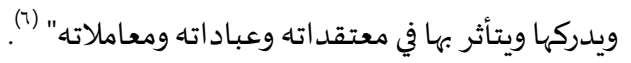
مفهوم مصطلح المؤسسات الإعلامية كمركب وصفي.

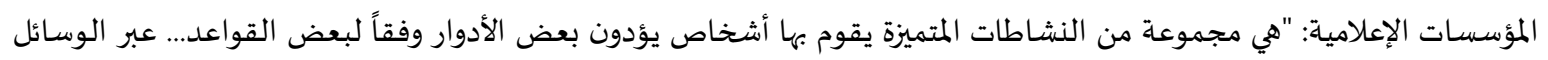
الآتية: ا. الوسائل المقروءة: وتشمل كل ما هو مطبوع مثل: الجريدة، المجلة، الكتاب،...الخ. r. الوسائل المرئية المسموعة: وتشمل التلفزيون، والتسجيلات المرئية الصوتية (فيديو كاست).

$$
\begin{aligned}
& \text { (1) الكليات (معجم في المصطلحات والفروق اللغوية)-أيوب بن موسى الكفوي، (ص1ـ (1). }
\end{aligned}
$$

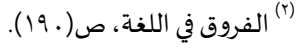

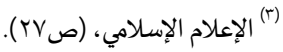

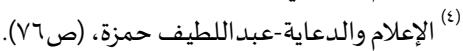

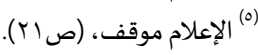

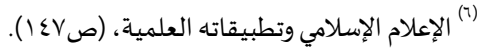


r. الوسائل المسموعة: وتشمل الإذاعة، والتسجيلات الصوتية، كالاسطوانات والاشرطة" (1).

اهتمام القرآن بالإعلام: إم

لقد لفت القرآن الكريم أنظار المسلمين إلى أهمية الإعلام في نشر الإسلام في وقت مبكر من نزوله، بل كان الأمر باستخدام الإعلام لنشر الإسلام من أوائل ما نزل من القرآن الكريم، وهو يشير إليه بمفهومها:

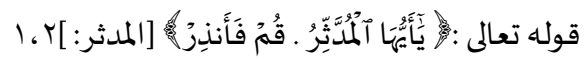

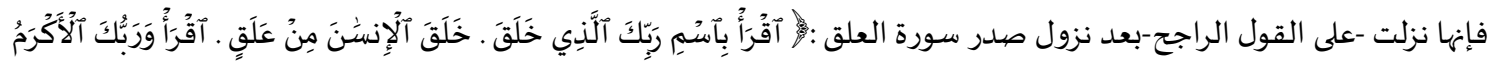

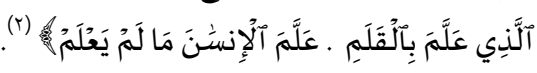

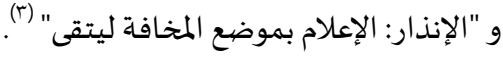

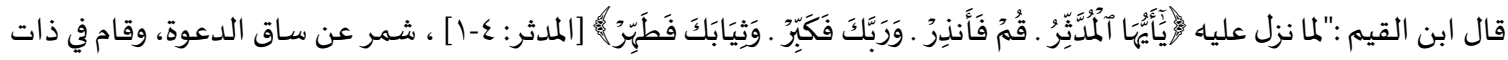

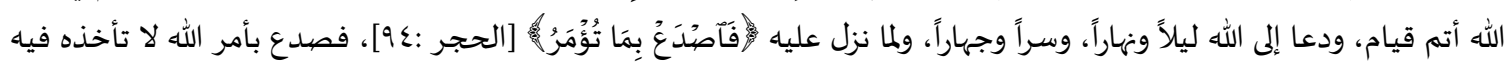

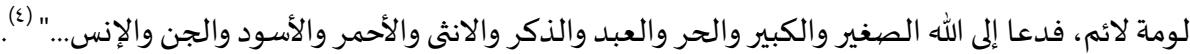

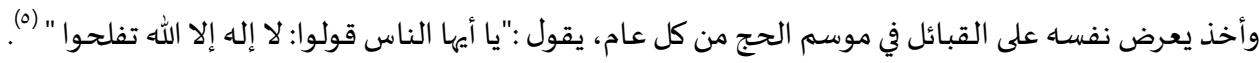

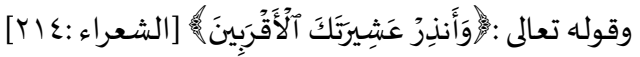

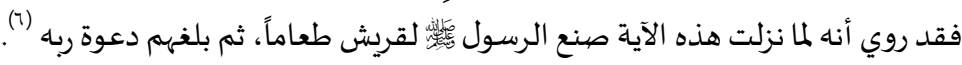

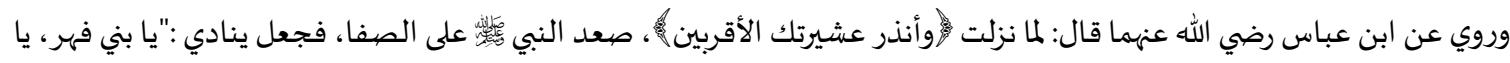

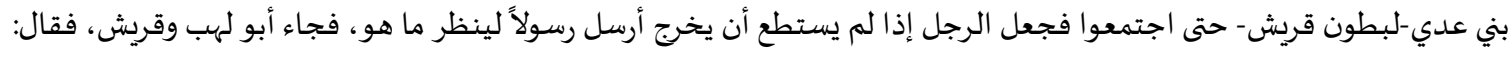

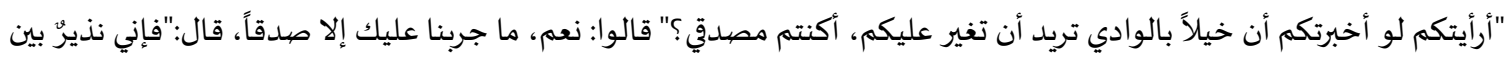

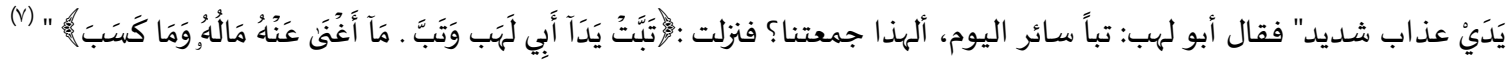

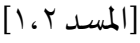

فصناعة الطعام، والصعود على الصفا وسيلتان إعلاميتان حديثتان عامتان جماهيريتان بميزان ذلك العصر لتبليغ دين الله عزوجل

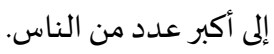

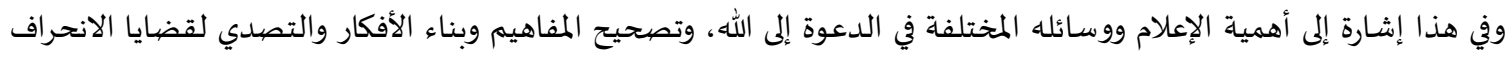

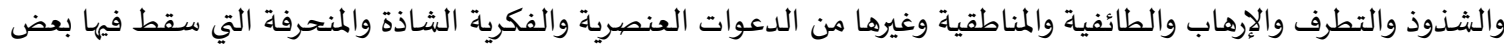

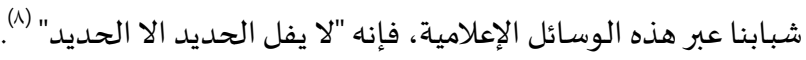

مظاهر اهتمام القرآن بالإعلام. ويمكن إبراز هذا الاهتمام من خلال الوسائل الإعلامية التي شرعت لإعلام الناس والتواصل معهم مثل:

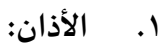

وهو الإعلام بدخول وقت الصلاة (9)

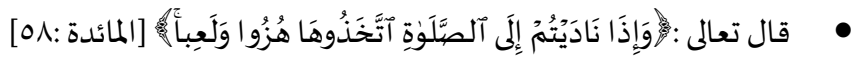

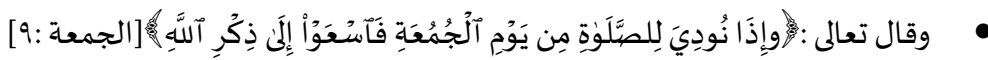

وفي قصة الأذان ما يوحي باهتمام القرآن بالإعلام:

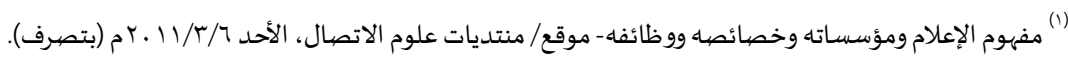

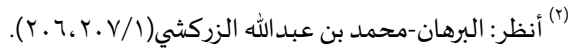

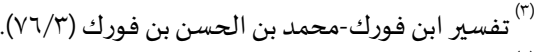

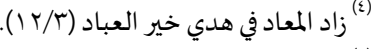

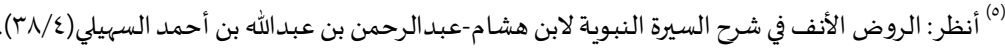

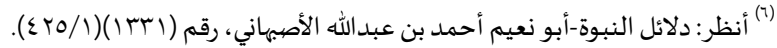

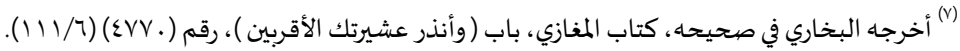

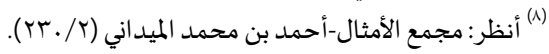

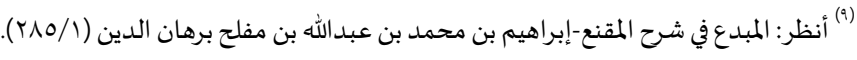

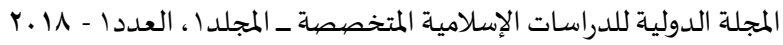




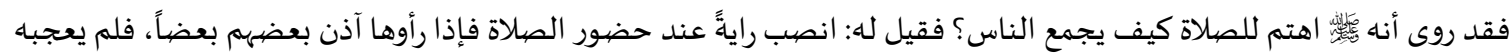

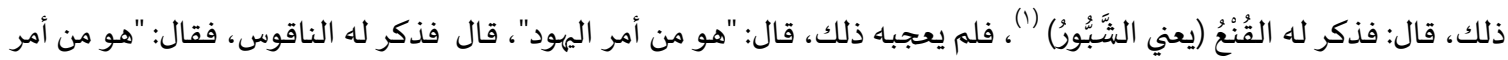

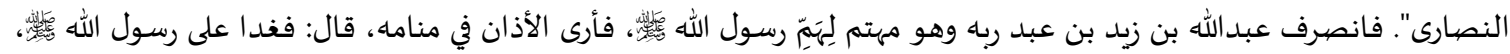

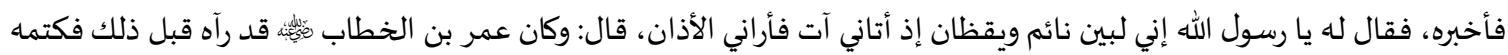

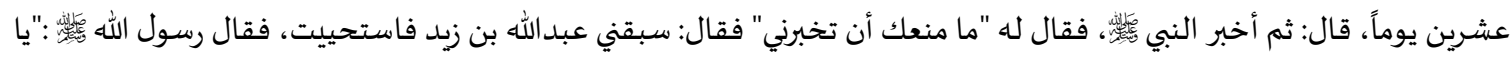

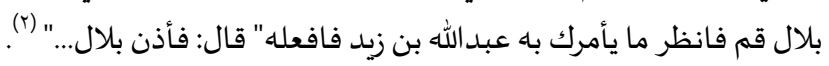

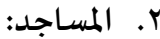

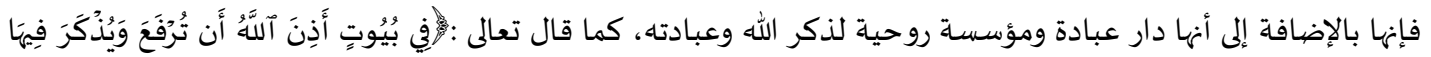

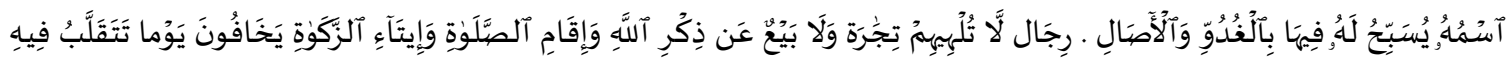

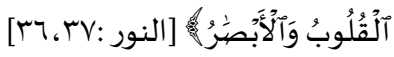

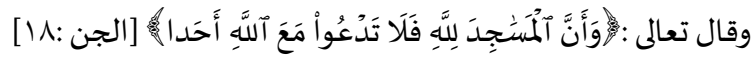

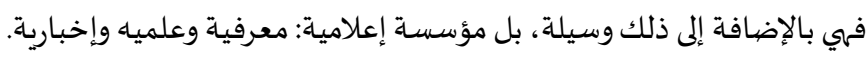
ففي المسجد يتعلم المسلمون ويتثقفون ويتفقهون في دينهم.

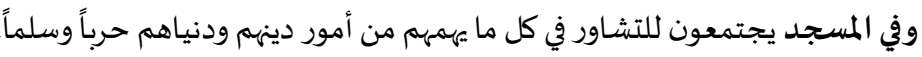

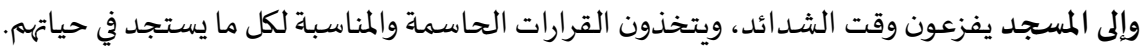

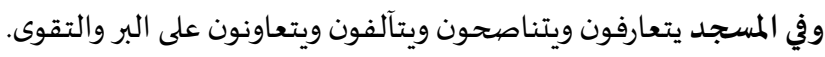

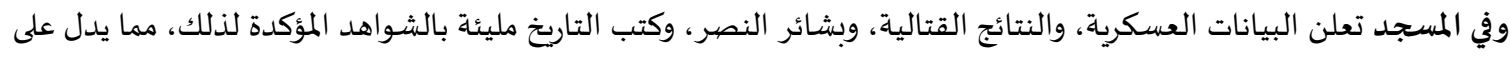

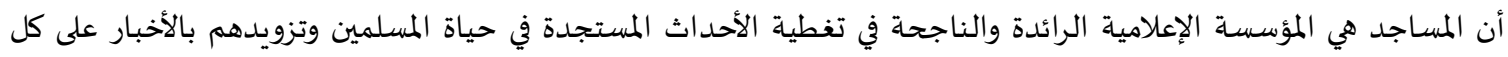

وهو وسيلة إعلامية جماهيرية عامة سواء عبر خطبة الجمعة أو غيرها..

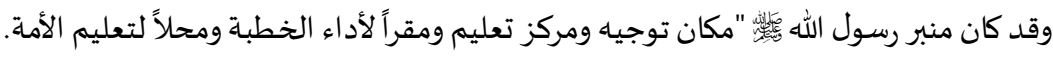

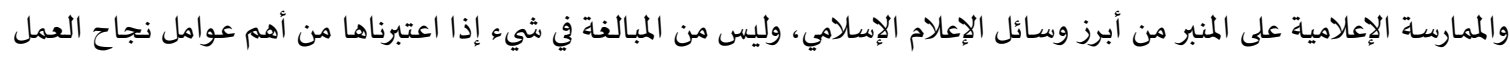

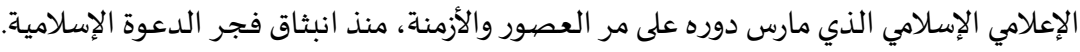

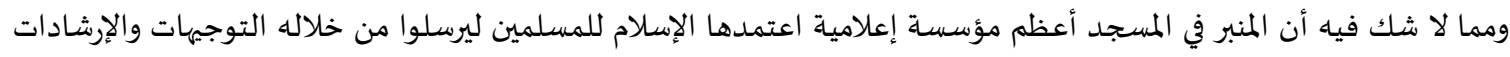

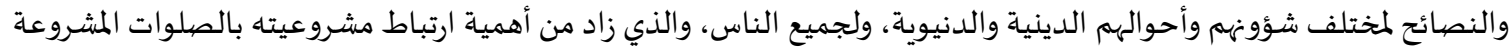

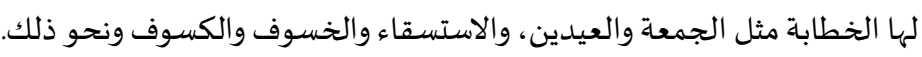
والمعهود من سيرة النبي عليه الصلاة والسلام، أن المنبر أقيم لتوجيه المجتمع في كل شأن من شؤون الناس الكياس الدينية والدنيوية، وفي مختلف المناسبات

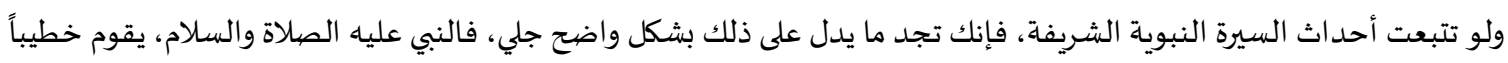

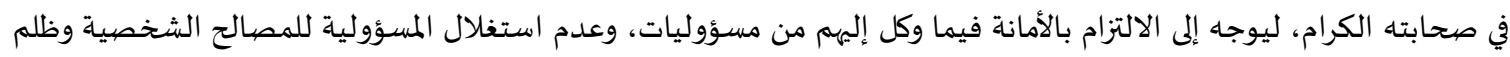

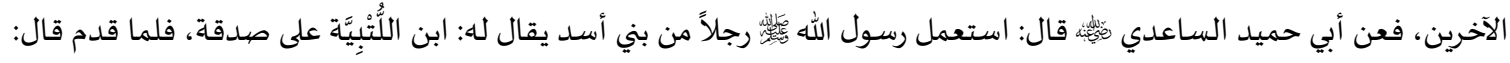

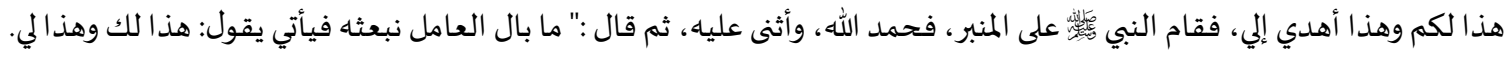

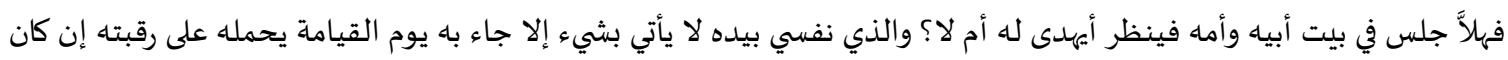

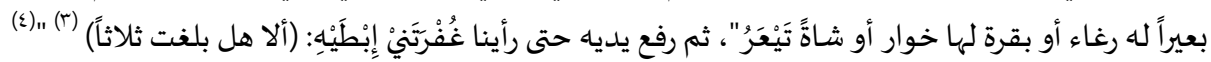

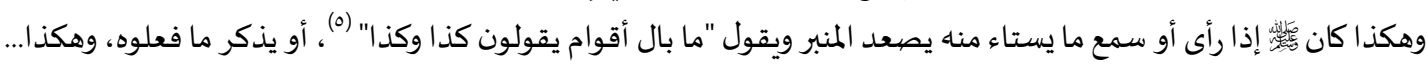

(1) الشبور: هو البوق، لسان العرب-محمد بن مكرم بن علي بن منظور (1/ . . آ).

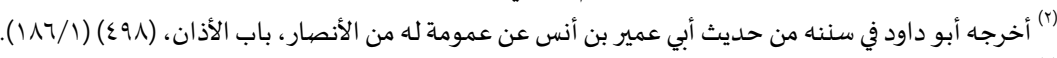

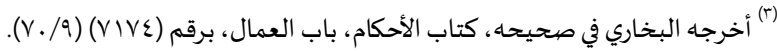

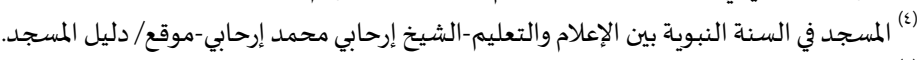

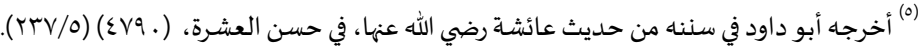




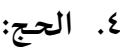

وهو وسيلة إعلامية موسمية سنوية للالتقاء بأكبر عدد من جماهير المسلمين، حيث تتوحد المشاعر والشعائر والقلوب والقوالب.

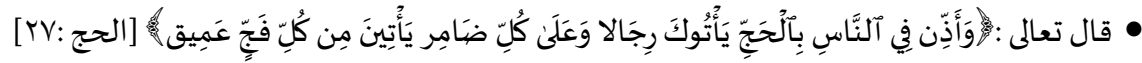

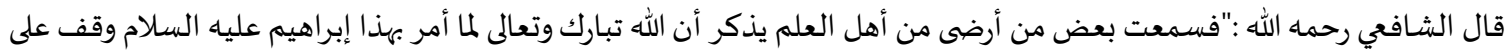

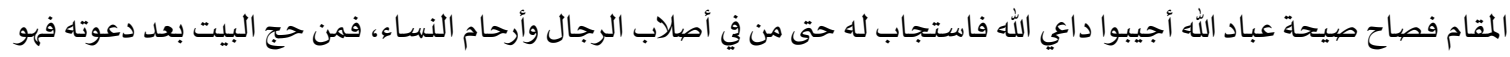

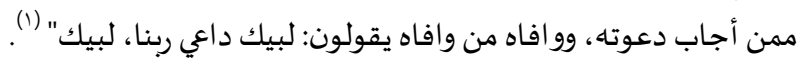

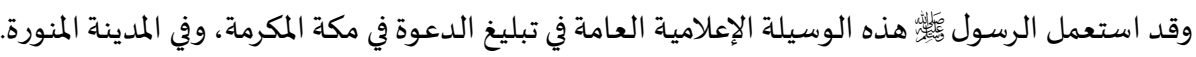
•

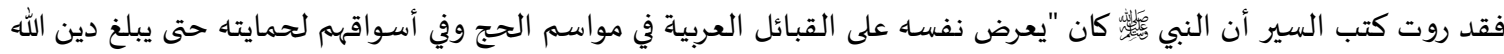

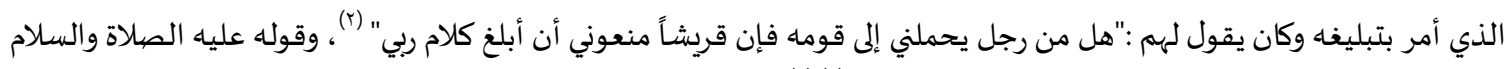

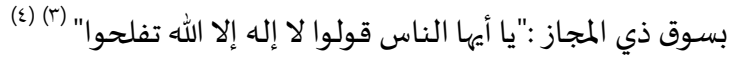
يقول المقريزي :"ثم عرض[أي الرسول دئل

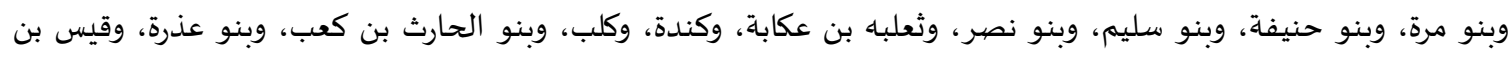

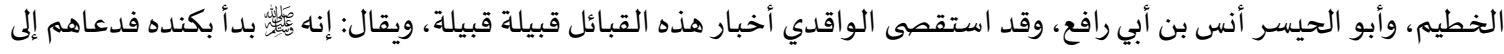

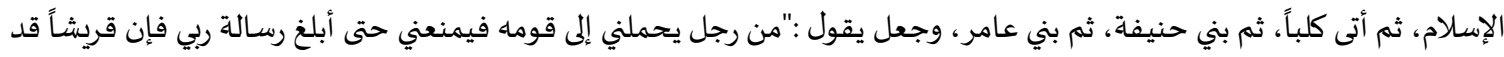
منعوني أن ابلغ رسالة ربي". هذا وعماء أبو لهب وراءه يقول للناس لا تسمعوا منها فإنه كذاب، وكان أحياء العرب يتحامونه لما يسمعون من قريش فياه: إنه كذاب،

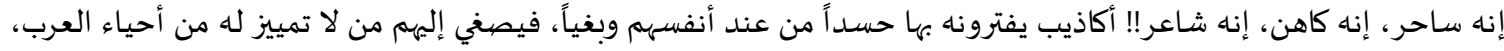

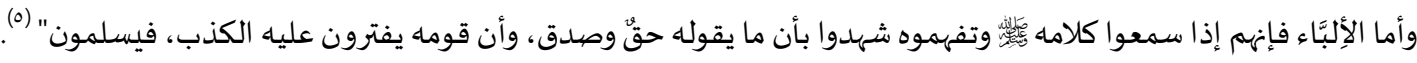
• وأما في المدينة

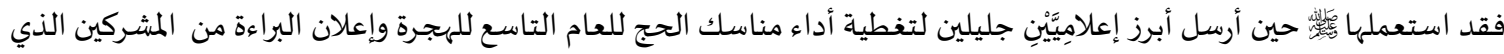
يتضيمنه صدر سورة التوبة وهو:

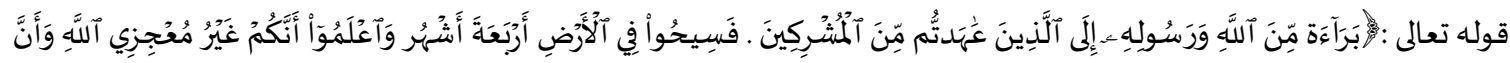

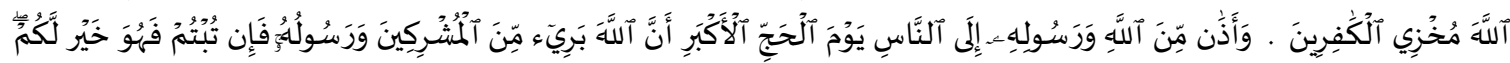

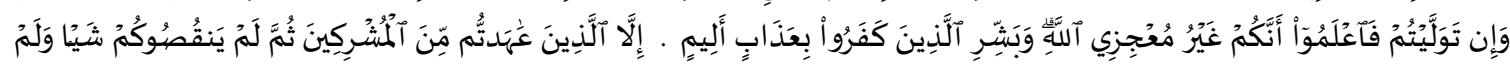

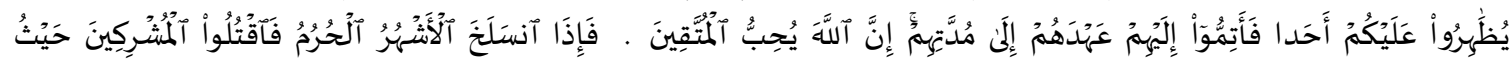

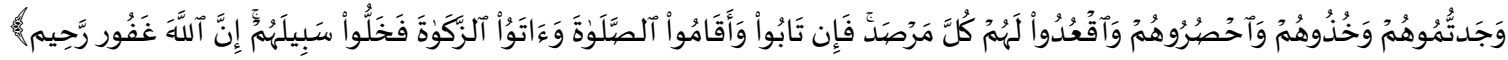

[0-1: التوبة

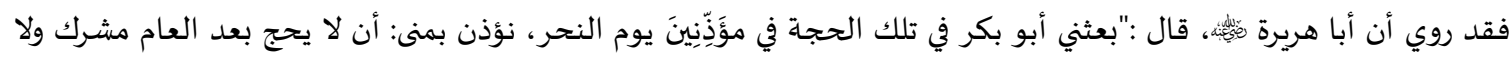

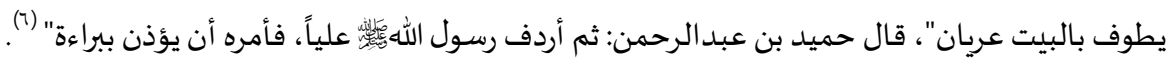

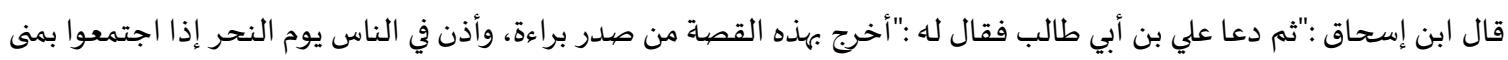

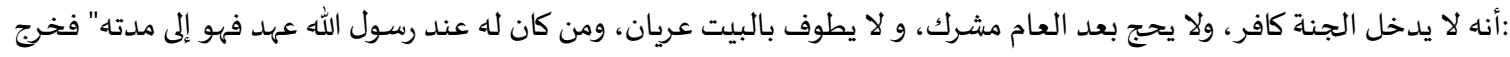

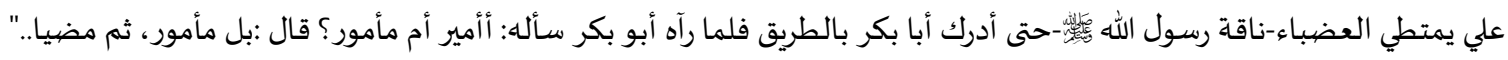

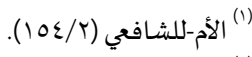

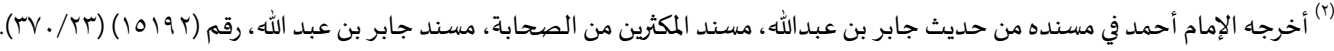

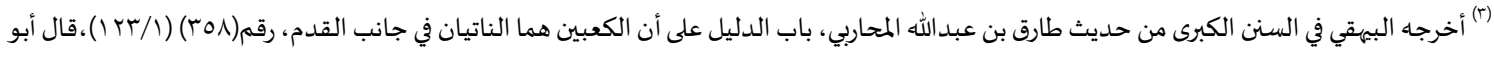

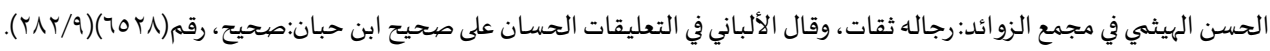

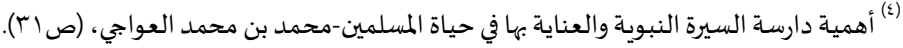

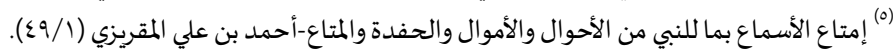

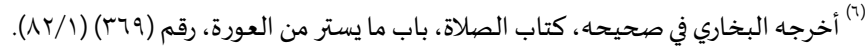




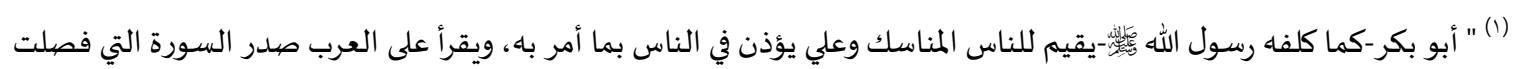
في أمرهم، وأجهزت على الوثنية في بلادهم" (r) . أما ما يفعله الروافض اليوم في موسم الحجر من الفوضى وترويع الحجاج، فلا علاقة له بالبراءة من المشركين، بل هو الشرك بعينه

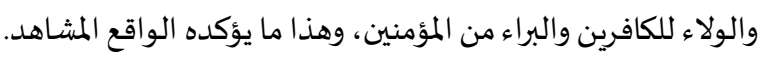

أهمية الإعلام في بناء الفكر: الإعلام سلاح ذو حدين، ازدواجي الفعل والفاعلية، والأثر والتأثير، فكما هو وسيلة للبناء هو كذلك وسيلة للهدم، وكما هو وسيلة للخير هو كذلك وسيلة للشر. الإعلام اليوم يعد السلطة الرابعة بعد السلطة التشريعية والقضيائية والتنفيذية.

$$
\begin{aligned}
& \text { الإعلام يصنع الرأي العام ويوجه الجماهير. } \\
& \text { • الإعلام يبني العقل ويصيخ الفكر ويشكل الرأي. } \\
& \text { • الإعلام أصبح اليوم مصدر المعرفة والعلم والفكر لجمهور الناس وعامتهم. } \\
& \text { الإعلام وسيلة فاعلة للترويج لأي فكر ونجاحه. } \\
& \text { الإعلام وسيلة جماهيرية لنشر المعلومات والأخبار. } \\
& \text { الإعلام وسيلة للتسويق والإقناع السياسي والفكري وغيرهما. } \\
& \text { • الإعلام وسيلة جماهيرية للتثقيف والتوجياه. } \\
& \text { الإعلام وسيلة جماهيرية للترفيه والترويح. } \\
& \text { الإعلام وسيلة جماهيرية لنشر القيم والأخلاق، والعادات والتقاليد الإيجابية والسلبية. }
\end{aligned}
$$$$
\text { الإعلام وسيلة جماهيرية للتعبير عن قضايا وهموم الشعوب. }
$$

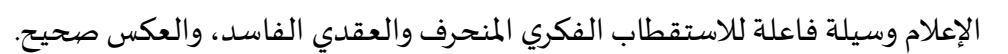

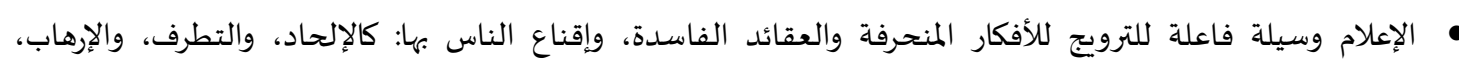

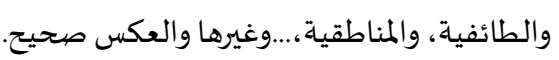$$
\text { • أصبح الإعلام الوسيلة الوحيدة لتلقي المعلومات الإخباربة المعرفية لدى الغالبية الساحقة من الناس. }
$$$$
\text { • أصبح الإعلام أهم وأخطر الوسائل في تشكيل سلوك الفرد والجماعة وتحديده وتوجيهاه. }
$$$$
\text { • أصبح الإعلام الوسيلة الوحيدة للتثقيف لدى الغالبية العظمى من الناس. }
$$

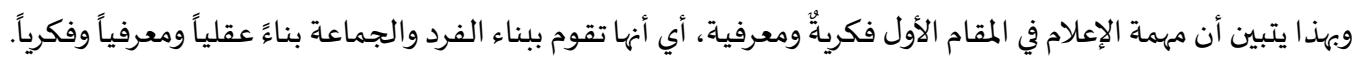

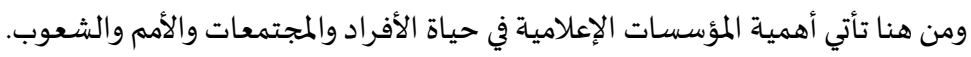

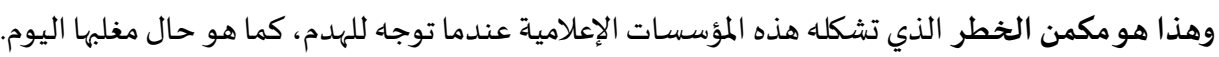

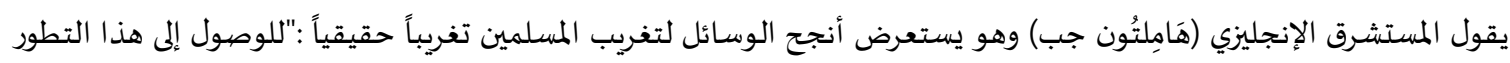

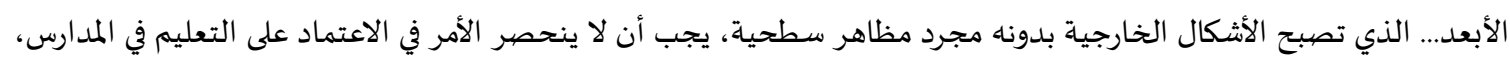

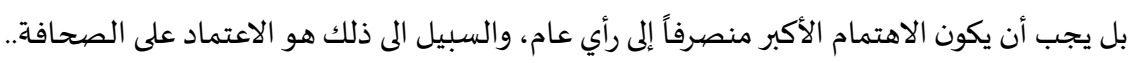

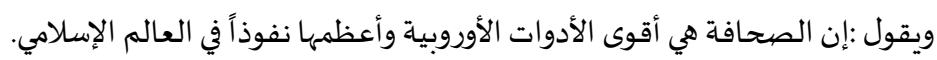
ويستطرد قائلاً: إن النشاط التعليمي والثقافي- عن طريق المدارس العصيرية والصحافة- قد ترك في المسلمين-من غير وعي منهم- أثراً جعلهم يبدون في مظهرهم العام لادينيين إلى حد بعيد...

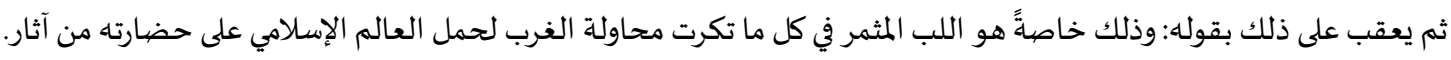

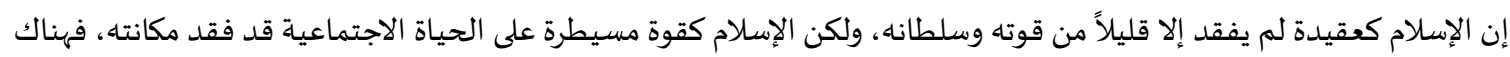

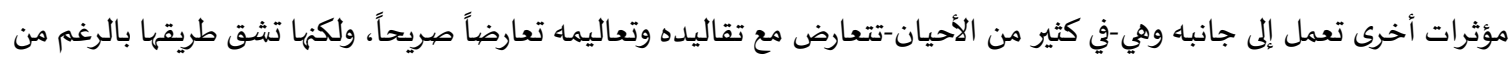

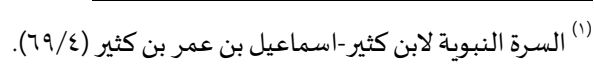

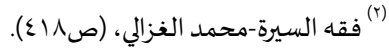


ذلك إلى المجتمع الإسلامي في قوة وعزم... وبذلك فقد الإسلام سيطرته على حياة المسلمين الاجتماعية وأخذت دائرة نفوذه تضيق شيئًا

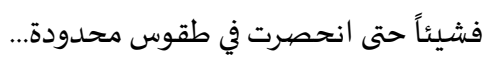

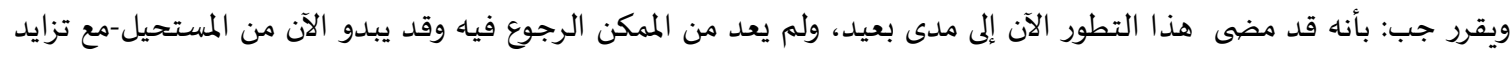

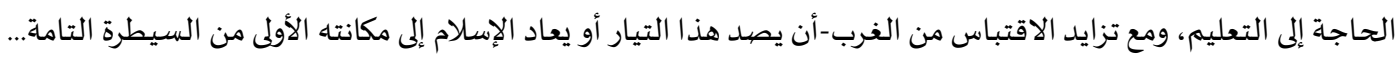

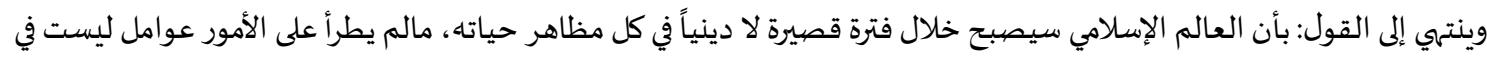

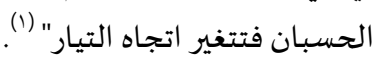

ومن هنا تأتي أهمية الإعلام في بناء الفكروتحصين العقل التحبي وتتجلى في المهام الآتية: (r)

ا. تجديد الدعوة إلى التوحيد، وهذه الدعوة لا تعني أن التوحيد غير موجود، بل هو تذكير مستمر ينبغي أن يركز عليه الداعية الإعلامي دائماً.

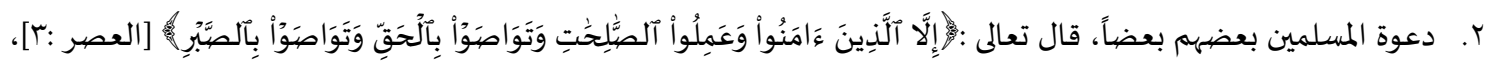

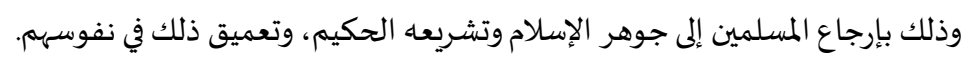

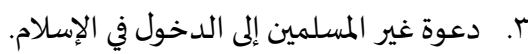

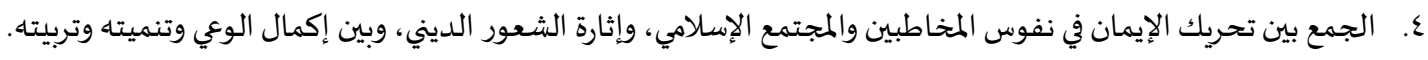

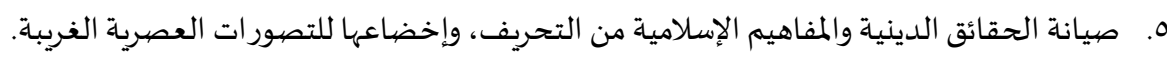

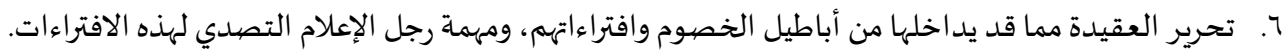

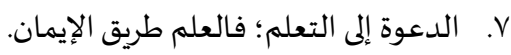

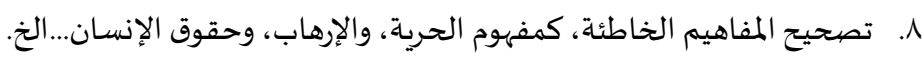

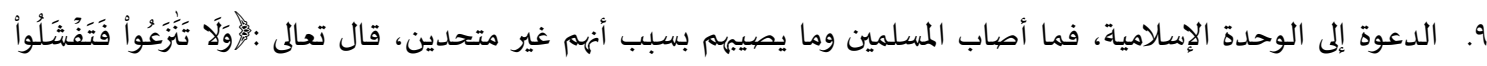

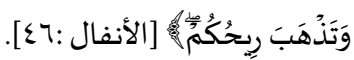

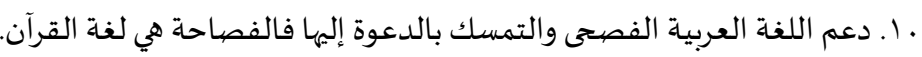
11. إ. بعث الفكر الأصيل والتماس منابعها في القرآن والسنة.

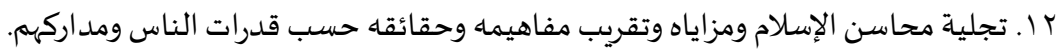

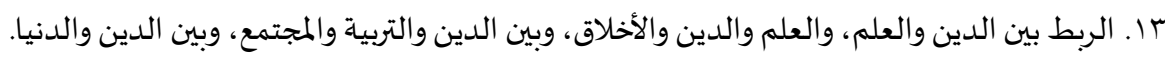
ع ا. بث القيم والأخلاق والفضائل والعادات الإسلامية السليمة. 10 أ الاهتمام بالجانب الترفيهي الهادف على قاعدة (ساعة وساعة) (r)

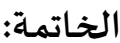

تم بحمد الله وتوفيقه الفراغ من هذا البحث ( مؤسسات البناء الفكري في ضوء القرآن الكريم ) وقد جاء في مقدمة، وتمهيد، وخمسة مباحث، وخاتمة. أما المقدمة، فقد قدمت فيها وخها تصوراً أولياً لطبيعة البحث، وعرضت فيها أسباب اختيار البحث، وأهدافه، والمنهج المستعمل في كتابته،

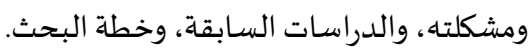

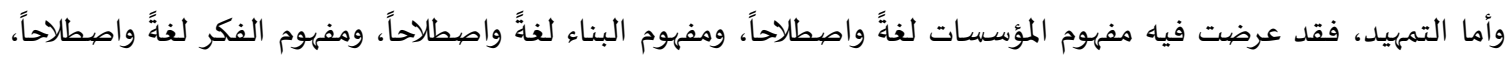
ومفهوم البناء الفكري كمصطلح مركب تركيباً وصفياً.

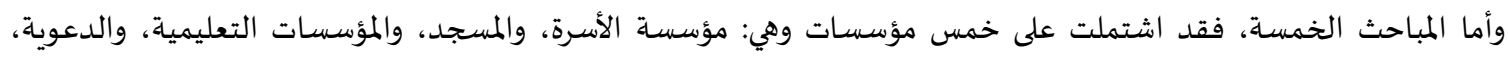

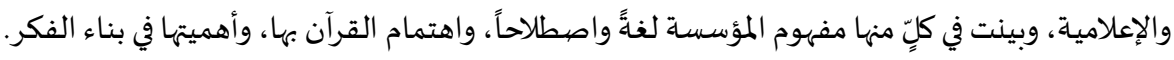

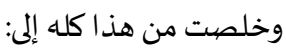
• • (أن للفكر في الإسلام مؤسساتٍ يجب تفعيلها.

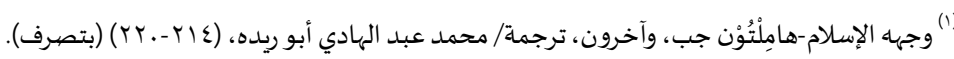

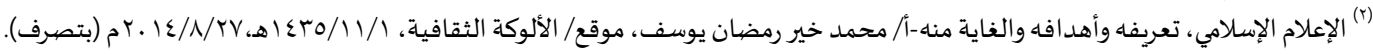

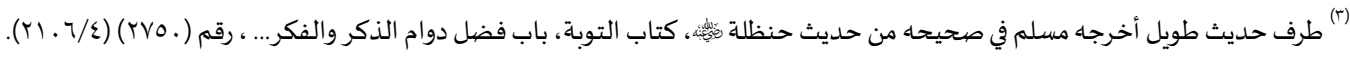


• وأن بناء المسلم بناءً فكرياً من أوائل القضايا - إن لم تكن الأولى - التي اهتم بها الإسلم ودعا إلهها في أول ما نزل من القرآن على الإطلاق.

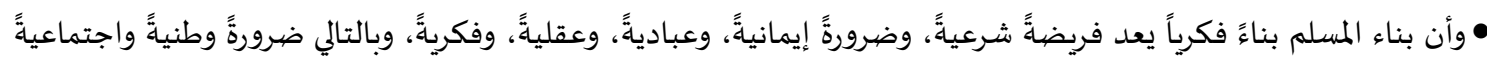

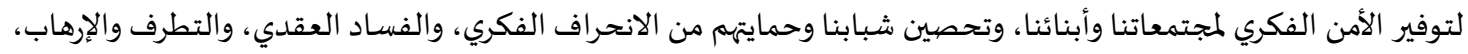
والتعصب الطائفي والمناطقي، ومن الغزو الثقافي العارم عموماً. التوصيات: وختاماً يوصي الباحث بما يأتي: 1. أ تفعيل المؤسسات الفكرية وتوجيهيا للبناء الفكري ومواجهة الانحراف.

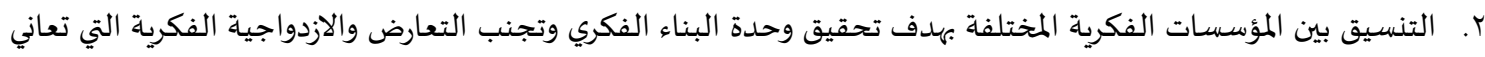
منها هذه المؤسسات. r. ت تثوير القرآن الكريم للتصدي للقضايا الفكرية المختلفة ومعالجتها. وصهلى الله على سيدنا محمد وعلى آله وصحبه وسلم المغلم

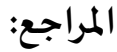
1. الإبانة الكبرى: عبيد الله بن محمد بن بطة العكبري، تحقيق/رضا معطي، وآخرون، دار الراية. الرياض.

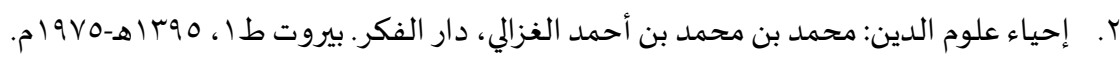

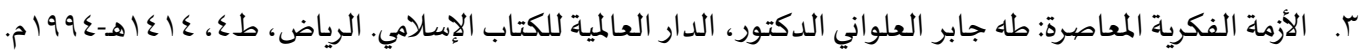

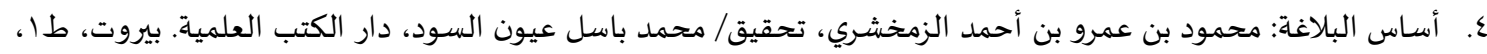

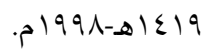

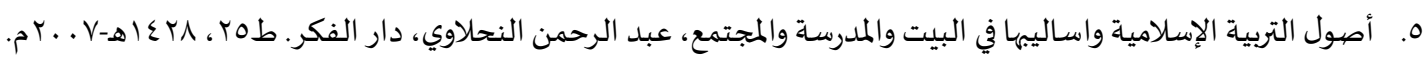

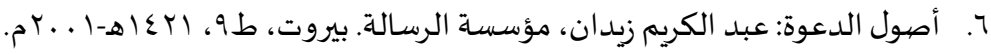

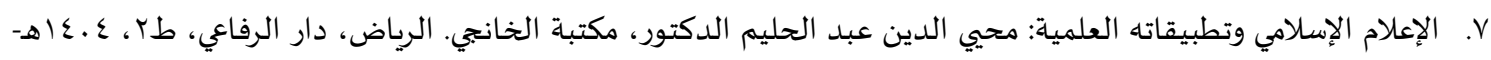

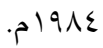

1. الإعلام الإسلامي: إبراهيم إمام الدكتور، مكتبة الأنجلو المصرية. القاهرة، طا ، ـ19 ام. م. 9.

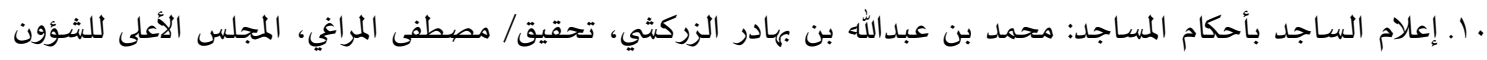

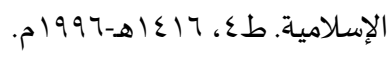

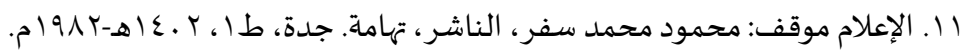

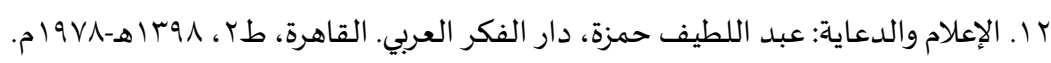

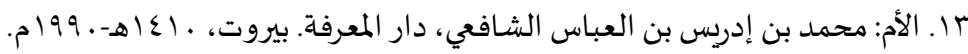

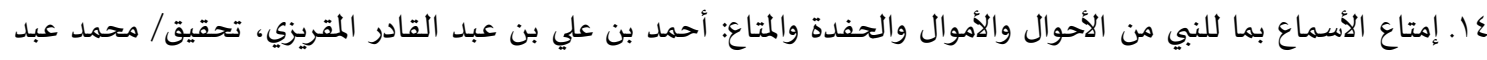

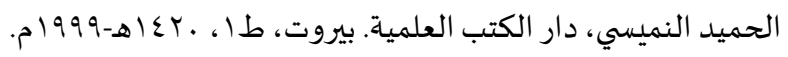

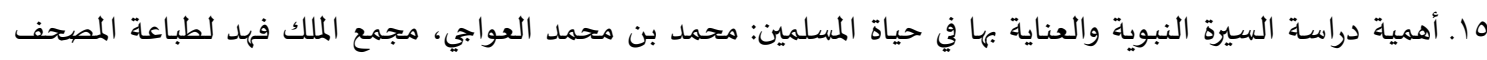
الشريف.

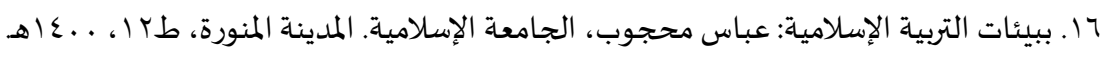

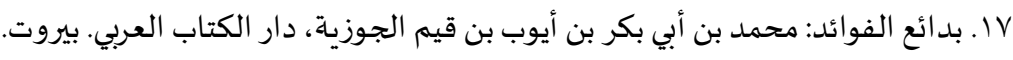

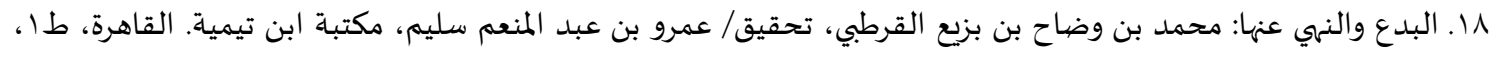

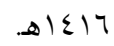
19 ا. البرهان في علوم القرآن: محمد بن عبدالله بن بهادر الزركشي، تحقيق/ محمد أبو الفضل إبراهيم، دار إحياء الكتب العربية،

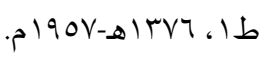

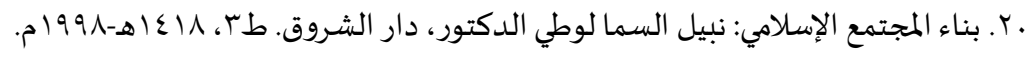


آ البيت السعيد وخلاف الزوجين: صالح بن عبد الله بن حميد، وزارة الشؤون الإسلامية والأوقاف والدعوة والإرشاد. r r. تاج العروس: محمد بن محمد مرتضى الزبيدي، دار الهداية. بr. تخريج أحاديث الكشاف للزمخشري: عبدالله بن يوسف الزيلعي، تحقيق/ عبدالله بن عبدالـالرحمن السعد، دار ابن خزيمة.

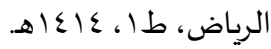
ع r. تعريف المؤسسة التعليمية: هبة كامل، موقع/ موضوعوع أكبر موقع عربي بالعالم.

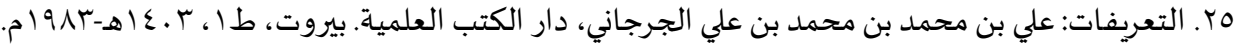

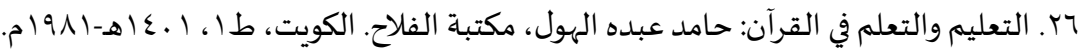

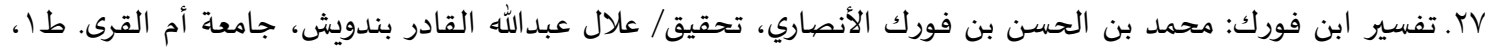

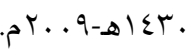

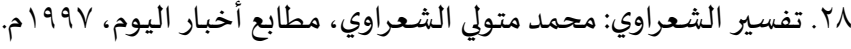

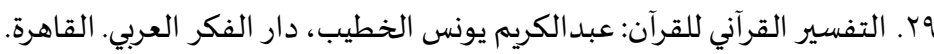
•r. التفسير القيم (ابن القيم): محمد بن أبي بكر بن أيوب بن قيم الجوزية، تحقيق/ مكتب الدراسات والبحوث العربية

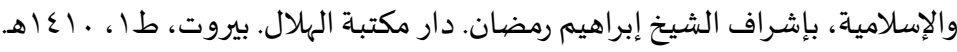

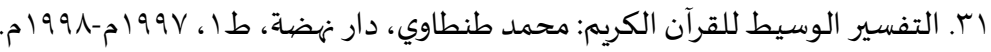

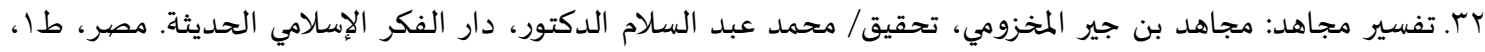

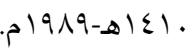

بr. تنظيم الإسلام للمجتمع: محمد أبو زهرة، دار الفكر العربي. القاهرة، 1970 أم.

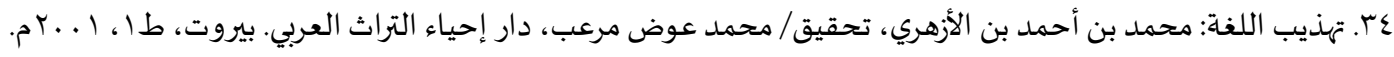
هr. التوقيف على مهمات التعاريف: محمد المدعو بعبدالرؤوف بن تاج العارفين المناوي، عالم الكتب. القاهرة، طا ، . إعاهـ . 199 .

جس. تيسير الكريم الرحمن في تفسير كلام المنان: عبد الرحمن بن ناصر بن عبدالله السعدي، تحقيق/عبد الرحمن بن معلا

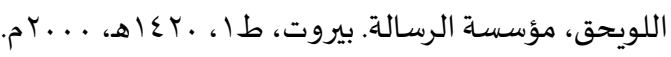

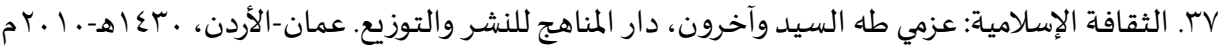

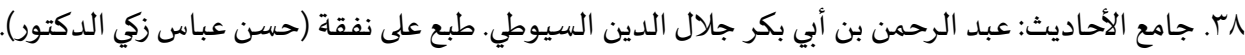

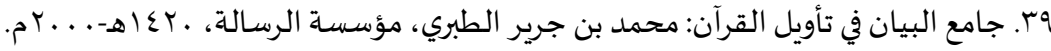

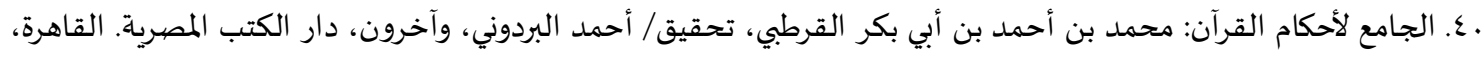

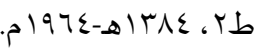
اع. جمهرة الأمثال: الحسن بن عبد الله بن سهل العسكري، دار الفكر. بيروت.

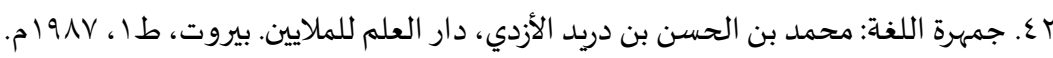

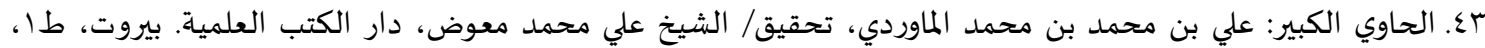

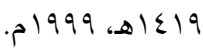

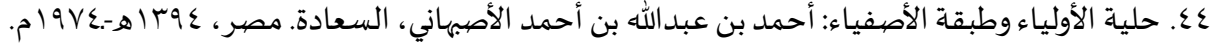

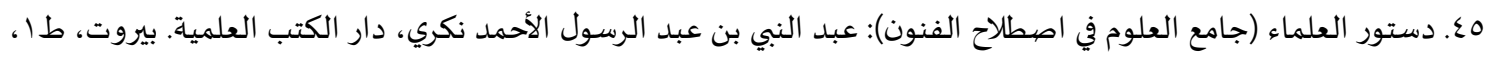
م

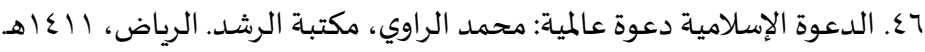

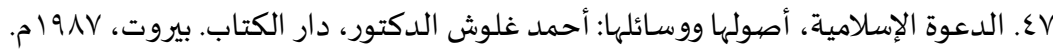

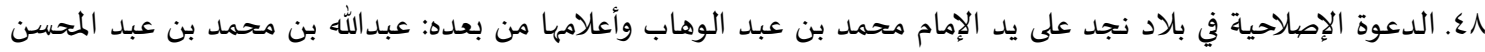

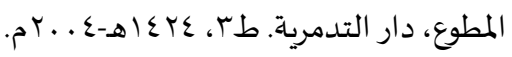
9ع. دلائل النبوة لأبي نعيم: أحمد بن عبدالله بن أحمد الأصبهاني، تحقيق/ محمد رواس قلعها جي، وآخرون، دار النفائس. بيروت،

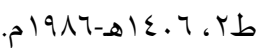
• ه. دلائل النبوة: أحمد بن الحسين بن علي بن موسى البيهقي، دار الكتب العلمية. بيروت. 
10. دور الأسرة في إعداد القائد الصغير: هاني السيد العزب، المجموعة العربية للتدريب والنشر، 10 ــrم.

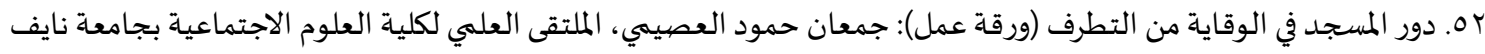

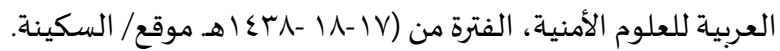

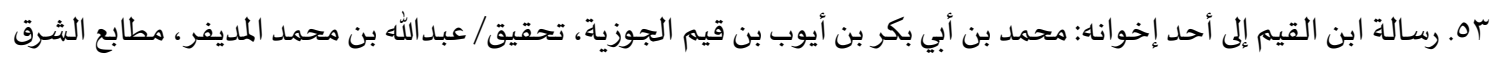

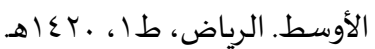
عه. الروض الأنف في شرح السيرة النبوية لابن هشام: عبدالرحمن بن عبدالله بن أحمد السهيلي، تحقيق-اعمر عبدالسلام

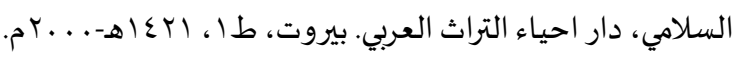

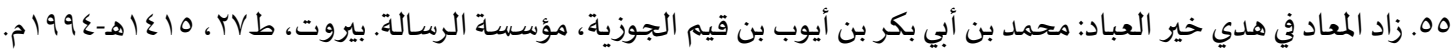

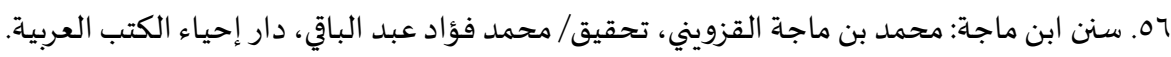

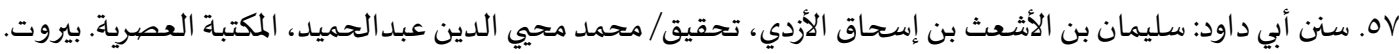

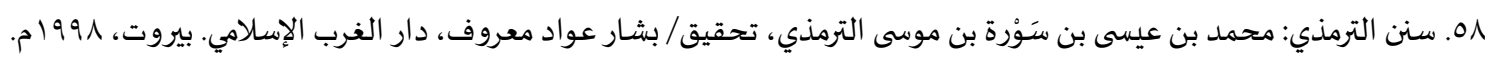

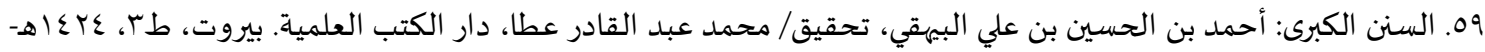
.

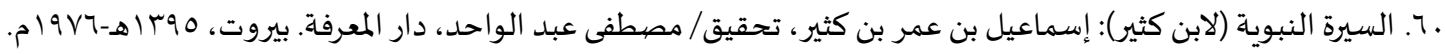

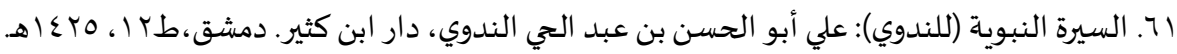

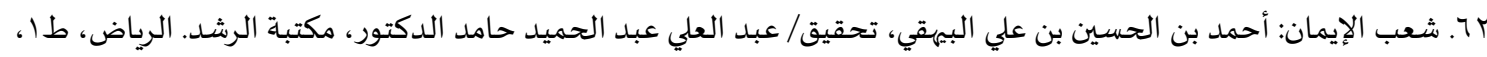

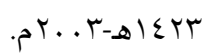

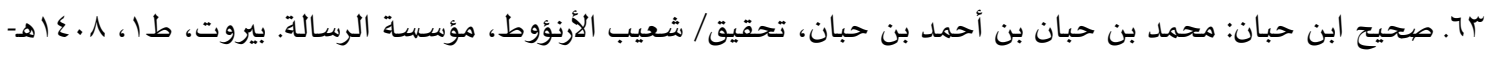
.01911

ع7. صحيح ابن خزيمة: محمد بن إسحاق بن خزيمة، تحقيق/ محمد مصطفى الأعظمي الدكتور، المكتب الإسلامي. بيروت.

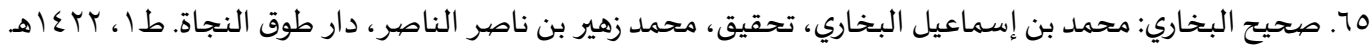

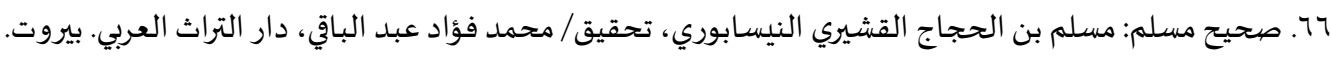

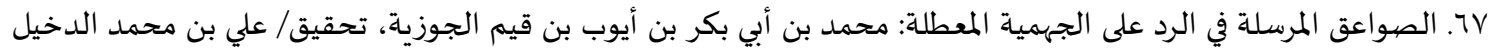

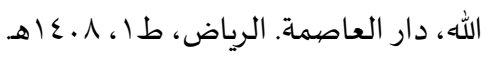

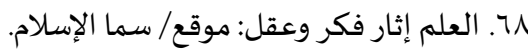

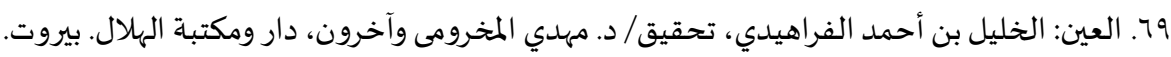

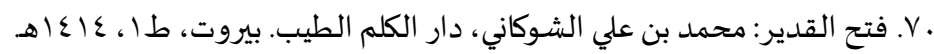
الV. الفروق اللغوية: الحسن بن عبد الله بن سهل العسكري، تحقيق/ محمد إبراهيم سليم، دار العلم والثقافة. القاهرة.

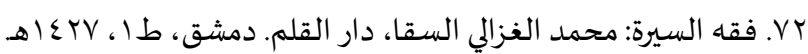

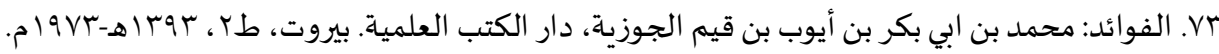

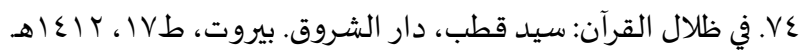

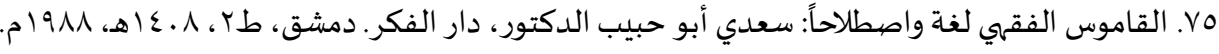

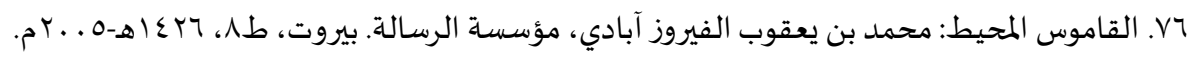

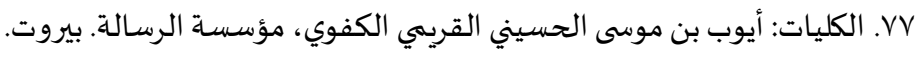
VA

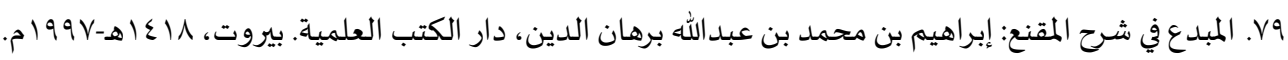
•. 1. مجلة إسلامية المعرفة-المعهد العالمي للفكر الإسلامي: عممان، الأردن. ا بـ. مجلة المنار الثقافية الدولية الالكترونية.

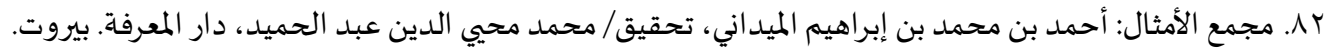

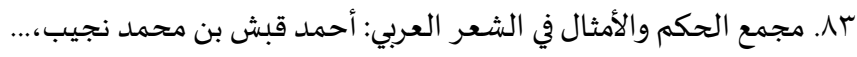


عـ. مجمع بحار الأنوار في غرائب التنزيل ولطائف الأخبار: محمد طاهر بن علي الصديقي، مطبعة دائرة المعارف العثمانية. حيدر

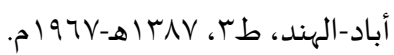

مر. مجموع الفتاوى: أحمد بن عبد الحليم بن تيمياة، تحقيق/ عبد الرحمن بن محمد بن قاسم، مجمع الملك فهد لطباعة المصحف

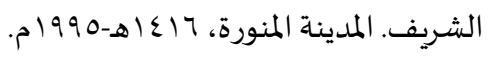

11. مجموع فتاوى العلامة ابن باز: عبد العزيز بن عبدالله بن باز، أشرف على جمعاه وطبعه / محمد بن سعد الشـويعر.

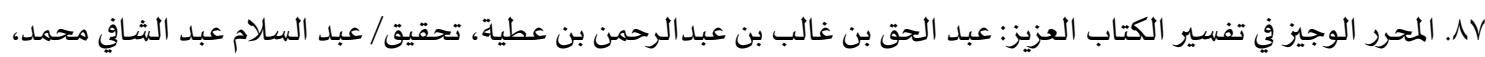

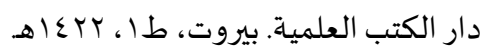

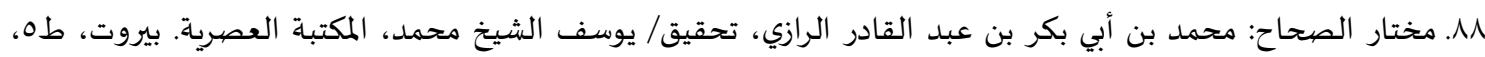

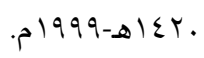

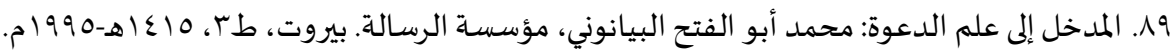
9. 9.

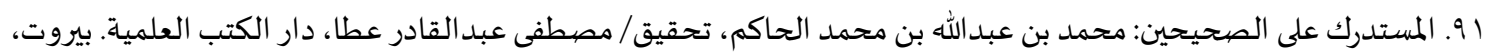
ط

rq. المسجد في السنة النبوية بين الإعلام والتعليم: الشيخ إرحابي محمد إرحابي، موقع/ دليل المسجد.

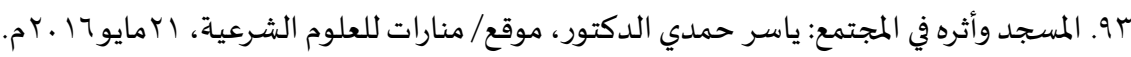
ع 9.

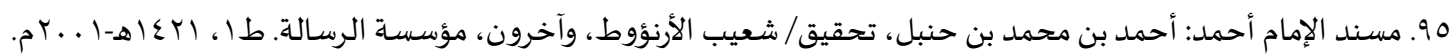

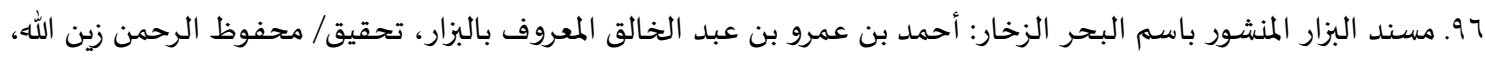

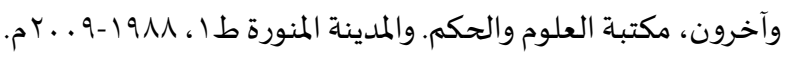

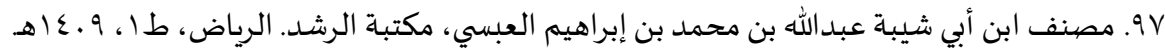
19. المعجم الأوسط: سليمان بن أحمد بن أيوب الطبراني، تحقيق/ طارق بن عوض عاد الله بن بن محمد، وآخرون، دار الحرمين. القاهرة. 99. . . . . معجم الفروق اللغوية: الحسن بن عبدالله بن سهل العسكري، تحقيق وترتيب/ بيت الله بيات، مؤسسة النشر الإسلامي. طـ

ا ـ ا. المعجم الكبير: سليمان بن أحمد بن أيوب الطبراني، تحقيق/حمدي بن عبد المجيد السلفي- مكتبة ابن تيمية القاهرة، طب.

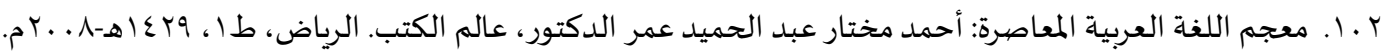

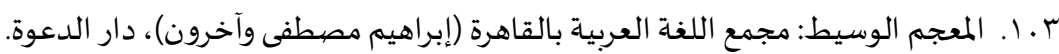

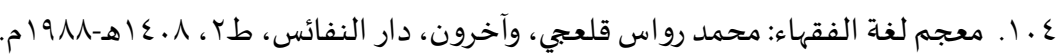

0

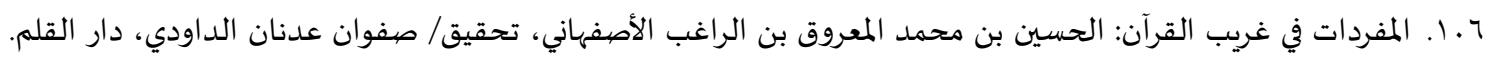

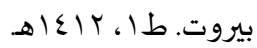

V. ا. مفهوم الإعلام ومؤسساته وخصائصيه ووظائفه: موقع/ منتديات علوم الاتصال.

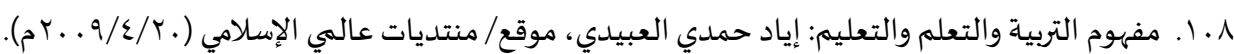

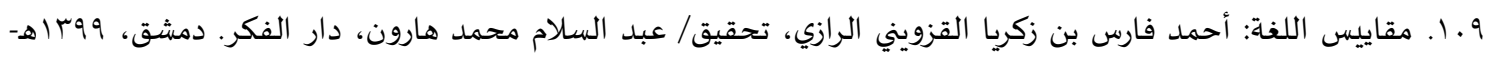

. $19 \vee 9$ • 11. مقدمات للنهوض بالعمل الدعوي: عبد الكريم بكار، دار القلم. دمشق. 111 rال. النهاية في غريب الحديث والأثر: مجد الدين أبو السعادات بن محمد بن الأثير، تحقيق/طاهر أحمد الزاوي، وآخرون، المكتبة

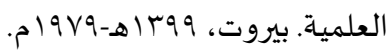

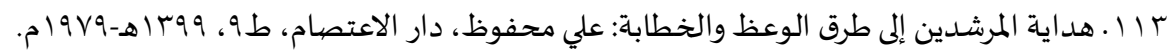




\title{
يميى هممد عاهز راشد \\ هؤسسات البناء الفكري في ضوء القرآن الكريم \\ Refaad \\ المجلة الدولية للدراسات الإسلامية المتخصصية

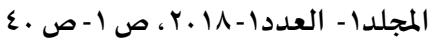 \\ رفاد للدراسـات والأبحاث \\ https://doi.org/DOI:10.31559/sis2018.1.1.1 \\ www.refaad.com \\ The Institutions of Intellectual Construction in the Light of the Holy Quran
}

\author{
Yahya Mohammed Amer Rashed \\ King Khalid University- College of Sharia and Fundamentals of Religion- \\ Department of Quran and Sciences- Kingdom of Saudi Arabia \\ yahya19622@gmail.com
}

\begin{abstract}
:
This research (the institutions of intellectual construction in the light of the Holy Quran) included an introduction, a preface, and five questions, a conclusion.

As for the introduction, it provided a visual perception of the nature of the research, and was presented during the selection of the subject of research, its importance, its objectives ,,, its Verdath, problem, previous studies, and research plan.

As for the extension, it presented the concept of linguistic and scientific institutions, the concept of construction, unity and the word.

The five mabahiths are: the family, the mosque, the educational institutions, the da'wa, the media, and the façade in its entirety

And concluded from all this that the thought in Islam institutions must be activated, and that the building of the Muslim intellectual construction of the exploits.

The Muslim has built the intellectual behind his struggle, his passion, his passion, his curiosity, his tears, his family, his drabness, and vice versa.
\end{abstract}

Keywords: Institutions of Intellectual Construction, intellectual wars. 